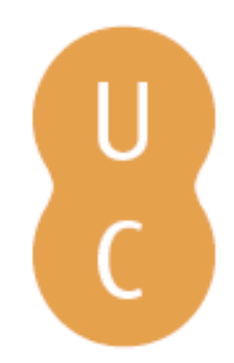

\title{
pommalina
}

\section{A globalização no mundo antigo: do polites ao kosmopolites}

Autor(es): Leão, Delfim Ferreira

Publicado por: Imprensa da Universidade de Coimbra

URL

persistente: URI:http://hdl.handle.net/10316.2/5668

DOI: $\quad$ DOI:http://dx.doi.org/10.14195/978-989-26-0267-7

Accessed : $\quad$ 26-Apr-2023 11:19:20

A navegação consulta e descarregamento dos títulos inseridos nas Bibliotecas Digitais UC Digitalis, UC Pombalina e UC Impactum, pressupõem a aceitação plena e sem reservas dos Termos e Condições de Uso destas Bibliotecas Digitais, disponíveis em https://digitalis.uc.pt/pt-pt/termos.

Conforme exposto nos referidos Termos e Condições de Uso, o descarregamento de títulos de acesso restrito requer uma licença válida de autorização devendo o utilizador aceder ao(s) documento(s) a partir de um endereço de IP da instituição detentora da supramencionada licença.

Ao utilizador é apenas permitido o descarregamento para uso pessoal, pelo que o emprego do(s) título(s) descarregado(s) para outro fim, designadamente comercial, carece de autorização do respetivo autor ou editor da obra.

Na medida em que todas as obras da UC Digitalis se encontram protegidas pelo Código do Direito de Autor e Direitos Conexos e demais legislação aplicável, toda a cópia, parcial ou total, deste documento, nos casos em que é legalmente admitida, deverá conter ou fazer-se acompanhar por este aviso.

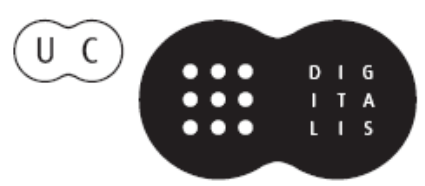




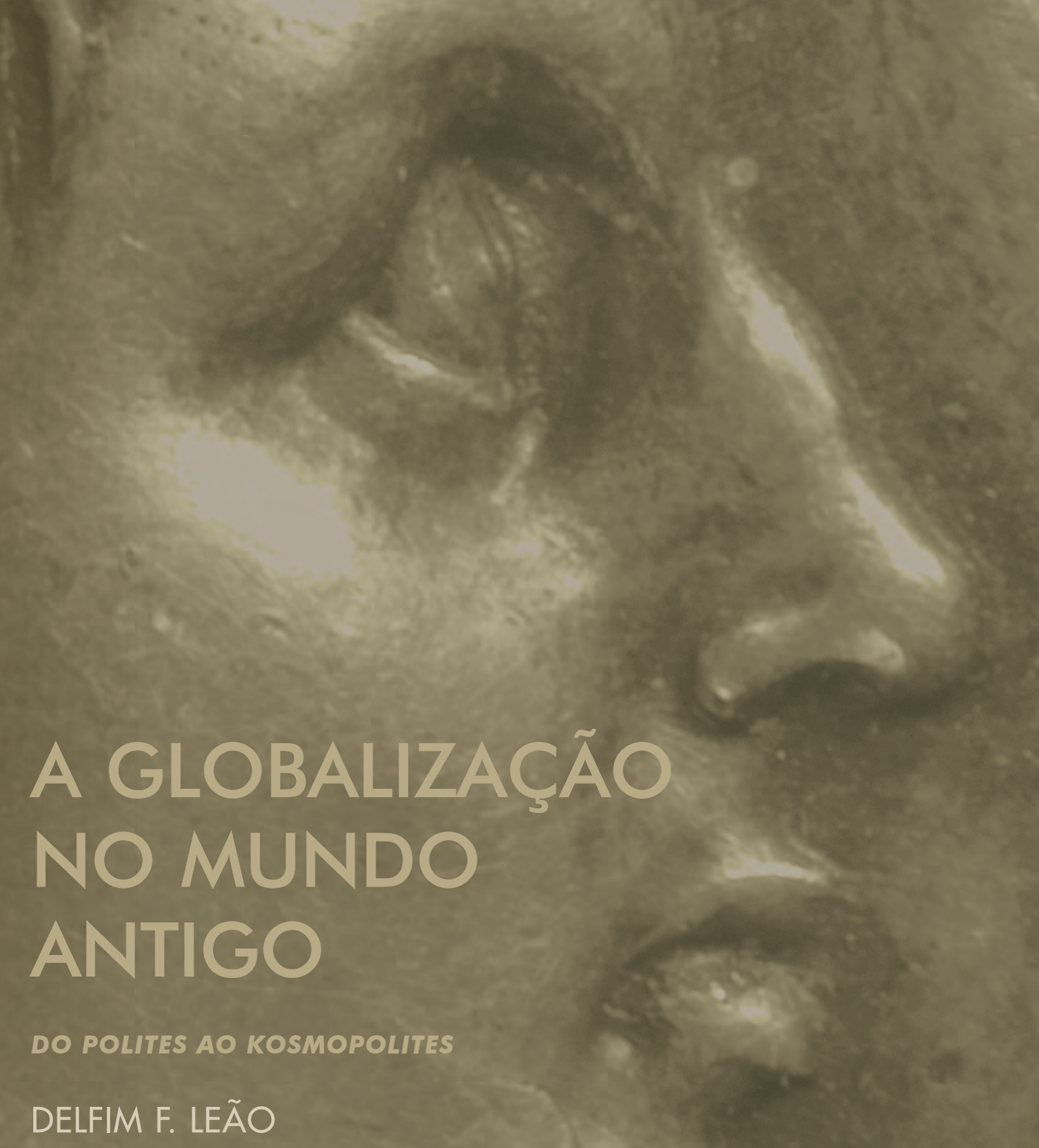

DELFIM F. LEÃO

IMPRENSA DA UNIVERSIDADE DE COIMBRA

COIMBRA UNIVERSITY PRESS 
(Página deixada propositadamente em branco) 
奀

$\frac{\mathrm{I}}{\mathrm{U}}$ 


\title{
EDIÇÃO
}

Imprensa da Universidade de Coimbra

URL: http://www.uc.pt/imprensa_uc

Email: imprensauc@ci.uc.pt

Vendas online: http://www.livrariadaimprensa.com

\author{
CONCEÇÃO GRÁFICA \\ António Barros
INFOGRAFIA DA CAPA
Carlos Costa

INFOGRAFIA

Xavier Gonçalves

EXECUÇÃO GRÁFICA

www.artipol.net

ISBN

978-989-26-0267-7

ISBN Digital

978-989-26-0267-7

DOI

http://

dx.doi.org/10.14195/978-989-26-0929-4

DEPÓSITO LEGAL

$345806 / 12$

OBRA PUBLICADA COM O APOIO DE:

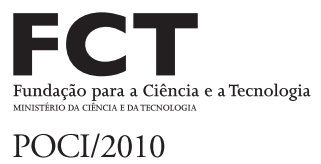

C) JUNHO 2012, IMPRENSA DA UNIVERSIDADE DE COIMBRA 


\section{A GLOBALIZAÇÃO NO MUNDO ANTIGO}

DO POLITES AO KOSMOPOLITES DELFIM F. LEÃO 
(Página deixada propositadamente em branco) 
À memória de meu pai, José Ferreira Leão, modelo de honradez e dedicação ao trabalho. 
(Página deixada propositadamente em branco) 


\section{SUMÁRIO}

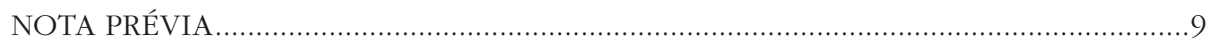

1. ENQUADRAMENTO GERAL: DO POLITES AO KOSMOPOLITES .............................. 15

1.1. Pólis: a formação do polites para o exercício da cidadania .................................... 15

1.1.1. As Guerras Medo-persas e o imperialismo ático ............................................ 17

1.1.2. A Guerra do Peloponeso e os golpes contra a democracia ..........................18

1.1.3. Séc. Iv: as crises de liderança e o declínio da pólis ......................................22

1.2. Os reinos helenísticos: do polites ao kosmopolites ..................................... 23

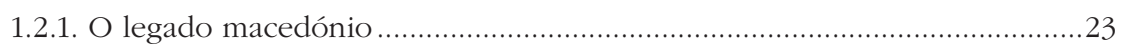

1.2.2. Os Diádocos e a criação das monarquias helenísticas ...............................2 25

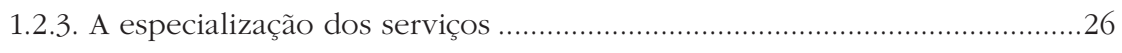

1.2.4. Os limites de atuação das póleis helenísticas ..............................................28

2. LICURGO: O MÍTICO CRIADOR DA CONSTITUIÇÃO ESPARTANA …........................33

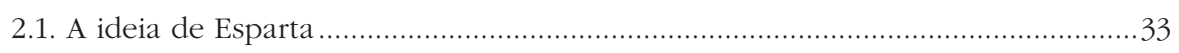

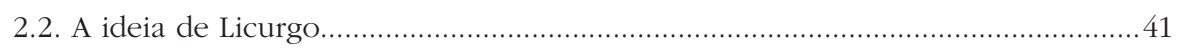

3. IDEOLOGIA E IMPÉRIO: O TEMA DA AUTOCTONIA

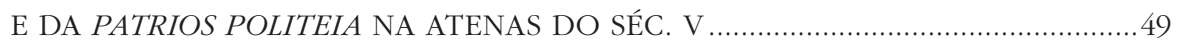

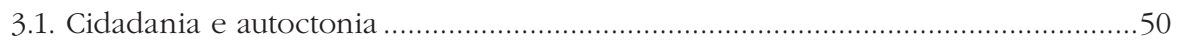

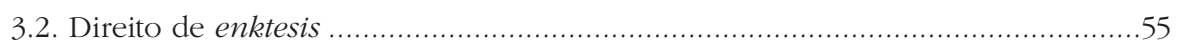

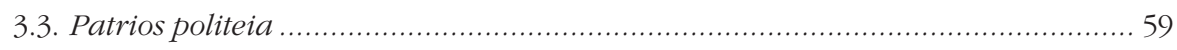

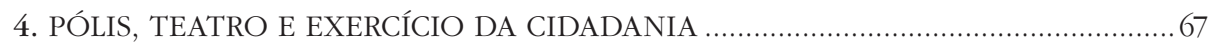

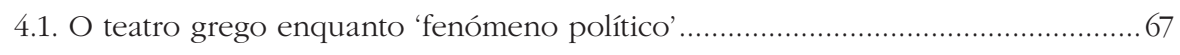

4.2. O processo de financiamento dos festivais de teatro........................................70

4.3. Horizonte cívico e horizonte dramático ........................................................ 74

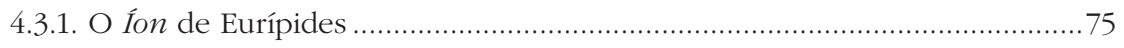


5. POLITES, IDIOTES, KOSMOPOLITES: A ATENAS DE FÓCION .85

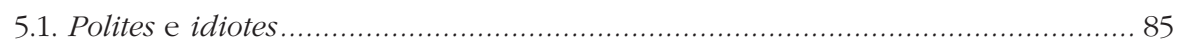

5.2. Fócion: o último polites e os novos idiotai ................................................... 88

5.2.1. Sucessos militares e ascensão política de Fócion ........................................89

5.2.2. O último dos politai: o fim de Fócion ......................................................93

6. ALEXANDRE MAGNO: DA ESTRATÉGIA PAN-HELÉNICA AO COSMOPOLITISMO ……................................................... 97

6.1. Alexandre: história, biografia e amplificação lendária ........................................97

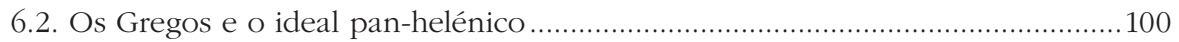

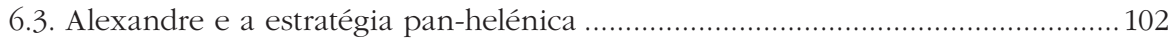

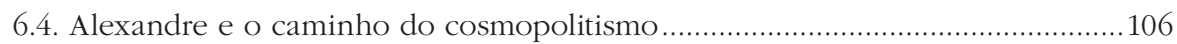

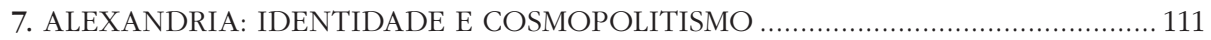

7.1. O cânone das Sete Maravilhas da antiguidade: o farol de Alexandria ................. 111

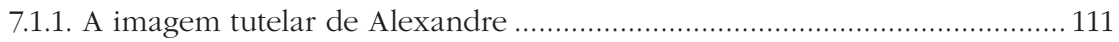

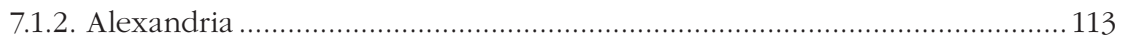

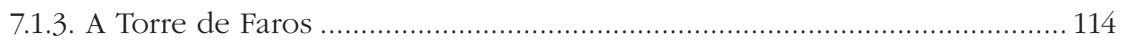

7.2. O politeuma judaico de Alexandria ............................................................... 118

8. PAULO DE TARSO E A JUSTIÇA DOS HOMENS: HELENISMO E IMPIEDADE RELIGIOSA NOS ATOS DOS APÓSTOLOS ......................................129

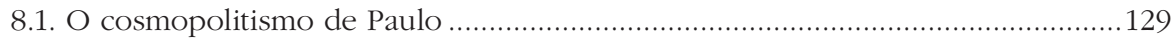

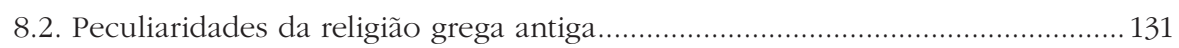

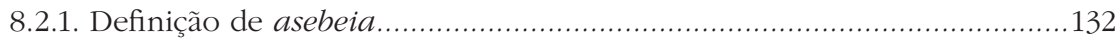

8.3. Paulo em Filipos, Corinto e Atenas ............................................................... 138

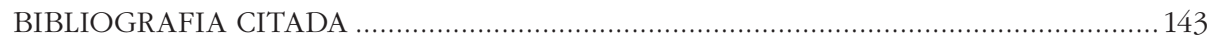

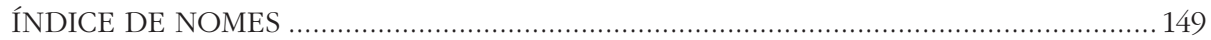

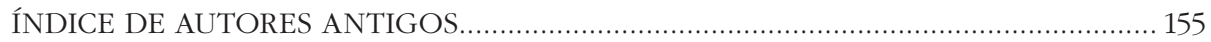




\section{NOTA PRÉVIA}

A ideia de escrever um livro que abordasse a forma como a vivência da cidadania acompanhou a passagem do particularismo da pólis ou cidade-estado grega para o ambiente globalizado dos reinos helenísticos conheceu a primeira expressão concreta numa comunicação apresentada pelo autor na Universidade Nova de Lisboa, em outubro de 2006, precisamente sobre o tema "Do polites ao kosmopolites". Esse primeiro ensaio viria não só a ser expandido através de um estudo homónimo mais amplo, publicado em 2009, no Anuario de Estudios Filológicos, como motivaria várias exposições em contexto académico - a última das quais ocorreu num curso ministrado na Alemanha, na Universidade de Siegen (7 a 11 de março de 2011), sobre o tópico "From the polites to the kosmopolites: the experience of globalization in the ancient world", integrado no programa Erasmus "Myths, nation-building, political identities". Entretanto, o plano de escrever um volume sobre esta matéria sairia reforçado pelo facto de a Unidade de Investigação em que o autor está integrado (o Centro de Estudos Clássicos e Humanísticos da Universidade de Coimbra) ter definido como projeto plurianual o binómio Pólis / Cosmópolis — identidades locais e identidades globais.

O presente volume deriva, por conseguinte, desta conjugação de fatores e nele conflui o resultado de uma série de estudos desenvolvidos, essencialmente, ao longo dos últimos seis anos, estando em parte já publicados e em parte ainda inéditos. Independentemente do contexto inicial de produção de algumas dessas abordagens prévias, as reflexões que agora se apresentam foram sujeitas, na íntegra, a um profundo processo de reescrita, com o intuito de harmonizar o conjunto e de garantir uma abordagem integrada e orgânica dos diferentes temas 
discutidos. Desse trabalho resultou um conjunto de oito capítulos, articulados entre si, cujas linhas gerais se resumem de seguida.

1. "Enquadramento geral: do polites ao kosmopolites": este estudo inicial procura sintetizar, de forma programática, o fundo político, económico e social que marcou a passagem da cidade-estado grega para a realidade mais ampla dos reinos helenísticos. Do empenho num compromisso coletivo (ta politika), que remetia para segundo plano os anseios pessoais (ta idia), passou-se a privilegiar a busca da felicidade individual - não tanto porque a grandeza de pessoas singulares não se conseguisse acomodar nas calhas estreitas das obrigações sociais, mas antes porque a fraqueza da sociedade deixara de motivar o indivíduo particular (idiotes), libertando-o para o anonimato de um circuito de mobilidade mais vasto. Do polites se evoluía assim para o kosmopolites, do carácter local da cidade-estado para o mundo globalizado da oikoumene.

2. "Licurgo: o mítico criador da constituição espartana": uma longa tradição fazia de Licurgo o fundador da constituição espartana, atribuindo-lhe assim a criação de um conjunto de preceitos que norteariam, durante séculos, a vida política e militar de uma das mais marcantes póleis gregas. Esse documento fundacional - conhecido por "Grande Rhetra" — será, mais provavelmente, produto do contributo dado por vários estadistas, e sobre o seu tradicional criador repousa inclusive, desde a antiguidade, a suspeita legítima de que poderia não ter tido existência real. Pesem embora estas dúvidas, é inevitável, em qualquer abordagem da história de Esparta, a consideração da figura de Licurgo, cujos contornos míticos se confundem, de resto, com a própria idealização a que a sociedade espartana foi sujeita, também desde muito cedo. Licurgo constitui, de facto, um elucidativo exemplo da forma como a factualidade histórica pode ser amplificada de maneira a melhor servir determinada ideologia, incarnada pela figura de heróis fundadores, numa expressão paradigmática da identificação total entre a pólis e o polites.

3. "Ideologia e império: o tema da autoctonia e da patrios politeia na Atenas do séc. v": o mito da autoctonia e a ideologia da patrios politeia espelham, de forma elucidativa, dois momentos marcantes da história de Atenas. Por um lado, o ponto alto do império ático e a tentativa de legitimar, no plano do mito, o exclusivismo ateniense no acesso às grandes benesses da Simaquia de Delos, através de uma limitação do acesso à cidadania; por outro, os desmandos da 
democracia radical, aliada aos efeitos da Guerra do Peloponeso, que arrastariam a cidade para o declínio político e militar e motivariam, por isso mesmo, um saudosismo crescente, traduzido na evocação de uma putativa 'constituição ancestral', de contornos fluidos, mas reclamada pelos diferentes quadrantes políticos.

4. "Pólis, teatro e exercício da cidadania": no sistema da pólis, o envolvimento do cidadão individual em tarefas com impacto coletivo alargava-se a todos os domínios de atuação, em matéria religiosa, política, militar, financeira ou mesmo recreativa. A este nível, tem particular destaque o fenómeno teatral, enquanto força viva que espelha intensamente a forma como as esferas do polites e do idiotes se cruzam e interpelam, acompanhando assim de perto as tensões e desafios a que a pólis vai sendo sujeita, ao confrontar os seus membros, no plano metafórico do passado heróico da tragédia ou na utopia indagadora da comédia, com os grandes problemas do momento. É a esse fenómeno que se dedica este capítulo, através de uma abordagem de alguns dos aspetos que contribuem para acentuar a dimensão 'política' do teatro, seja no plano material dos bastidores do espetáculo, seja ainda através da análise concreta do fundo legal visível no desenvolvimento da estrutura do Íon de Eurípides.

5. "Polites, idiotes, kosmopolites: a Atenas de Fócion": as fontes mostram, com alguma frequência, que a noção de polites e a de idiotes (enquanto 'cidadão privado') podem conviver de forma relativamente pacífica e até ser mesmo tomadas como quase sinónimas, na altura de designar o cidadão comum, enquanto 'átomo' central do corpo cívico, cuja agregação num grupo mais vasto dá origem à coletividade (to koinon, to demosion) ou simplesmente pólis. Por conseguinte, o conceito de idiotes convive bem com o de polites, enquanto a preocupação com o conforto privado não se sobrepuser aos imperativos da comunidade. É precisamente esse equilíbrio que se vai perder, ao longo do séc. Iv, em Atenas, constituindo um sintoma denunciador da própria perda progressiva de liberdade em relação à Macedónia. A existência de Fócion, um dos últimos grandes estadistas desse período, serve de guia a esta análise, pois espelha de maneira particularmente visível as tensões que marcavam esse ponto de viragem na história do mundo antigo.

6. "Alexandre Magno: da estratégia pan-helénica ao cosmopolitismo": neste processo lato de transformação política e social, o soberano da Macedónia ocupa um posto central. Com efeito, da experiência pan-helénica, que o levou, 
como hegemon da Hélade, até onde os Gregos nunca tinham antes chegado, Alexandre foi evoluindo para uma nova ideologia de fusão étnica e cultural, onde a homonoia e a koinonia eram o novo elo de ligação. Ao estimular a concretização destes princípios, Alexandre lançava também as bases do cosmopolitismo e a experiência de globalização que haveriam de caracterizar a época helenística durante séculos.

7. "Alexandria: identidade e cosmopolitismo": uma das marcas distintivas da época helenística e também da visão empreendedora de Alexandre diz respeito ao surgimento de novas cidades, que poderiam atingir centenas de milhares de habitantes - uma concentração demográfica que seria impensável nas póleis clássicas. A mais emblemática dessas urbes cosmopolitas é seguramente Alexandria, que viria a substituir Mênfis como capital do reino do Egipto, sob o poder dos Ptolomeus, e onde pontificavam construções emblemáticas como a Biblioteca, o Museu e o Farol. Apesar deste processo de fusão étnica, cultural e linguística que está na base do enorme desenvolvimento alcançado pela cidade, era ainda assim possível a determinado grupo manter uma identidade própria (a nível cultural, religioso e político) num espaço profundamente marcado pelo cosmopolitismo e pela confluência de sensibilidades. As comunidades macedónia e grega, que estavam mais próximas da elite governativa, conseguiram encontrar uma fórmula hábil para se orientar por normas que remetiam para uma identidade política e cultural comum, traduzida no conceito de politikoi nomoi. A comunidade judaica, que era igualmente importante na cidade, teria, segundo a tradição literária, conseguido alcançar também assinaláveis benefícios de Alexandre e dos Ptolomeus, em especial o direito de 'viver de acordo com as suas leis ancestrais'. Neste processo de afirmação identitária, terá detido um papel determinante a tradução da Torá pelos Septuaginta, ao permitir que este texto sagrado ganhasse um posto comparável aos nomoi gregos, ou seja, contribuindo para o estabelecimento de uma koine legal, que, sem poder sobrepor-se à autoridade real, deteria ainda assim uma enorme importância na vida quotidiana e na gestão de conflitos entre privados.

8. "Paulo de Tarso e a justiça dos homens: helenismo e impiedade religiosa nos Atos dos Apóstolos": o empenho e espírito de entrega das primeiras comunidades cristãs bem como o acompanhamento das deambulações missionárias dos anunciadores da boa nova de Jesus Cristo fazem com que o livro dos Atos 
dos Apóstolos represente, além de um importantíssimo escrito doutrinário e um notável testemunho de fé, também um revelador documento de época. Por outro lado, as viagens de Paulo, que o levam desde Jerusalém até Roma, depois de percorrer regiões asiáticas e gregas, criam condições para identificar, no seu discurso e atuação, a confluência de múltiplas sensibilidades, em relação às quais o cristianismo nascente vem trazer perturbadoras novidades. E se isso justifica plenamente que Paulo, proveniente de Tarso, possa ser considerado (enquanto grego, romano, judeu e cristão) um verdadeiro kosmopolites do ponto de vista da experiência religiosa, política e legal, também ajuda a entender parte das estratégias de argumentação que, muito habilmente, ele soube produzir e adaptar, segundo o auditório formal ou de ocasião que escutava as suas palavras.

Salvo expressa indicação em contrário, todas as datas referidas ao longo dos capítulos deste volume remetem para um período anterior à era cristã. As traduções apresentadas são sempre da responsabilidade do autor do livro, com exceção de alguns casos em que se indica expressamente, em nota, o nome de outro tradutor.

Ao elaborar esta análise da experiência da globalização no mundo antigo, procurou-se respeitar um princípio que nunca é fácil de atingir em plenitude: encontrar o equilíbrio entre uma forma de exposição que possa ser simultaneamente útil a especialistas em antiguidade clássica, a estudantes de nível avançado e ainda ao público em geral. Se esse desígnio foi atingido, apenas o tempo e os leitores o poderão confirmar. Da parte do autor resta formular o propósito de que a leitura desta obra possa ao menos estimular, ainda que em escala mais reduzida, o grau da satisfação que o processo de escrita motivou.

Coimbra, fevereiro de 2012

Delfim F. Leão 
(Página deixada propositadamente em branco) 


\section{ENQUADRAMENTO GERAL DO POLITES AO KOSMOPOLITES}

\subsection{Pólis: a formação do polites para o exercício da cidadania}

Quando Simónides, o grande cantor da resistência grega às invasões persas, afirmava que "a pólis é mestra do homem"2 (frg. 15 West), estava também a sintetizar, com a sua reconhecida habilidade para construir frases lapidares, o essencial da existência da Hélade ao longo das épocas arcaica e clássica. Neste período, a Grécia desenvolveu e apurou o sistema da pólis, como a forma ideal de se organizar em sociedade, uma opção que, na ótica helénica, era muito preferível à autocracia bárbara, a qual apenas reconhecia a liberdade total do monarca - tanto mais absoluta e caprichosa quanto menor fosse o espaço de atuação dos respetivos súbditos. À dependência destes, o espírito grego contrapunha a soberania da lei, que ora vinculava o cidadão anónimo e indigente, ora o magistrado mais zeloso das suas funções. É certo que nem todas as póleis tiveram capacidade (ou ensejo) de cumprir, de forma igualmente isenta e eficaz, este ideal de orgulhosa autonomia, embora ele fosse partilhado, em termos gerais, por todas as cidades-estado. Não surpreende, por isso, que este princípio surja, a cada passo, nas obras literárias e constitua, em particular, a fonte perene que alimenta o caudal de grandes emoções retratadas no teatro, especialmente na tragédia, como adiante se verá (infra 4.3).

\footnotetext{
1 As ideias apresentadas ao longo deste enquadramento correspondem, no essencial, à argumentação desenvolvida em Leão (2009).

2 Salvo expressa indicação em contrário, todas as traduções apresentadas ao longo deste livro são feitas, pelo autor, diretamente a partir do original.
} 
A educação pela pólis e para a pólis (isto é, para o exercício empenhado e consciente da cidadania) exige de cada polites um envolvimento direto nos interesses da cidade, tarefa que representava, ao mesmo tempo, uma prerrogativa e uma obrigação. Antes de mais, um privilégio, em relação a todos quantos se encontravam excluídos, em maior ou menor grau, do uso pleno daquele estatuto (estrangeiros, metecos, escravos, mulheres e crianças), quer uma tal situação fosse definitiva ou apenas temporária (como aconteceria com uma criança filha de pais cidadãos, que não houvesse atingido ainda a maioridade). Mas o exercício da cidadania constituía também uma obrigação, à qual alguns poderiam sentir a tentação de fugir. ${ }^{3}$ Ao cidadão comum, mesmo que não fosse particularmente ambicioso, o estado exigia, em particular, o envolvimento nas atividades militares, na administração da pólis e na aplicação da justiça. Estes domínios constituíam, de início, um rigoroso exclusivo da aristocracia dominante, pois estavam intimamente ligados à nobreza de nascimento e à riqueza individual disponível. Por tal motivo, o alargamento da base de acesso a estas prerrogativas resultaria apenas de um longo processo de lutas intensas, relacionadas com fatores como a colonização, o desenvolvimento do comércio e da indústria, a introdução da moeda e o acelerado surgimento de plutocratas, a alteração das táticas de combate (como o predomínio da infantaria ligeira), que tornavam menos dispendiosa e mais acessível a participação em campanhas militares. Para responder à pressão destes poderosos fatores de mudança, a Grécia irá assistir ao movimento generalizado dos legisladores (cujos códigos de normas escritas visavam tornar mais clara e imparcial a aplicação da lei), bem como ao estabelecimento de numerosas tiranias, cujo colapso, após duas ou três gerações de governo, conduzira, em geral, à implantação de oligarquias ou de regimes democráticos mais ou menos evoluídos.

Característico, porém, do sistema da pólis era o seu particularismo e a forte determinação de manter uma autonomia e identidade próprias. E assim, da mesma forma que a Hélade representava para os Gregos um espaço cultural e ideológico comum, que lhes permitia cultivar, em relação aos que não partilhavam esse mesmo universo de valores, uma orgulhosa consciência de superioridade

\footnotetext{
3 Para evitar, por exemplo, colocar a vida em risco no campo de batalha ou dispor dos próprios bens para levar a cabo um oneroso serviço público, no caso de se ser escolhido para cumprir uma liturgia (infra 4.2).
} 
moral, sofria igualmente de uma incapacidade congénita para se agregar numa grande nação. Para isso acontecer, cada cidade teria de abdicar da pretensão de ser um estado autónomo e soberano (com leis e constituição próprias), capaz de promover uma política interna e externa independente - e perder estas características equivalia a negar a própria essência do sistema. Por conseguinte, à parte alianças pontuais com outras póleis, motivadas por necessidades com frequência igualmente pontuais, as cidades-estado preferiam cultivar por norma a autarcia e um regime de participação direta no governo, o que obrigava, em ambos os casos, a manter o estado e o corpo de cidadãos dentro de limites relativamente reduzidos.

\subsubsection{As Guerras Medo-persas e o imperialismo ático}

A Grécia não deixou, ainda assim, de experimentar as vantagens da união helénica, motivada porém não pelo desejo natural de agregação, mas pela urgência premente de resistir a um adversário comum: o tradicional inimigo persa. A oposição grega, liderada em Maratona (490) e Salamina (480) por Atenas, granjeou um sucesso tão estrondoso quanto surpreendente, como ilustra o facto de até o oráculo de Apolo em Delfos ter 'medizado' (como então se dizia), ao prever a vitória medo-persa. ${ }^{4}$ Para as cidades gregas aliadas, este sucesso abria uma oportunidade única de se afirmarem enquanto modelos de organização política e militar. De facto, entre a retirada persa e o início da Guerra do Peloponeso (431) estende-se um período de quase meio século, ao qual, por isso mesmo, se atribui usualmente o nome de Pentekontaetia. ${ }^{5}$ Valerá a pena recordar alguns dos aspetos que fazem com que esta época seja tão especial, sobretudo no caso

4 Certamente procurando acautelar a própria sorte, ao preparar um alinhamento com o previsível vencedor do conflito. No entanto e apesar deste 'engano', o oráculo manteve no futuro a sua credibilidade e influência, pois os Gregos, que não tinham propriamente uma casta sacerdotal e um livro sagrado que lhes servissem de guia espiritual, necessitavam de acreditar na clarividência de Apolo para sondar os desígnios divinos.

5 O criador do conceito é Tucídides; num excurso famoso (1.89-118), o historiador analisa o crescente imperialismo ateniense, que constitui, segundo ele, o verdadeiro motivo que levou à eclosão daquele conflito entre Helenos, de consequências desastrosas para todo o mundo grego. Em Leão (2001), 43-72, explorou-se, com mais pormenor, a matéria agora abordada. 
da Ática, pois ilustram de forma paradigmática o sucesso do sistema da pólis na sua realização mais perfeita: o regime democrático.

Em 477, ainda no rescaldo das Guerras Medo-persas, era criada a Simaquia de Delos de forma a defender os interesses gregos e a manter as forças persas à distância. Essa confederação vai permitir à cidade de Atenas estabelecer um verdadeiro império tributário, baseado no poder a na eficácia da frota, e alargar a influência política, favorecendo a instauração de democracias nas póleis aliadas. Estas contribuíam para o esforço conjunto de prevenção ora com navios ora com dinheiro. As cotizações monetárias passavam a integrar um tesouro comum, que ficara depositado, inicialmente, na sede da Simaquia, em Delos, sendo mais tarde (em 454) transferido para Atenas e usado para reconstruir os templos, sobretudo os da Acrópole, que tinham ficado à mercê do saque persa. Esta decisão, vista como abusiva pelos aliados, vai ainda assim criar condições para levar a cabo obras monumentais, que, além de constituírem uma importante fonte de emprego, são igualmente a face visível da grandeza de Atenas. No domínio político, as reformas de Clístenes eram aperfeiçoadas por Efialtes e Péricles, de forma que, em meados do séc. v, o equilíbrio e harmonia entre as diversas instituições permitiram atenuar grandemente o conflito de classes, concedendo possibilidades idênticas a todos os cidadãos. Era, portanto, a conjugação destes fatores que elevava Atenas a um pedestal de quase perfeição, permitindo a Péricles, o grande guia dos destinos da cidade, considerá-la a verdadeira "Escola da Hélade". ${ }^{\circ}$

\subsubsection{A Guerra do Peloponeso e os golpes contra a democracia}

Esta imagem de equilíbrio vai, contudo, ser profundamente abalada pela Guerra do Peloponeso (431-404). Entre as primeiras vítimas a cair encontra-se Péricles, que perece em 429, quando haviam decorrido cerca de dois anos e meio de conflito, vítima indireta da peste que entretanto grassara em Atenas. É convicção de Tucídides e dos estudiosos em geral que a Guerra do Peloponeso teria conhecido um desfecho diferente, se Péricles tivesse continuado à frente

\footnotetext{
6 Tucídides, 2.41.1.
} 
dos destinos da cidade que conduzira de forma única, já que nenhum dos seus sucessores lograra combinar de maneira tão notável as elevadas qualidades éticas e intelectuais necessárias a um estadista democrático.

Se, até ao início da Guerra do Peloponeso, o equilíbrio e sucesso da democracia ateniense haviam feito com que as fissuras no tecido social fossem reduzidas ao mínimo, a derrapagem económica e insucessos militares como a expedição à Sicília de 415, promovida pelo inconstante Alcibíades, vieram pôr em causa a eficácia da constituição democrática e reacender a contestação e as lutas políticas. Além de haver criado uma nova frente de batalha a ocidente, a clamorosa derrota de 413 acarretara pesadas baixas no potencial bélico ateniense e levara a armada a perder a tradição de invencibilidade. O momento era, portanto, favorável quer à revolta dos aliados desejosos de se libertarem do imperialismo ático, quer a um ataque em massa dos inimigos. Ainda assim, Atenas surpreendeu o mundo grego com a sua capacidade de regeneração, mas essas diligências apenas lograram adiar por algum tempo o golpe oligárquico de 411, cujos promotores viram nos desaires recentes uma oportunidade para reagirem contra a democracia.

Neste último quartel do séc. v, é possível reconhecer globalmente em Atenas três grupos políticos. ${ }^{7}$ As três orientações políticas em questão correspondiam aos democratas radicais, aos oligarcas extremistas e aos moderados. Os radicais defendiam o direito ao voto para todos os cidadãos, bem como a sua participação no governo, princípios tornados possíveis através de mecanismos como a tiragem à sorte e o pagamento do serviço cívico. Em termos de política externa, eram favoráveis à manutenção do imperialismo ático e à guerra contra os Peloponésios. Os extremistas, de acordo com os ideais oligárquicos, defendiam que apenas as classes mais elevadas pudessem ter acesso à cidadania e aos cargos políticos, sendo, por consequência, contrários à remuneração do serviço público. Para atingir estes objetivos mais rapidamente, os extremistas estavam dispostos a negociar a paz em termos menos vantajosos, de forma a garantirem o apoio de

7 Se bem que a identificação exata das diferenças existentes entre eles seja fonte de controvérsia para os estudiosos do problema, dificuldade essa reforçada pela relativa ligeireza com que algumas figuras mudavam de campo ou pela forma como surgiam divisões dentro de um grupo inicialmente unido. Esta contingência explica-se, em parte, pelo oportunismo de determinados políticos e pela importância que, nestes grupos, detinha a figura do líder, cuja mudança de ideologia poderia acarretar igual atitude nos 'seguidores'. 
Esparta. Já a posição dos moderados é mais difícil de esclarecer, pois ora aparecem ligados aos golpes oligárquicos de 411 e de 404 ora acabam por distanciar-se deles. Caso paradigmático encontra-se em Terâmenes, o principal líder dos moderados.

O testemunho de Tucídides (8.68.4) indica que ele deve ser incluído entre o número dos conspiradores que prepararam o golpe oligárquico de 411, embora não haja referência direta à sua participação nas atividades que precederam o derrube da democracia. ${ }^{8}$ Contudo o pai, Hágnon, era um democrata próximo de Péricles. Não existem, nas fontes, indícios claros das razões que terão levado Terâmenes a afastar-se da tradição democrática da família, para apoiar o golpe oligárquico. Não é, contudo, de pôr de lado a hipótese de influência dos sofistas (ele fora discípulo de Pródico de Ceos), ou a desilusão com o governo democrático, procurando nos oligarcas de 411 a liderança forte que buscará, depois da queda destes, em Alcibíades. ${ }^{9}$ De facto, Terâmenes continuou ativo depois da primeira restauração democrática de 410 e foi o grande negociador da paz com os Peloponésios, em 404. Começou, igualmente, por colaborar com o governo dos Trinta, acabando por vir a ser uma das suas vítimas. ${ }^{10}$

Deixando, contudo, de lado a controversa reconstituição dos eventos de 411, certo é que da propaganda decisiva a favor do golpe oligárquico fazia parte a crença em que a guerra contra Esparta não poderia saldar-se pela vitória a não ser com o apoio persa, cujas condições preliminares passavam pela substituição da democracia por um governo oligárquico. ${ }^{11}$ A resistência democrática à revolução oligárquica de 411 vai ficar centralizada nos marinheiros da frota ateniense estacionada em Samos. De facto, para que a conspiração fosse bem sucedida era necessário que a armada aceitasse a mudança. No entanto, os planos não

8 [Aristóteles] (Ath. 32.2) junta à ação determinante de Terâmenes também a de Pisandro e a do orador Antifonte. Tucídides (8.68.1-2), com indisfarçado respeito, considera este último o verdadeiro responsável pela arquitetura do golpe.

9 Cf. Diodoro 13.38.2. Contudo, Tucídides (8.97.3) não o liga expressamente a esta última diligência.

10 No discurso de acusação, Crítias insinua que Terâmenes, já desde o seu envolvimento com os Quatrocentos, era dado à traição dos antigos colegas sempre que alguma coisa começava a correr mal. Cf. Xenofonte, Hell. 2.3.30-34. Esta característica valeu-lhe a alcunha de kothornos (o 'coturno', tipo de calçado que poderia ser usado ora num pé ou no outro), pela forma como se adaptava às circunstâncias, mas Terâmenes aproveitou o remoque para ilustrar a sua diplomacia de carácter (id. ib. 2.3.47).

11 Alcibíades, por essa altura estacionado junto do sátrapa Tissafernes, recuperava terreno na vida política como possível mediador, embora as suas diligências no sentido de os Persas retirarem o apoio a Esparta para o darem a Atenas se tenham revelado infrutíferas. 
decorreram conforme haviam sido arquitetados. Falhou a tentativa de estabelecer uma oligarquia em Samos, que, garantindo o controlo da armada, fortalecesse o golpe em Atenas. Depois que Quéreas, enviado a Atenas para trazer notícias da situação, regressara e descrevera a ação dos oligarcas em termos ainda mais negros do que a realidade autorizaria, os marinheiros atenienses e os habitantes de Samos, ainda sob o efeito do relato, juraram defender a democracia até às últimas consequências. Convocaram uma assembleia, onde destituíram os trierarcas e estrategos em exercício, substituindo-os por outros, entre os quais se encontravam Trasibulo e Trasilo. Estavam definidos os dois grandes campos de ação e de influência políticas: os marinheiros, estacionados em Samos, e os golpistas, em Atenas. A breve trecho, porém, más campanhas militares deitariam por terra a já de si abalada credibilidade dos Quatrocentos, cuja aventura revolucionária terminaria alguns meses depois, com a restauração democrática, talvez no verão de 410 .

A Guerra do Peloponeso continuou o seu curso de destruição, com sucessos e desaires para ambas as partes. Em 406, os Atenienses conseguiriam uma importante vitória nas Arginusas, que poderia ter posto fim ao conflito, em termos relativamente vantajosos, mas os vencedores, liderados por Cleofonte, não aceitaram as condições de paz e Esparta voltou à ofensiva. E assim no ano seguinte, em Egospótamos, Atenas viria a sofrer a derrota definitiva, abrindo-se o caminho para a discussão dos termos da paz com o vencedor. No processo de negociação da paz, Terâmenes voltou a desempenhar um papel importante, primeiro junto de Lisandro, em Esparta, e, mais tarde, na defesa do acordo conseguido, já em Atenas.

$\mathrm{Na}$ seguimento das condições humilhantes impostas por Esparta (infra 3.3), o regime democrático foi novamente acometido por uma séria crise, favorecendo a instauração do governo dos Trinta Tiranos. ${ }^{12}$ Os oligarcas tentaram a aproximação a Trasibulo (que em 411 já estivera com os marinheiros de Samos, na oposição ao golpe oligárquico), convidando-o a preencher o lugar deixado vago pela

\footnotetext{
12 Marcado por uma violência extrema e inusitada para os padrões atenienses, associando, desde então, ao termo tirano uma conotação fortemente pejorativa.
} 
execução de Terâmenes. ${ }^{13} \mathrm{O}$ chefe da resistência negou-se a qualquer acordo com os Tiranos e a desistir da luta, a menos que fosse recuperado o estado de governo anterior à tirania dos Trinta, ou seja a democracia radical. Avançava-se, portanto, para uma situação de guerra civil, que viria a ser ultrapassada com a intervenção de Esparta, conduzida pelo rei Pausânias. Proclamou-se uma amnistia geral, que apenas não abrangia os Trinta Tiranos, os Dez que governaram o Pireu e os Onze, que constituíram o corpo de carrascos dos Trinta. E assim acontecia, em 403, a segunda restauração democrática. Apesar de muito abalada nas suas instituições, Atenas continuava a dar preferência ao regime da soberania popular.

\subsubsection{Séc. Iv: as crises de liderança e o declínio da pólis}

Na sequência do desfecho da Guerra do Peloponeso, a passagem para o séc. IV é acompanhada por um período de predominância de Esparta. No entanto, logo a partir de 394, aproveitando a oportunidade fornecida pela Guerra de Corinto, Atenas procura recuperar alguma da influência perdida e alia-se a outras cidades contra a prepotência em que degenerara a hegemonia espartana. Estes esforços levariam à criação, em 378/7, da Segunda Confederação. Motivados talvez pela preocupação de evitar o ressurgimento do imperialismo ático, que levara à Guerra do Peloponeso, certo é que alguns dos aliados começaram a exprimir a vontade de se libertarem da influência ateniense, sobretudo depois de Esparta ter sido derrotada, na batalha de Leuctras, em 371. Com a revolta de várias das cidades principais da Confederação, em 357, tem início a chamada Guerra Social, terminada em 355 com a intervenção persa. Para Atenas, isso significou o fim da tentativa de restauração imperialista, bem como de um modelo de diplomacia externa e de relacionamento entre cidades-estado que marcara grande parte do mundo grego no tempo de Péricles. Por outro lado, esta incapacidade — tanto de Atenas como de Esparta - para se manterem como centros de bipolarização política irá permitir a ascensão de outras póleis (como Corinto e Tebas) e em

13 De facto, Terâmenes tivera ainda um papel muito ativo em todos os acontecimentos que conduziram à assembleia que instaurou os Trinta, e é também possível que haja colaborado com estes últimos na fase inicial, mais moderada, do seu governo. Porém, com o tempo viria a distanciar-se dos Tiranos e esse antagonismo acabaria por levá-lo à morte, transformando-o numa espécie de mártir da causa moderada. 
particular a supremacia da Macedónia que, de região marginal da Hélade, considerada por muitos Gregos como antecâmara da própria barbárie, irá transformar-se no grande centro de comando. A hegemonia macedónica deve-se, em primeiro

lugar, a Filipe II, que, numa série de hábeis intervenções nos assuntos internos das cidades gregas, acaba por ser admitido no Conselho Anfictiónico (346) - o que, do ponto de vista diplomático, equivalia a reconhecer-lhe formalmente uma importante capacidade de influência no mundo helénico - e a fundar a Liga de Corinto (338), na sequência da vitória de Queroneia (que correspondeu, na prática, à conquista da Grécia pela Macedónia).

Filipe é assassinado pouco depois (336), numa altura em que preparava a invasão da Pérsia, aparecendo como chefe natural (hegemon) à frente de uma coligação pan-helénica liderada pela Macedónia. A morte violenta de Filipe não vai impedir a realização desta campanha, que será levada a cabo pelo filho e da qual advirão consequências determinantes para todo o mundo antigo (infra 6.3). O império de Alexandre Magno significará não apenas o fim da pólis (no que respeita à dinâmica descrita nas páginas anteriores), como também a criação de uma nova ordem, onde a tradicional oposição entre Gregos e bárbaros perderá terreno face a um processo de fusão étnica e cultural, e onde o particularismo da pólis, que exigia o envolvimento direto de cada polites na condução coletiva dos assuntos do estado (ta politika), será substituído pela crescente supremacia dos interesses privados ( $t a$ idia), em consequência da diluição das responsabilidades pessoais na realidade emergente dos reinos helenísticos. ${ }^{14}$

\subsection{Os reinos helenísticos: do polites ao kosmopolites}

\subsubsection{O legado macedónio}

Entre 336 (ano da morte do pai, Filipe II) e 323 (altura em que sucumbe à doença, por razões ainda hoje abertas a alguma especulação), Alexandre irá conquistar um império imenso, que ia desde a Europa até à Ásia profunda, englobando também o nordeste africano e boa parte da bacia do Mediterrâneo.

\footnotetext{
14 Para uma análise da evolução da agenda política de Alexandre e da forma como conduziu as suas campanhas, vide infra 6.3 e 6.4 .
} 
Tendo vivido pouco mais de trinta anos, é provável que o macedónio deixasse por cumprir alguns projetos que traria no pensamento, entre os quais se inclui a hipótese de expandir as conquistas para ocidente, se bem que não se possa afirmar com segurança que ele procurasse criar um império universal. Estas e outras questões permanecem em aberto, pois embora Alexandre estivesse rodeado de cronistas e historiadores oficiais que poderiam ter feito um registo bastante fiel das suas façanhas e intenções, a preocupação de agradar ao monarca bem como o processo de amplificação e de quase adoração a que foi sujeita a imagem do soberano acabaram por enublar múltiplos aspetos da sua atuação. Ainda assim, alguns factos são indiscutíveis, como a sua genial capacidade militar, a invulgar sagacidade política e ainda a liderança forte e carismática. Embora excecionais, estas qualidades não o teriam furtado a enfrentar duras provas para manter sob controlo o enorme império conquistado, como ilustram contrariedades e levantamentos com que teve de lidar dentro do próprio exército.

Em todo o caso, Alexandre marca o final de um período e lança, claramente, as fundações para a época helenística, uma era profundamente rica do ponto de vista económico, científico e cultural, que desaparecerá à medida que for avançando a fusão com a nova potência que se irá agigantando a ocidente: Roma. Politicamente, esses três séculos, que se prolongam até ao principado de Augusto, foram um período menos sujeito a instabilidades e alterações do que haviam sido as épocas arcaica e clássica. Parte da explicação encontra-se no facto de se estar perante reinos que englobam territórios extensos e populações numerosas e que, por conseguinte, se expõem, no conjunto, ao efeito perturbador de escaramuças de fronteira. No entanto, a principal razão prende-se com a centralização do poder político (e não raras vezes também económico) na figura do monarca, de quem dependia igualmente a máquina administrativa, que constituía, aliás, um dos aspetos notáveis deste período, fruto da combinação da experiência monárquica macedónia, com a longa tradição asiática e egípcia. Aliás, se do ponto de vista cultural e linguístico, a época helenística é dominada pela matriz grega (claramente preferida pelas elites dirigentes), ainda assim não se entende sem o influxo das outras culturas e etnias que entraram em contacto com o elemento grego e com ele se puderam fundir, criando a cultura transversal (koine) que se estenderá por toda a 'terra habitada' (oikoumene). 


\subsubsection{Os Diádocos e a criação das monarquias helenísticas}

Em todo o caso, pese embora o contributo determinante de Filipe e Alexandre, a cristalização dos traços essenciais da sociedade helenística deve muito igualmente à ação dos Diádocos, os generais que haviam estado ao serviço do jovem macedónio. De facto, com a morte de Alexandre e não estando resolvido o problema da sucessão, soltaram-se as forças centrífugas que o imperador lograra manter sob controlo. E embora, num primeiro momento, os Diádocos se tivessem comprometido a dividir a administração das províncias (mantendo-se no fundo como sátrapas, sem tentarem evoluir para monarcas independentes), enquanto aguardavam que o filho de Alexandre e Roxana (também Alexandre e que nascera após a morte do pai) atingisse a maioridade, o certo é que rapidamente se envolveram em pesadas lutas que se prolongariam, com intensidade variada, ao longo dos cinquenta anos subsequentes. Do inevitável desmembramento do império, sairia o embrião das futuras realezas helenísticas, até porque se revelaria ilusória a pretensão de vir a ocupar o posto de governante único nas mesmas condições que Alexandre. E assim surgiram os grandes reinos do Egipto, Macedónia, Ásia e, mais tarde, de Pérgamo, que, do ponto de vista político, se traduziram em monarquias hereditárias. Embora a posição do rei conhecesse variações quanto à forma de exercer a soberania, o certo é que este regime político se havia tornado numa necessidade histórica, pois só um poder central forte e estável poderia manter a coesão de territórios muito amplos, com acentuadas diferenças étnicas, culturais e geográficas. Uma vez que era o rei quem dava corpo ao estado, os seus poderes seriam, em princípio, ilimitados, no sentido de que formalmente o soberano não era obrigado a prestar contas a outra instância, se bem que, na prática, os monarcas helenísticos procurassem optar por soluções de governo que evitassem a conotação com um despotismo tirânico. Para dar a conhecer a sua vontade, serviam-se sobretudo de edictos reais, traduzidos em normas e decretos ou em instruções enviadas a magistrados ou cidades, consoante a natureza do assunto. Em qualquer dos casos, isso bastaria para se fazerem obedecer, a menos que o destinatário pretendesse desafiar a autoridade régia. Dado que o monarca se encarregava de receber pessoalmente embaixadores estrangeiros, magistrados e governadores provinciais, bem como representantes de póleis 'independentes', 
isso equivalia a dizer que dele dependia também toda a administração, bem como a condução da diplomacia externa. ${ }^{15}$

\subsubsection{A especialização dos serviços}

A citação de um verso do poeta Simónides, evocada no início deste estudo (supra 1.1), segundo a qual "a pólis é mestra do homem", assenta no princípio inerente de que a formação do indivíduo tem por fim último o exercício coletivo da cidadania. Por conseguinte, se todos os politai são chamados a participar na defesa, governo e administração da pólis, isso implica que tais atividades sejam vistas como expressão natural do estatuto de cidadão e não como uma tarefa de especialistas. Ora a situação na época helenística é exatamente a contrária, observando-se uma crescente profissionalização dos intervenientes nestes setores, facto que, por um lado, exprime a maior competência específica exigida para o cumprimento daquelas funções, mas também o progressivo e crescente alheamento do cidadão comum perante a noção de estado. A profissionalização é, portanto, sintoma de uma dinâmica social e económica distinta e nota-se, em especial, ao nível financeiro, militar e político.

Quanto ao aspeto financeiro, o surgimento de urbes muito populosas ${ }^{16}$ poderia obrigar a medidas de carácter social (como distribuição de bens de primeira necessidade), às quais seria necessário dar cabimento orçamental e que, além de funcionarem como formas de combate à pobreza, tinham também o objetivo político de prevenir distúrbios por parte da população carenciada e descontente. Além disso, a crescente mobilidade de pessoas e bens vinha dar maior complexidade às operações financeiras e obrigava também a desenvolver fortemente os sistemas de crédito, sobretudo para negócios que envolviam um risco acrescido (como o comércio marítimo), mas que poderiam igualmente

\footnotetext{
15 Como adiante se verá (infra 1.2.4), este aspeto, bem como o pagamento de tributo ao rei, constituía um dos sinais claros de que a autonomia das cidades-estado era apenas uma ficção conveniente, que servia tanto o amor-próprio das antigas póleis como a imagem de benemerência dos monarcas.

16 Grandes capitais como Alexandria poderiam atingir centenas de milhares de habitantes, uma concentração demográfica que seria impensável para as póleis clássicas. Sobre Alexandria, vide infra 7.1.2.
} 
gerar receitas bastante apreciáveis. Este conjunto de fatores levava a que os peritos financeiros ganhassem uma importância crescente na constituição do próprio governo. ${ }^{17}$ A especialização militar conduziu ao incremento da figura do mercenário ao serviço dos monarcas, a qual se apresentava não apenas como uma forma alternativa de sustento, quer para camponeses arruinados quer para a população acumulada nos centros urbanos, mas também como uma necessidade objetiva, enquanto forma de garantir o aperfeiçoamento de táticas militares (como a técnica de cerco às cidades). E uma vez que, por definição, o mercenário combate em troca de um soldo e não por um ideal de liberdade (conforme era regra no universo da pólis), dilui-se rapidamente o princípio do cidadão-soldado, bem como a ideia de pátria, porquanto poderia até acontecer que o mercenário se visse na contingência de lutar contra a terra-natal. Por último e na esteira dos aspetos anteriormente referidos, também a vida política passava de preferência para o domínio de profissionais (os oradores), pois a vitalidade própria do estatuto de cidadão interventivo perdia terreno perante o avanço da ideia de que o indivíduo é apenas súbdito de um rei e não o construtor da própria sorte.

Por conseguinte, a solução dos problemas individuais passava a ter primazia sobre a consciência de uma identidade coletiva, e porque o monarca controlava igualmente a vida administrativa e as grandes opções militares, mesmo estas áreas tradicionais de afirmação da pólis ficavam destituídas de real autonomia, embora continuassem a servir de rampa de lançamento para quem desejasse construir uma carreira nesses domínios. Ora uma vez que as elites governativas partilhavam uma cultura de base helénica, toda a máquina burocrática e económica dos reinos helenísticos funcionava como uma grande bolsa de emprego para as populações das antigas póleis gregas. Embora esta apetência pudesse esvaziar algumas cidades-estado dos seus elementos mais válidos, a procura de saberes especializados nas mais variadas áreas teve, ainda assim, a vantagem de promover a mobilidade de pessoas e de conhecimentos, bem como a fusão étnica, linguística e cultural (que dá corpo à noção de koine).

\footnotetext{
17 É certo que, mesmo na democracia radical, se evitava aplicar o mecanismo da tiragem à sorte no acesso a cargos onde era reconhecida a necessidade de uma aptidão específica (como acontecia precisamente com as áreas financeira e militar), mas o uso de medidas preventivas para evitar a incompetência não é o mesmo que promover a criação de carreiras especializadas.
} 


\subsubsection{Os limites de atuação das póleis helenísticas}

Ora uma vez que as antigas póleis continuaram a existir na época helenística, ao menos como espaços urbanos povoados, importa saber até que ponto mantinham alguma autonomia e liberdade efetiva de atuação. Uma vez que a essência do estado helenístico assentava na pessoa do monarca e no conjunto de magistrados que trabalhavam mais diretamente com ele, a estrutura da pólis constituía, em última análise, um corpo estranho dentro da nova realidade. Em todo o caso, não poderia ser simplesmente eliminado, dado o grande peso que tivera ao longo da história da Grécia. Desta forma, as póleis mantinham em funcionamento o aparato constitucional que possuíam no passado (assembleia popular, tribunais, magistrados eleitos anualmente); no entanto, estavam dependentes da vontade do rei, cujas ordens eram para ser cumpridas, ainda que fossem apenas transmitidas por carta, regulação (diagramma) ou ordenação (prostagma). Mantinha-se formalmente a aparência de autonomia, desde que houvesse a preocupação de moldar os decretos da pólis de acordo com as instruções do monarca, que eram assim transformadas em lei. ${ }^{18}$

Pode questionar-se até que ponto uma cidade teria capacidade para contrariar as instruções régias, sem com isso desafiar abertamente a autoridade central. $\mathrm{Na}$ verdade, as fontes deixam entrever que essa margem de manobra não existia, mesmo para cidades tão poderosas como Atenas. Plutarco fornece, a esse respeito, dois exemplos bastante expressivos. Em 318, Polisperconte, na qualidade de guardião do rei, enviou para Atenas Fócion e mais alguns fugitivos, a fim de lá serem julgados, se bem que, na realidade, o regente já houvesse dado instruções de que deveriam ser condenados à morte (Plutarco, Phoc. 34). É possível que Atenas chegasse por si mesma a idêntico veredicto, mas a hipótese de, no uso da sua pretensa liberdade e autonomia, vir a contrariar as instruções de Polisperconte só poderia ser efetivamente colocada se os Atenienses quisessem pôr em causa a autoridade do rei e sujeitar-se, em seguida, à provável retaliação. Portanto, ambas as partes observavam a formalidade fictícia de uma independência, mas, para evitar complicações futuras, o resultado não deveria desviar-se

\footnotetext{
18 Em todo o caso, o pagamento de tributos e a integração de guarnições reais, entre outros encargos suportados pela pólis, eram um símbolo inequívoco da sua dependência em relação ao poder do soberano.
} 
do esperado. ${ }^{19}$ Um outro exemplo ainda mais expressivo é dado pelo mesmo Plutarco, a propósito do rei macedónio Demétrio Poliorcetes. Incomodados com a sua ingerência em assuntos domésticos, Atenas aprovou um decreto que procurava limitar o raio de ação do monarca. No entanto, os Atenienses viram-se não só forçados a revogar o decreto em questão e a condenar à morte e exílio os respetivos proponentes, como ainda a aprovar um outro decreto, segundo o qual seria considerado sagrado perante os deuses e justo diante dos homens tudo o que Demétrio ordenasse (Demtr. 24.3-4). Em síntese: os Atenienses viram-se obrigados a integrar expressamente nas suas leis a autoridade real que tinham começado por pretender cercear. ${ }^{20}$

Do ponto de vista político, a maior debilidade da cidade-estado notava-se, em especial, na grande limitação (ou mesmo incapacidade real) para conduzir uma diplomacia externa independente. Para muitas das póleis de pequena dimensão, a articulação com a vontade do monarca equivalia, de alguma forma, à prática de alianças que efetuavam já no passado, por exemplo com a Simaquia de Delos ou a do Peloponeso. A mudança era sentida sobretudo por cidades importantes como Atenas ou Esparta, que estavam habituadas a funcionar como grandes estados autónomos, capazes de agregar e influenciar a política praticada por outros estados. É certo que os monarcas concediam às póleis (e por vezes até estimulavam) o direito de construir com outras cidades ligas ou simaquias (assentes na aliança voluntária de estados formalmente independentes), ou então criar confederações cujos órgãos centrais se baseavam na partilha de uma mesma cidadania (sympoliteia), ou ainda conceder em potência a cidadania plena (isopoliteia) aos politai de outra cidade, para o caso de estes optarem por abandonar a pólis de origem, fixando-se na que lhes concedera a isopoliteia. Por outro lado, mesmo na concessão da cidadania a particulares, as póleis continuavam a cultivar uma atitude defensiva e uma formalidade processual bastante complexa, que poderia fazer lembrar o mecanismo adotado na época clássica e suscitar, por conseguinte, a ideia de que a autonomia da cidade-estado se manteria quase intacta a esse nível. Há, no

\footnotetext{
19 A atuação de Fócion será adiante objeto de uma análise mais detida (infra 5.2).

20 Ainda assim, na sua atuação futura Demétrio teve o cuidado de não desprezar ostensivamente as leis atenienses, como mostra o episódio da iniciação nos Mistérios de Elêusis; uma vez que não podia estar em Atenas na altura devida, solicitou que se procurasse uma solução, ao que os Atenienses responderam alterando temporariamente o nome dos meses, para que a cerimónia pudesse decorrer com respeito pela formalidade (Demtr. 26).
} 
entanto, que registar uma diferença fundamental: mesmo admitindo que as póleis da época helenística até conservariam a mesma capacidade para conceder, em circunstâncias que considerassem excecionais, a cidadania a determinado particular ou coletividade que pretendiam honrar, não poderiam ainda assim transmitir aquilo que no passado era a essência deste processo — o estatuto de cidadão numa pólis verdadeiramente soberana e independente. Da antiga cidade-estado restava somente, na prática, a cidade enquanto centro urbano, com alguma autonomia a nível local e privilégios que poderiam ir além disso (como a isenção de impostos e o direito de asilo), mas que só ocasionalmente eram concedidos pelo monarca.

Aliás não deixa de ser sintomático que os sinais de empenho político e social fossem cada vez mais substituídos pela constituição de 'clubes' (koinon para os Gregos e collegium para os Romanos) de natureza privada e de adesão livre e voluntária, motivada pela simples afinidade de interesses lúdicos e culturais (tendo muitas vezes o ginásio como centro de reunião) ou então pela defesa de objetivos corporativos e profissionais (como era o caso das companhias de teatro e de atletas profissionais).

Os fenómenos até agora evocados, embora aparentemente dispersos, partilham o facto de ilustrarem a afirmação de um individualismo crescente, que tem por pano de fundo a crise do tradicional modelo cívico coletivo da pólis. O dilema, suscitado pelo movimento sofista no último quartel do séc. v, de saber se o homem deveria viver de acordo com as inclinações naturais (physis) ou antes segundo a norma (nomos) decorrente da existência em sociedade, fora resolvido por Aristóteles (Política, 1253a), ao sustentar que "por natureza (physis) o homem é um animal político (politikon zoon)": por outras palavras, a vida numa pólis, com as suas leis e convenções sociais, constitui o enquadramento natural e necessário para a natureza humana. A esta visão, as novas tendências filosóficas que acompanharam a passagem para a época helenística - em especial os Cínicos, com a sua intrínseca rebeldia contra todas as formas de disciplina e convenção social - vêm contrapor que physis e nomos poderão efetivamente identificar-se entre si, mas somente quando o homem puder seguir as inclinações naturais, entendendo o mundo inteiro como a sua cidade, ou seja, afirmando-se como um kosmopolites ou 'cidadão do mundo'. ${ }^{21}$

21 Diógenes Laércio (6.63), a propósito do cínico Diógenes. Se a afirmação for autêntica, permite atribuir ao desconcertante filósofo a criação do termo kosmopolites. 
Embora a leitura cínica levasse, em última instância, à anarquia generalizada (que não se chegou a verificar), os reinos helenísticos acabaram por recriar efetivamente o cenário de um mundo globalizado, onde os projetos individuais tinham mais peso do que a realização de um ideal comum. ${ }^{22}$ Do empenho num compromisso coletivo (ta politika), que remetia para segundo plano os anseios pessoais (ta idia), passou-se à procura da felicidade de cada um - não tanto porque a grandeza de pessoas singulares não se conseguisse acomodar nas calhas estreitas das obrigações sociais, mas antes porque a fraqueza da sociedade deixara de motivar o indivíduo particular (idiotes), libertando-o para o anonimato de um circuito de mobilidade mais vasto. Do polites se evoluía assim para o kosmopolites, do carácter local da cidade-estado para o mundo globalizado da oikoumene.

22 A evolução do teatro espelha de forma paradigmática esta transformação, evidente quando se compara, por exemplo, a natureza 'política' dos enredos da produção aristofânica ou da própria tragédia (infra 4.3.1) com o meio familiar e o triângulo amoroso que estão na base da comédia nova de Menandro. 
(Página deixada propositadamente em branco) 


\section{LICURGO O MÍTICO CRIADOR DA CONSTITUIÇÃO ESPARTANA}

\subsection{A ideia de Esparta}

No segundo livro da Ilíada de Homero, num passo famoso conhecido por "Catálogo das Naus", vem descrito o impressionante contingente de navios que se juntaram a Agamémnon na expedição contra Troia. A nível histórico, esta coligação de forças micénicas teve como provável motivação a tentativa de conquistar uma rica cidade, situada num ponto estratégico de rotas comerciais. Porém, quando se fala das causas da guerra de Troia, a primeira justificação que ocorre não é seguramente essa, mas uma outra, de natureza bastante diferente: as tropas que, sob o comando geral do rei de Micenas, aceitaram avançar contra a cidade de Príamo pretendiam, antes de mais, resgatar Helena, esposa de Menelau e portanto cunhada de Agamémnon, que teria sido raptada pelo príncipe Páris, numa altura em que este era hóspede de Menelau. Segundo Homero, a beleza de Helena foi portanto a causa direta da guerra que acabaria por ditar a destruição de Troia, ao fim de um sítio de longos anos. ${ }^{1}$ Esta explicação deriva, obviamente, da ficção literária criada na monumental obra homérica e não pode ser autenticada por uma fonte histórica independente, mas, na sua genial simplicidade, garantiu a primeira nota de imortalidade a Esparta. Com efeito,

\footnotetext{
1 Essa notável beleza justificava, inclusive, que os anciãos de Troia compreendessem as razões que levavam a que Troianos e Gregos lutassem havia tantos anos por uma mulher assim, embora preferissem que ela embarcasse nos navios de quem a reclamava, devolvendo a paz à cidade. Cf. Il. 3.146-160.
} 
ao descrever os navios que integravam a força grega invasora, Homero diz o seguinte sobre Menelau (Il. 2.581-590): ${ }^{2}$

Os que detinham a ravinosa Lacedemónia cheia de grutas,

Fáris e Esparta e Messa cheia de pombas,

que habitavam Briseias e as agradáveis Augeias,

senhores de Amiclas e de Helo, cidadela junto do mar;

eles que detinham Laas e habitavam Étilo:

deles comandava o irmão, Menelau excelente em auxílio,

sessenta naus, separadamente alinhadas.

Entre elas se movimentava confiante na própria vontade,

incitando-os à guerra; muito queria ele no coração

vingar os estrebuchamentos e lamentações de Helena.

Apesar de, na lógica do poema épico, Agamémnon deter uma importância superior à de Menelau (em especial do ponto de vista político e diplomático), ainda assim o marido injuriado acabaria por conhecer, a médio prazo, um sucesso superior ao do irmão. É certo que Agamémnon regressará a casa coberto de magnificência, como o grande vencedor de Troia, mas para encontrar pouco depois um fim indigno da sua condição de guerreiro, às mãos de Clitemnestra - essa 'mulher dotada de másculos desígnios e de um coração cheio de expetativa', como a ela se viria a referir Ésquilo, na tragédia Agamémnon, ${ }^{3}$ munida portanto de um espírito afoito e varonil num universo dominado pelos homens. Menelau, mesmo ocupando um lugar subalterno em relação ao irmão, seria mais bem sucedido, como se pode depreender do impacto que, já na Odisseia, teria sobre Telémaco a visita feita ao antigo companheiro de armas de Ulisses. À vista do palácio magnífico, que o jovem compara ao esplendor da própria corte de Zeus Olímpico (Od. 4.65-75), há a juntar a recuperação de Helena, que mantinha o porte e elegância de outrora (Od. 4.120-136), bem como a imagem de poder de Menelau, que destoa não apenas da morte inglória que colhera o irmão, como estabelece um notável contraste com a situação de Ítaca, onde Penélope

\footnotetext{
2 Tradução de Lourenço (2005).

3 Ag. 11.
} 
e Telémaco enfrentam grandes dificuldades em manter a ordem e afirmar a sua autoridade. Com efeito, Menelau, em reconhecimento pela amizade que o ligava a Ulisses, logo informa o visitante de que estaria na disposição de conceder ao antigo companheiro morada junto de si, nem que para isso fosse necessário despovoar uma das cidades que estavam sob o seu domínio (Od. 4.168-182).

O carácter excecional destas figuras da epopeia é bem visível no poderoso impacto que tiveram sobre a tradição literária posterior, em especial no universo da tragédia, dadas as enormes potencialidades dramáticas decorrentes de todos os eventos extremos ligados ao ciclo troiano. De facto, a saga da casa dos Atridas começava por ter implicações éticas, que eram herdeiras, antes de mais, dos antigos códigos que norteavam o comportamento dos heróis homéricos, tanto no que se refere à atuação em combate, como ainda, e sobretudo, aos laços de hospitalidade. A esse nível, a forma como Páris desrespeitou Menelau, seu anfitrião, ao raptar-lhe a esposa, foi uma transgressão óbvia e evidente das mais elementares regras de convívio humano, mas constituiu ainda um grave erro de diplomacia externa. De facto, a ofensa não era somente pessoal e familiar, mas revestia-se também de um significado político, que vinculava o oikos dos Atridas e a cidade de Troia. Ou seja, exprimia uma afronta direta de um estado a outro estado independente, feita na pessoa de um dos seus mais elevados representantes, circunstância que exigia uma reparação à altura do agravo cometido. Por outro lado, as consequências diretas do conflito, tanto para vencedores como para vencidos, não mais deixariam de constituir uma fonte de inspiração sobre as implicações da guerra. Entre essa galeria de personagens notáveis, destaca-se, pela própria ambivalência de juízos que inspira, a figura de Helena, afinal a primeira espartana marcante, exemplo de mulher bela e fatal, mas também de fêmea independente e caprichosa, contribuindo assim para desenhar um paradigma de beleza e de liberdade sexual que marcaria de igual forma as espartanas da época arcaica e clássica, ainda que a solenidade com que faz a sua aparição no mundo homérico implique uma realidade muito diferente da que marcará a educação feminina lacedemónia em época posterior. ${ }^{4}$

Ao evocar os nomes de Menelau e de Helena, a análise desloca-se para o final da época micénica e, portanto, para um período muito anterior à emergência e

4 Sobre a imagem de Helena, simultaneamente de Troia e de Esparta, vide Cartledge (2003) 46-57. 
afirmação de Esparta enquanto cidade-estado. Por outro lado, o tempo heróico em que estas personalidades terão vivido eleva-as a um nível quase mítico e assim menos tangível do ponto de vista histórico. De resto, idêntica leitura se poderá fazer relativamente a muitos aspetos ligados à realidade espartana, em épocas posteriores. Com efeito, à insuficiência da informação veiculada por fontes diretas - em grande parte explicada pela ausência de uma produção literária pujante (ao contrário do que aconteceu com a rival Atenas) — vem juntar-se a tendência para a exploração ideológica (positiva ou negativa) da imagem de Esparta entre autores de outras proveniências geográficas que trataram a questão da Lacedemónia. Em resultado deste cenário, a reconstituição da sociedade lacónica enfrenta mais dúvidas e dificuldades do que seria de prever, se for tida como ponto de referência a sua importância na história da Hélade.

Não obstante os feitos bélicos que Esparta desde cedo realizou (como a determinante conquista da Messénia, disputada num conflito com várias fases, mas cujo início remonta à segunda metade do séc. viII), a afirmação da sua imagem dentro do panorama global grego deve muito a um acontecimento bastante posterior: ao papel desempenhado nas Guerras Medo-persas, em especial em certos momentos de enorme tensão emocional coletiva, nas primeiras duas décadas do séc. v. Com efeito, não obstante o facto de as cidades da Grécia continental admirarem Atenas pela vitória alcançada em Maratona (em 490), continuavam a identificar a liderança de uma frente comum contra os Persas mais naturalmente com a Lacedemónia do que com a Ática. ${ }^{5}$ Durante o conflito, tanto os invasores persas como a resistência helénica procuraram atrair os restantes Gregos à sua causa e houve, de facto, muitas cidades que optaram por 'medizar', isto é, por alinhar com as forças inimigas. De resto, o próprio oráculo de Apolo em Delfos desencorajava claramente a resistência, tal o impacto causado pelo avanço imparável dos contingentes persas. ${ }^{6}$ Os Lacedemónios e os seus aliados (symmachoi) constituíam o núcleo da resistência helénica, ${ }^{7}$ embora a Aliança Grega — ou simplesmente os 'Gregos' (Hellenes, e.g. Heródoto, 7.173.1) — não coincidisse totalmente com esta estrutura, em especial em termos de orgânica governativa,

\footnotetext{
5 Sobre este momento crucial da história da Grécia, vide Ferreira \& Leão (2010), 147-170, esp. 164-168, cuja linha de argumentação é aqui parcialmente utilizada.

6 E.g. Heródoto, 7.140; 7.220.

7 Conforme Heródoto salienta, por duas vezes (7.157.1; 8.142.4).
} 
pois cada estado individual contava somente por um voto através dos respetivos 'delegados' (probouloi) ao Congresso Helénico. A decisão maioritária dos votantes seria vinculativa, mesmo para póleis como Esparta e Atenas. As forças terrestres provinham essencialmente do Peloponeso, enquanto as navais procediam em especial das cidades do Golfo Sarónico, mas em ambos os casos enfrentavam contingentes persas bastante superiores.

Enquanto Xerxes se encontrava na Macedónia, os Gregos discutiam no Congresso do Istmo a estratégia a adotar, tendo a maioria sido favorável a ocupar o estreito das Termópilas bem como a estacionar a armada em Artemísio. Estas posições ficavam suficientemente próximas uma da outra para permitirem o contacto entre o exército e a frota, articulando assim a respetiva atuação de acordo com a evolução dos acontecimentos. O rei espartano Leónidas comandava as forças nas Termópilas, enquanto a armada tinha por general supremo o também espartano Euribíades. ${ }^{8}$ A espera nas Termópilas foi improcedente do ponto de vista militar, pois os Gregos acabaram vencidos, tendo perdido cerca de quatro mil homens (dos quais metade seria talvez constituída por Hilotas). Do lado persa tombaram à volta de vinte mil combatentes e, embora isso não afetasse grandemente as suas forças, do ponto de vista moral a resistência helénica - e em especial a do rei Leónidas e dos seus trezentos Espartanos — ficaria como um futuro símbolo poderosíssimo da anulação das vontades individuais em favor de um objetivo comum e da entrega sem reservas ao dever de resistir ao invasor em defesa da independência e da liberdade? Isso mesmo atesta, com exemplar concisão, o epitáfio que mais tarde o poeta Simónides para eles compôs (Heródoto, 7.228.2):

Estrangeiro, vai anunciar aos Lacedemónios que aqui jazemos, por obedecermos às suas ordens (rhemata).

Este epitáfio concentra, com notável eficácia, as marcas de excelência do guerreiro espartano: a dedicação resoluta à causa da pólis, o total repúdio pela

\footnotetext{
8 Cf. Heródoto, 8.2. Entre os interlocutores privilegiados do comandante da armada encontrava-se o ateniense Temístocles, que havia sido eleito estratego e estava à frente do contingente mais numeroso de barcos.

9 Cálculo das baixas em Hammond (1986) 236-237. Sobre os pormenores e simbolismo que envolveram a batalha das Termópilas, vide Cartledge (2007).
} 
covardia, a obediência incondicional às 'ordens' ou 'leis' — palavras que podem ser usadas para traduzir o vocábulo rhemata, no original. O termo grego escolhido por Simónides não é indiferente, já que poderia ter adotado uma palavra mais usual, como nomoi, mas o efeito não seria o mesmo. Na verdade, a palavra rhema significa, antes de mais, 'o que é dito' ou 'o que é proferido', remetendo assim para um ditame de certa forma oracular que ganhou entretanto força de lei inamovível. Conforme adiante se verá (infra 2.2.), é este o sentido primeiro de rhetra, uma palavra com a mesma raiz etimológica de rhema, ${ }^{10}$ e que, aplicada ao contexto espartano, ganha um sentido especial, na medida em que a expressão "Grande Rhetra" se especializou para designar as leis instituídas por Licurgo. Na sua concisão emblemática e tão de acordo com a tradicional braquilogia espartana, o epitáfio sugere assim, de maneira evidente, que Leónidas (e por extensão os seus trezentos Espartanos) era elevado ao estatuto de paradigma ilustrativo da excelência guerreira produzida pela educação (ou agoge) decorrente da aplicação da rhetra estabelecida pelo antigo legislador. A batalha das Termópilas saldou-se, do ponto de vista militar, por uma derrota objetiva, já que os Espartanos acabaram todos mortos e os Persas prosseguiram a sua marcha, mas o enorme impacto que teve no moral das tropas gregas irá ser determinante para relançar a resistência helénica e alcançar as vitórias finais de Salamina e de Plateias.

Já quanto à batalha de Artemísio, o desfecho foi mais favorável aos Gregos, pois, com uma parte somente da sua frota, as forças aliadas conseguiram rebater a poderosa armada persa, havendo mesmo capturado trinta barcos e destruído muitos outros, não sem a preciosa conivência dos elementos naturais. Por este conjunto de razões, o seu ânimo era elevado, até porque acreditavam que tinham os deuses marinhos do seu lado. A distinção na batalha foi dada aos Atenienses, por haverem "lançado as brilhantes fundações da liberdade", nas palavras de Píndaro. ${ }^{11}$

A vitória grega em Artemísio ficou a dever-se, em boa parte, à atuação de Temístocles, mas a marca da sua liderança será visível, em especial, junto à ilha de Salamina, em cuja baía os Gregos haviam concentrado todas as suas forças,

\footnotetext{
10 Vide Liddell \& Scott (1996), s.v. rhema; rhetra.

11 Frg. 77 Snell, citado por Plutarco, Them. 8.2.
} 
numa posição bastante próxima da adotada em Artemísio, embora com superior vantagem estratégica. ${ }^{12}$ De novo, o comando supremo fora confiado a Espartanos: as tropas acampadas no Istmo eram chefiadas por Cleômbroto, irmão do rei Leónidas que havia perecido nas Termópilas; à frente da armada fora reconduzido Euribíades, em reconhecimento das ótimas qualidades demonstradas em Artemísio. ${ }^{13}$ Temístocles era um dos representantes atenienses no Congresso Helénico e terá pressionado para ser adotada a estratégia de estacionar a armada em Salamina, resolvendo assim a terrível situação terrestre na Ática, ao cobrir a retirada da população e ao depositar a esperança de vitória na frota. ${ }^{14}$ Depois da chegada de Xerxes a Atenas, a visão do fumo que se erguia da Acrópole despertou o pavor nos Gregos estacionados em Salamina, com a maioria a querer retirar para o Istmo. O próprio Euribíades estava inclinado para essa opção, mas Temístocles conseguiu convencê-lo das vantagens de permanecerem no local. Além de ter conseguido travar a debandada, a intervenção do general ateniense foi determinante ainda para dar ânimo às tripulações e para fazer chegar aos Persas a falsa indicação de que os Gregos estavam profundamente desmoralizados, levando Xerxes a aproveitar o momento para atacar. Em Salamina, a Aliança Grega alcançou uma grande vitória, graças à sua capacidade tática e ao notável esforço de combate dos marinheiros gregos. ${ }^{15}$

Ainda assim, o recontro de Salamina não representou o fim da guerra, pois os barcos persas ainda eram superiores em número, mas Xerxes decidiu recuar para não se expor ao inverno, deixando um grande contingente acampado na Tessália, sob o comando de Mardónio. Com efeito, naquele momento o perigo até seria maior, na medida em que estas forças eram constituídas por tropas de elite, sendo, por conseguinte, mais eficazes do que o enorme e lento exército que começara por acompanhar Xerxes. A primeira preocupação de Mardónio

\footnotetext{
12 Reconstituição dos pormenores da batalha em Hammond (1986) 237-244.

13 Heródoto, 8.42; 8.71.

14 Esta solução apoiava-se, de resto, na hábil utilização do oráculo proferido pela pitonisa em Delfos (Heródoto, 7.141), ao interpretar a "muralha de madeira" como indicação para concentrar a resistência na armada.

15 Curiosamente, o primeiro prémio de bravura foi dado aos Eginetas, pois foram quem se tinha exposto mais na linha de batalha, mas coube aos Atenienses o mérito de terem virado a sorte do combate a favor dos Gregos.
} 
consistiu em separar os Atenienses da causa grega, oferecendo um entendimento em termos vantajosos, mas que acabariam sendo recusados.

$\mathrm{Na}$ realidade, o risco de separação existia de facto. Depois de Salamina, os Atenienses escolheram como seus líderes Aristides e Xantipo (que haviam entretanto regressado do exílio, beneficiando da amnistia geral anterior à invasão persa) e não Temístocles. No entanto, Aristides confirmou de forma categórica a oposição à Pérsia, de maneira que a campanha iria continuar. A batalha decisiva seria então disputada em 479, junto de Plateias, tendo o exército grego combatido sob o comando de Pausânias, sobrinho de Leónidas e regente em lugar de Plistarco, filho do herói das Termópilas. O ataque combinado das forças helénicas (conhecedoras da experiência de Maratona) resultou num verdadeiro massacre das tropas persas e o próprio Mardónio foi morto em campo, precipitando a debandada geral das falanges e a dimensão do desastre. Esta vitória consistiu, sobretudo, num triunfo da infantaria espartana, que deu provas de uma assombrosa supremacia não somente no espaço grego como em todo o mundo civilizado de então. ${ }^{16}$ A campanha de Plateias constituiu o feito mais notável da unidade helénica, ${ }^{17}$ pois durante três semanas cem mil Gregos resistiram em conjunto aos ataques da cavalaria persa, em obediência ao solene juramento que fizeram antes da batalha de combater até à morte, colocando a liberdade à frente da própria vida (Heródoto, 9.7 2 2).

A vitória de Plateias projetava também, de novo, o triunfo do génio espartano, pela forma como havia liderado os restantes Gregos. Por conseguinte, Pausânias parecia corresponder igualmente à imagem de guerreiro paradigmático que fora atribuída ao tio, nas Termópilas. A euforia da vitória subiu, no entanto, à cabeça do regente espartano, a ponto de os companheiros de armas se verem constrangidos a recordar-lhe que a vitória fora de todos e não dele apenas. Nos anos subsequentes, a hipertrofia da autoestima de Pausânias irá fazer com que a sua atuação se traduzisse num desconforto diplomático crescente, que teria como consequência mais imediata e notável que a liderança da campanha antipersa passasse das mãos dos Espartanos para as dos Atenienses, abrindo assim caminho à afirmação do império ático. Entretanto, Pausânias ia acumulando acusações de

\footnotetext{
16 Facultando assim o contributo determinante para afastar o risco de conquista persa. Cf. Heródoto, 9.58-70.

17 Para usar a feliz expressão de Hammond (1986) 250.
} 
entendimento com os Persas e com os Hilotas, num desafio direto aos interesses espartanos, situação que levou a que o vencedor de Plateias acabasse por definhar à fome num santuário de Atena existente na acrópole de Esparta, de onde fora retirado pouco antes da morte, para evitar a contaminação do local sagrado. Embora viesse a ser honrado, mais tarde, com a dedicação de estátuas de bronze, juntamente com Leónidas, o certo é que a carreira dos dois homens só até certo ponto era comparável: ambos se revelaram excelentes produtos da agoge espartana, mas enquanto Leónidas se manteve fiel até ao fim à causa comum, Pausânias trocou-a pelo ensoberbecimento pessoal, que o conduziria a um fim indecoroso, mostrando assim o diferente destino que esperava um verdadeiro polites quando comparado com quem trocara esse nobre ideal pela cegueira de interesses privados (idiotes) exacerbados. O mesmo conflito contra o invasor persa que cimentara a imagem da eficácia de Esparta e do seu modelo guerreiro, comportava igualmente um aviso sobre o risco de falência do paradigma, se os Lacedemónios se afastassem dos rhemata tradicionais evocados no epitáfio celebrado por Simónides. ${ }^{18}$

Uma vez estabelecidas as linhas gerais da afirmação da ideia de Esparta, desde o universo épico dos heróis de Homero até à descrição da resistência gloriosa dos grandes baluartes da causa helénica em Heródoto, é então altura de abordar o ponto intermédio: a afirmação de Esparta enquanto cidade-estado, expressa através de um código de leis fundacionais, cuja criação é atribuída a Licurgo.

\subsection{A ideia de Licurgo}

Os eventos históricos referidos na secção anterior desempenharam um papel muito importante na projeção da imagem de Esparta enquanto eficaz potência militar, em resultado de um sistema de organização política e de um modelo educacional igualmente eficazes. Do ponto de vista literário, a forma como Heródoto tratou na sua obra o contributo espartano para o esforço de resistência à invasão persa deu, igualmente, um contributo determinante para a sua

\footnotetext{
18 Sobre a ambivalência do exemplo facultado por Leónidas e Pausânias para a afirmação da imagem de Esparta, vide Hooker (1980) 230-231; Cartledge (2007) 163-164.
} 
popularização. A idealização de Esparta continuou depois da sua vitória final sobre Atenas, no termo da Guerra do Peloponeso, em 404, e não seria afetada pela progressiva perda de importância política e militar da Lacedemónia, logo nas primeiras décadas do séc. Iv. Mas talvez o aspeto mais curioso da propaganda espartana resida no facto de esse processo ser alimentado não tanto pelos Espartanos (dada a muito limitada produção literária e cultural da cidade), mas por autores que eram oriundos de Ática ou então que viveram e trabalharam em Atenas. Assim aconteceu com grandes figuras dos sécs. v e iv, como Tucídides, Xenofonte, Platão, Aristóteles, Isócrates e Licurgo (o orador homónimo do legislador espartano). Esta aparente contradição decorrente da circunstância de Esparta ser apresentada como bom exemplo por personalidades mais naturalmente ligadas à sua grande rival, Atenas, poderá explicar-se pelo facto de a democracia radical inspirar fundamentadas renitências em certos meios intelectuais do tempo, que dispensaram simpatias, de resto, aos golpes oligárquicos de finais do séc. v, apesar de não terem contado com grande apoio popular. ${ }^{19}$ Desta forma, contra o fundo de excessos cometidos pelo demos, quando conduzido por chefes mais interessados na promoção pessoal do que na causa pública, o kosmos de Licurgo e a imagem de ordem e disciplina que promovia ganhavam peso como uma alternativa constitucional válida.

Ainda assim, que poderia haver uma discrepância entre os preceitos ditados por lei e a prática efetiva é demonstrado já pelo pormenor de, na Constituição dos Lacedemónios (cap. 14) — um trabalho geralmente atribuído a Xenofonte e que terá sido composto na viragem do séc. v para o IV —-, se denunciar precisamente essa desarticulação, apesar de o opúsculo ser muito favorável a Esparta e à grandeza que as leis de Licurgo lhe teriam trazido. ${ }^{20} \mathrm{E}$ se bem que, nesse período, talvez não houvesse grandes razões para explorar esse binómio (ainda que o comportamento de Pausânias, analisado antes — supra 2.1. — fosse já um exemplo prático dos riscos dessa separação entre teoria e prática), o certo é que, na segunda metade do séc. III, durante os reinados dos reis Ágis IV (244-241) e de Cleómenes III (236-222) foi ensaiada a tentativa, sem sucesso, de recuperar

\footnotetext{
19 Sobre a ideologia política ligada a este período conturbado dos últimos anos da Guerra do Peloponeso e a formação do conceito de patrios politeia, vide infra 3.3. Para um panorama da formação da 'ideia de Esparta' nos autores deste período e de tempos posteriores, vide Hooker (1980) 230-240.

20 Vide MacDowell (1986) 8-14.
} 
o espírito da legislação de Licurgo ${ }^{21}$ - contribuindo talvez para um certo revivalismo da imagem idealizada de Esparta. Não obstante o peso relativo destes constrangimentos, é um facto inegável que a imagem de Esparta continuou (e continua) a alimentar um paradigma capaz de impressionar gerações sucessivas de admiradores e de saudosistas.

Plutarco, que viveu na viragem do séc. i para iı d.C., ilustra de forma particularmente elucidativa as dificuldades que assaltavam quem, como ele, desejasse escrever uma Vida de Licurgo. Vale a pena, por isso, evocar as palavras do prólogo com que abre essa biografia (Lyc. 1.1):

Sobre o legislador Licurgo, não há rigorosamente nada que se possa dizer que não esteja sujeito a disputa: tanto no respeitante ao nascimento, viagem e morte, como em tudo o que se refere à sua atividade na promulgação de leis (nomoi) e de uma constituição (politeia), há tradições historiográficas (bistoriai) muito díspares. De resto, menos consenso se encontra ainda em relação às datas em que terá vivido este homem.

O facto de Plutarco haver decidido tratar em paralelo a existência de Licurgo e a de Numa, o grande legislador dos primórdios de Roma, mostra o grau de importância em que colocava os dois estadistas. Mas a tarefa não se revelava fácil, em especial no que dizia respeito a Licurgo, dada a discrepância dos testemunhos que amplamente haviam abordado já a sua personalidade evasiva, como ilustra o facto impressionante de Plutarco citar, só na biografia de Licurgo, a opinião de várias dezenas de outros autores, cuja obra em muitos casos se encontra hoje perdida. ${ }^{22}$ De resto, na continuação das palavras de abertura (Lyc. 1.2-6), o biógrafo logo explicita a razão de ser das dúvidas enunciadas, ao mencionar as diferentes hipóteses relativas à datação de Licurgo, que alguns autores faziam recuar ora a um tempo preciso, à volta do ano de 776 (datação tradicional da realização das primeiras Olimpíadas), ora a um passado rarefeito como a 'época dos Heraclidas', implicando com isso o tempo dos primeiros reis de Esparta,

21 Essa informação é dada na biografia que Plutarco dedicou a estas duas personalidades (cf. Agis, 4.2, Cleom. 10), baseando-se, ao menos em parte, no relato que deste período fizera Filarco, em obra hoje perdida.

22 Cerca de cinquenta, segundo os cálculos de Cartledge (2003) 57. 
ou ainda ao convívio com personalidades de datação igualmente controversa (como o poeta Homero). De passagem, o biógrafo regista mesmo a hipótese de ter havido em Esparta duas personalidades chamadas Licurgo, que teriam vivido em períodos diferentes mas cuja existência acabaria por ser fundida numa só, com os evidentes problemas e confusões que daí teriam advindo. Apesar destas dificuldades, Plutarco decide avançar com a tarefa de reconstituir a existência de Licurgo, não sem antes esclarecer o critério que vai adotar para proceder à ponderação relativa da informação (Lyc. 1.7):

Ainda assim, apesar de a tradição historiográfica (bistoria) ser marcada por estas incertezas, tentaremos, seguindo as notícias com menos contradições e os testemunhos escritos mais dignos de confiança, apresentar um relato sobre este homem.

A empresa de Plutarco foi, em grande parte, bem sucedida, porquanto a Vida de Licurgo fornece um conjunto de aspetos relativos a esta figura e à Esparta que ele teria construído que não aparecem noutros autores, ao menos com idêntica abundância de pormenores. Isso faz com que a biografia seja uma fonte preciosa de informação sobre a constituição e leis espartanas, mas daí não decorre necessariamente que a existência histórica de Licurgo saia reforçada. De resto, além de outros detalhes biográficos, as dúvidas começam logo pelo próprio nome. Com efeito, Licurgo poderá significar algo como 'produtor de luz' ou então 'servidor do lobo', interpretações que o aproximam de um dos epítetos de Apolo. ${ }^{23}$ Esta natureza 'falante' do nome não favorece, no entanto, a ideia de existência histórica do antigo legislador, sugerindo antes que teria uma natureza mítica, funcionando como uma espécie de projeção do oráculo de Apolo. De resto, já Heródoto (1.65.2-4) se faz eco desta dúvida, ao transmitir a resposta que a Pítia teria dado a Licurgo, em Delfos: ${ }^{24}$

Mas [os Lacedemónios] passaram a uma boa ordem (eunomia) do seguinte modo: Licurgo, um homem estimado entre os Espartanos, dirigiu-se a Delfos para consultar o oráculo e, mal entrava no templo, logo a Pítia lhe diz o seguinte:

23 Vide Manfredini \& Piccirilli (1995) xvII-XviII; Cartledge (2003) 58.

24 Cita-se pela tradução de Ferreira \& Silva (1994). 
Vens, Licurgo, ao meu opulento templo,

Amado de Zeus e de todos os habitantes das mansões olímpicas.

Duvido em proclamar-te deus ou homem,

Mas creio que sejas um deus, Licurgo.

Pretendem alguns que, além destas palavras, a Pítia lhe ditou também a ordem (kosmos) que hoje vigora em Esparta; mas, referem-no os próprios Lacedemónios, Licurgo trouxe-a de Creta quando era tutor de Leobotas, filho de seu irmão, que era rei de Esparta.

Por detrás do oráculo transmitido por Heródoto pode estar uma consulta promovida pelo próprio estado espartano, para que Apolo esclarecesse o sentido das honras que deveriam ser prestadas ao antigo legislador: se heróicas ou divinas. Ora a necessidade de um esclarecimento deste género mostra que a memória relativa à eventual existência histórica de Licurgo já se havia tornado muito ténue, inclusive na época clássica. ${ }^{25}$ Em todo o caso, Pausânias (3.16-6) confirma que ainda no seu tempo (séc. II d.C.) havia em Esparta um santuário que lhe era dedicado. ${ }^{26}$

Mais consistente do que os dados biográficos de Licurgo é a existência de um documento que Plutarco lhe atribui e cuja interpretação é tão importante quanto difícil e controversa. Trata-se de um texto fundacional (escrito em dialeto dórico arcaico), transmitido parcialmente pelo biógrafo e cuja autenticidade enquanto documento é reconhecida pela generalidade dos estudiosos. ${ }^{27}$ Renunciando embora a interpretá-lo agora em pormenor, será com a evocação desse texto que se irá terminar esta abordagem ao mítico fundador da constituição espartana (LyC. 6.1-2; 7-8):

25 O eventual influxo cretense sobre a legislação de Licurgo é explorado também por outras fontes. Para mais pormenores, vide Pérez Jiménez (1985) 281; Ferreira \& Silva (1994) 97.

26 Manfredini \& Piccirilli (1995), XII, comentam aliás que o único dado seguro em relação a Licurgo é a existência deste culto e de outras honrarias que lhe eram prestadas em Esparta.

27 Embora Plutarco sustente, num contexto diferente (Lyc. 13.1-2; cf. [Apophth. Lac.] 227b), que Licurgo não passou a escrito as suas leis, já que preferia que elas ficassem inscritas na consciência derivada da educação (agoge). 
Licurgo empenhou-se tanto neste órgão [scil. o conselho de anciãos ou Gerusia] que chegou ao ponto de trazer de Delfos um oráculo (manteia) que lhe dizia respeito, ao qual dão o nome de Rhetra. Tem o seguinte teor: "Depois de estabelecer um templo em honra de Zeus Silânio e de Atena Silânia, de atribuir as tribos (phylas phylaxanta) e de ordenar as obai (obas obaxanta), de instituir a Gerusia com trinta membros, incluindo os chefes (archagetai), de tempos a tempos deverá reunir a appela [lit. haver apellai] entre Bábica e Cnácion; e assim apresentar propostas e fazer a dispensa, e à assembleia (agora) do povo (damos) vitória e poder [outorgar?]..$^{28}$ [...] Mais tarde, porém, porque a multidão (polloi), com os seus cortes e aditamentos ia subvertendo e forçando as propostas originais, os reis Polidoro e Teopompo ajuntaram por escrito estas palavras à Rhetra: "Mas se o povo (damos) se pronunciar de forma incorrecta, que o dissolvam os anciãos (presbygeneis) e os chefes (archagetai)."29

Antes de reproduzir o documento em análise, Plutarco estava a comentar a forma como as medidas de Licurgo teriam refundado o estado espartano, acentuando, em particular (Lyc. 5.10-14), a importância do conselho de anciãos (Gerusia) e o seu papel de moderador constitucional, prevenindo os riscos de excesso de poder, seja da parte dos reis (a realeza espartana assentava numa diarquia), seja da parte do povo. ${ }^{30}$ Para reforçar a ideia da importância deste órgão (que era na realidade central, independentemente do facto de ser ou não criação de Licurgo), Plutarco diz que o legislador teria procurado sancionar a sua autoridade através de um vaticínio que teria trazido de Delfos e ao qual se dava o nome de Rhetra. Embora, como atrás se disse (supra 2.1.), o termo signifique, antes de mais, 'palavra proferida' ou mesmo 'oráculo', há grande discussão

28 Passo corrupto, de reconstituição e interpretação particularmente disputadas, podendo por isso alterar bastante a compreensão do documento. Para uma ideia das hipóteses em causa, vide aparato crítico de Manfredini \& Piccirilli (1995), 28 com comentário ad loc., e síntese de Pérez Jiménez (1985) 289 n. 37.

29 A reconstituição deste passo é particularmente controversa. Foi adotado o texto de Manfredini \& Piccirilli (1995), 28, cujo amplo comentário foi também tido em conta na análise feita (232-242). Entre as muitas análises motivadas pela interpretação deste documento, vide Pérez Jiménez (1985) 287-290; MacDowell (1986) 3-5; Lévy (2007) 17-26.

30 Esta função de equilíbrio, atribuída já desde a antiguidade a Esparta (e.g. Platão, Lg. 691e-692a), corresponde à noção de que o estado espartano possuía uma 'constituição mista' (com marcas das várias formas de regime) que funcionava como garantia de estabilidade, sendo por vezes comparada à constituição romana, por idênticas razões. 
sobre o significado exato que poderá ter neste contexto: 'acordo verbal', 'pacto', 'declaração solene' ou 'lei' são hipóteses que se encontram entre as várias possibilidades avançadas. ${ }^{31}$

Apesar destas múltiplas leituras e das diferentes motivações que as justificam, há alguns dados que ressaltam deste breve texto e que ajudam a entender a relação estreita entre a ideia de Esparta e a ideia de Licurgo: a crença na sanção divina que acompanha a criação da Grande Rhetra, desde a sua origem, quer o mítico legislador fosse simplesmente um transmissor desses 'ditames proferidos' quer fosse apresentado como seu criador; a importância atribuída ao equilíbrio constitucional criado por estas medidas (onde se destacava o papel moderador do conselho de anciãos) e a necessidade de o preservar da tentação de alterações futuras. Daqui decorre o tratamento deferente dispensado à Grande Rhetra enquanto documento fundacional do estado espartano, bem como a vontade de o salvaguardar através de um sistema de educação que incutisse nos jovens a identificação com os valores que o sustentavam. Estabelecia-se, assim, um nexo de causalidade e de interdependência entre os deuses (em especial Apolo), Licurgo, a Grande Rhetra e a agoge que ajudava a perpetuá-la. Do ponto de vista histórico, é duvidoso que Licurgo tenha de facto existido, sendo ainda mais improvável que a criação da Grande Rhetra possa aliás ser atribuída a uma só pessoa, com esse nome ou com outro. ${ }^{32}$ Ainda assim, a tradição não faculta outra personalidade que pudesse ocupar de forma inequívoca essa posição. ${ }^{33}$ Esta natureza fluida das próprias fontes contribuiu seguramente para projetar a visão mítica de Licurgo como primeiro responsável pela constituição que daria a Esparta a imagem de cidade-quartel e de eficaz máquina de guerra ao serviço incondicional da pólis. Licurgo como Esparta acabam por ser, em última análise, faces da mesma moeda e por estimular o mesmo processo de aproveitamento ideológico que os guindará -

\footnotetext{
31 Vide Manfredini \& Piccirilli (1995) 232-233.

32 De resto, ainda que com a intenção de reforçar a imutabilidade da Rhetra, o próprio texto sugere uma criação coletiva, conseguida por um aperfeiçoamento progressivo, como se deduz da informação de que os reis Polidoro e Teopompo teriam ajuntado uma nova cláusula precisamente para prevenir a tentação de futuros cortes e aditamentos.

33 Quílon será, igualmente, uma figura carismática, a ponto de ser presença usual nas listagens de Sete Sábios, mas os dados da sua existência estão também sujeitos a um processo de amplificação lendária, apesar de ele ter por certo maior consistência histórica do que Licurgo. Sobre o papel de Quílon entre o grupo de Sete Sábios, vide Leão (2010a).
} 
enquanto criador e criatura - ao plano de paradigmas que animarão grupos de apreciadores e de detratores ao longo de toda a história do mundo ocidental, com especial destaque para momentos em que o debate de ideias se torna mais intenso e mais emotivo. ${ }^{34}$

34 Sobre a presença de Licurgo e de outros estadistas gregos no ambiente intelectual da Revolução Francesa, vide Ferreira (2010). 


\section{IDEOLOGIA E IMPÉRIO O TEMA DA AUTOCTONIA E DA PATRIOS POLITEIA NA ATENAS DO SÉC. V}

Em meados do séc. v, numa altura em que o império ático e o regime democrático atingiram, por assim dizer, o seu ponto de equilíbrio mais notável, Péricles avançara com uma proposta legislativa que parecia corresponder (e correspondia, na verdade), a um certo recuo no alargamento no acesso ao poder que, ao menos desde Sólon, tinha vindo a marcar de forma crescente a sociedade ática. A sua lei relativa à cidadania, de 451/0, obrigava a que ambos os progenitores fossem já cidadãos, como condição para que o mesmo estatuto transitasse para a respetiva prole. Esta medida vem mencionada brevemente e de forma lacunar na Constituição dos Atenienses. ${ }^{1} \mathrm{O}$ autor do tratado justifica a medida como forma de controlar o "elevado número de cidadãos", o que parece ser um indício claro de que os Atenienses pretenderiam circunscrever, a um círculo de pessoas menos abrangente, as prerrogativas cívicas facultadas pelo governo democrático. Com efeito, a democracia do séc. v alargara, como nenhum outro regime, a base de participação da soberania popular, mas também não poderia aumentar indefinidamente o número de cidadãos, pois de outra forma correria o risco de pôr em causa a própria natureza de uma democracia direta e participativa, bem como o apetecível acesso à distribuição dos proventos. ${ }^{2}$ Como tal, ao mesmo tempo que o conceito de cidadão se apurava e crescia também a importância da Ática na Hélade (tornando mais apetecível o estatuto

\footnotetext{
1 Ath. 26.4.

2 Como a mistoforia, isto é, o pagamento pelo desempenho de determinados cargos públicos - medida que se encontrava em vigor possivelmente havia já alguns anos e que teria sido proposta pelo mesmo Péricles. Sobre esta questão vide Ferreira \& Leão (2010) 193-199.
} 
de polites ateniense), aumentaram também os entraves à inclusão direta de novos elementos de pleno direito, aperfeiçoando-se, por conseguinte, as formas de exclusão.

\subsection{Cidadania e autoctonia}

A supremacia de Atenas dentro do mundo grego era uma das consequências mais visíveis da Simaquia do Delos. Criada em 477, ainda no rescaldo das Guerras Medo-persas, a Simaquia de Delos começou por ser uma aliança voluntária das cidades do Egeu e da Ásia Menor com Atenas, de forma a defenderem os interesses gregos e manterem as forças persas à distância. No entanto, essa confederação vai permitir à cidade de Atenas estabelecer um verdadeiro império económico, baseado no poder a na eficácia da frota, e alargar a influência política, favorecendo a instauração de democracias nas póleis aliadas. ${ }^{3}$ Para atenderem aos objetivos enunciados, as cidades aliadas contribuíam ora com navios ora com dinheiro; as contribuições monetárias passavam a integrar o tesouro comum, que ficara depositado, inicialmente, na sede da Simaquia, em Delos. ${ }^{4}$ Em 454, este fundo é transferido para Atenas, como garantia de melhor proteção contra eventuais ataques, mas esta decisão constituía igualmente um indício claro do imperialismo crescente da cidade. Por outro lado, não muito depois, Péricles levaria a Assembleia a votar que essa reserva de dinheiro fosse utilizada para reconstruir os templos, sobretudo os da Acrópole, que tinham ficado à mercê do saque persa. Esta resolução, que os aliados podiam, com todo o direito, acusar de abusiva, ${ }^{5}$ vai, no entanto, criar a oportunidade para grandes realizações artísticas como o Pártenon ou as estátuas da deusa Atena por Fídias. Estas grandes obras, ao mesmo tempo que constituem uma importante fonte de emprego para

\footnotetext{
3 A este movimento se contrapõe a Simaquia do Peloponeso, liderada por Esparta, que procurava estabelecer oligarquias na sua área de influência política e militar. Este facto vai acentuar o dualismo de forças na Hélade, que desembocará naturalmente na Guerra do Peloponeso, em 431-404.

4 Tucídides, 1.96. Para um quadro cronológico relativo a este período, vide Gomme (1945-1956) I.394-396.

5 Na verdade, as tentativas, promovidas sobretudo pelos aristocratas de algumas das cidades aliadas, para se afastarem da Simaquia de Delos a fim de aderirem à do Peloponeso, foram sempre duramente reprimidas por Atenas.
} 
muitos assalariados (evitando, assim, que se criassem situações de agitação e revolta internas), são também a face visível da grandeza de Atenas.

No entanto, à medida que o tempo foi diluindo a urgência da ameaça medo-persa que justificara a criação da Simaquia de Delos, Atenas precisou de encontrar outras formas de fundamentar, no plano ideológico, não apenas a supremacia moral do regime democrático, como ainda o carácter natural e necessário da sua hegemonia militar, política e económica. É a esta dupla procura de legitimação interna e externa que o mito da autoctonia ${ }^{6}$ veio responder, começando a afirmar-se ao longo do séc. v, provavelmente pouco tempo depois de Péricles ter feito aprovar a já mencionada lei relativa ao direito de cidadania.? Apesar de o mito da autoctonia vir a ser particularmente distintivo dos Atenienses, a verdade é que outras póleis o reclamavam também para si. De resto, num passo muito interessante, Diodoro Sículo acha mesmo que todos os povos tendiam a cultivar essa visão idealizada do passado, fossem eles gregos ou bárbaros, (1.9.3):

Sobre a antiguidade do género humano existe controvérsia não apenas entre os Helenos, mas também entre muitos povos bárbaros, pois dizem de si mesmos que, entre todos os homens, eles é que são os autochthones e os primeiros inventores de quanto é útil para a vida, e ainda que foram os eventos por eles realizados os primeiros no tempo a serem merecedores de registo.

Diodoro é um autor que escreve no séc. I, portanto num período em que o termo autochthon já tinha vários séculos de utilização, sendo que o sentido mais neutro correspondia a dizer de alguém que era um 'natural da terra' ou 'nativo'. A interpretação metaforicamente mais forte, e registada sobretudo a partir de finais do séc. v, é a de 'nascidos da própria terra' como forma de designar os que 'haviam brotado do próprio solo', estabelecendo assim uma ligação direta

\footnotetext{
6 'Autoctonia' é um termo de criação moderna, pois os Gregos nunca chegaram a usar este substantivo abstrato, utilizando apenas autochthon e a forma de plural autochthones para designar o conceito agora em análise. Vide Miller (1982) 13. Na abordagem do conceito de autoctonia, retoma-se o essencial dos argumentos usados em Leão (2010b).

7 Isso não significa que a ideia da ligação entre os Atenienses e o imaginário ctónico não tivesse um tratamento, a nível do culto, já bastante anterior, como acontecia com as figuras de Cécrops e, em especial, com as de Erecteu e de Erictónio, entendidos no plano do mito como antepassados dos Atenienses. Sobre esta questão, vide Loraux (1984) 35-73; Bearzot (2007) 9-13; Valdés Guía (2008).
} 
de filiação com o chão pátrio. ${ }^{8}$ Porém, num estudo muito citado a propósito destas questões, Rosivach ${ }^{9}$ demonstrou que autochthon não tinha inicialmente esse significado, começando por ser usado para designar um povo que, desde tempos imemoriais, 'habitara sempre no mesmo solo', portanto que nunca fora um colono ou invasor. Desse conceito de 'estar fixado há muito tempo no mesmo lugar' decorreram depois outras implicações, que se encontram, de resto, espelhadas no texto de Diodoro atrás citado: a ideia de um povo ser o primeiro inventor (protos beuretes) das várias technai, de cultivar a terra e o grão (conquista inseparável do abandono do nomadismo), de ser capaz de levar a cabo feitos assinaláveis e de os registar para a posteridade — em suma de fazer tudo aquilo que distingue e marca um estádio civilizacional mais avançado.

Todas estas qualidades positivas remetem para um padrão civilizacional que facilmente se identificaria com o patamar cultural de Atenas, embora as primeiras ocorrências deste termo, aplicado a um povo, não sejam ainda usadas para designar a Ática. Com efeito, essas referências surgem nos relatos históricos de Heródoto e de Tucídides, mas é significativo registar que nenhum dos autores aplica a designação de autochthones a Atenas, talvez por terem a consciência clara de que na região ática havia um bom núcleo de antigos imigrantes (epelydes) de outras terras. ${ }^{10}$ Ainda assim, Heródoto coloca na boca do embaixador ateniense junto do tirano Gélon de Siracusa a afirmação de que os Atenienses (7.161) "eram o povo mais antigo e o único, entre os Helenos, a não ter mudado de local". E Tucídides afirma também que, "a Ática pelo menos desde há muito tempo foi poupada a lutas internas, devido à pouca profundidade do seu solo e por ter sido sempre habitada pelo mesmo povo". ${ }^{11}$ Ou seja, ainda que os dois historiadores não apliquem o termo autochthones aos Atenienses, na verdade não deixam de reconhecer que este povo reúne as condições para corresponder à essência do conceito nesta aceção inicial: a de serem um povo antigo e que havia vivido

8 Nesta aceção, pode ser usado como sinónimo de gegenes (e.g. Platão, Sph. 247c e 248c).

9 (1987) 297-301.

10 Blok (2009) 251-252, 254-255 e 263-264, já regista e avança esta possível explicação para a aparente 'relutância' de Heródoto e Tucídides em designar os Atenienses por autochthones. De resto, Heródoto (1.144-147) comenta com acentuada ironia o carácter misto da população iónica, que se gloriava, pelo contrário, de ter uma ascendência pura.

11 1.2.5. Pelo contrário, os Dórios teriam conquistado o Peloponeso oitenta anos depois da Guerra de Troia, guiados pelos Heraclidas; cf. Tucídides, 1.12.3. Para os passos de Tucídides, usa-se a tradução feita por Fernandes \& Granwehr (2010). 
sempre na Ática. O facto de na sociedade ateniense haver elementos que eram, pelo contrário, epelydes não afeta a natureza do ethnos ateniense no conjunto e permite não só dar espaço a alguma capacidade de inclusão total ${ }^{12}$ (registada tanto a nível histórico como mítico), da mesma forma que abre caminho a graus parciais de exclusão e de inclusão, como acontece, por exemplo, com a situação de estrangeiros e metecos. ${ }^{13}$

Portanto, de uma utilização por vezes ainda renitente do termo autochthones para designar os Atenienses enquanto povo que 'habitara desde tempos imemoriais o mesmo lugar', o conceito sofreu uma expansão que daria ao mito da autoctonia um sentido mais idealizado e propagandístico, traduzindo-se na aceção altamente metafórica de um povo que 'brotara do próprio solo pátrio'. Para essa evolução, contribuiu também a tradição que, já em Homero (Il. 2.546-548), fazia dos Atenienses um povo descendente de Erecteu — figura que, tal como Erictónio, contribui para uma forte ligação à ideia de 'nascer do solo'. Embora este mito seja independente da autoctonia e conhecesse uma exploração bastante mais antiga no plano do culto e nos motivos pictóricos utilizados na cerâmica ática, terá ainda assim contribuído para expandir a leitura do termo autochthon, ao favorecer a ideia de uma ligação congénita com a terra.

Neste processo de amplificação semântica, tiveram também um papel importante os discursos fúnebres (epitaphioi logoi), precisamente pela forma como conjugam um momento de grande tensão emocional coletiva, com a necessidade de exaltação patriótica e o simbolismo de devolver os corpos dos soldados caídos à terra nutriz. ${ }^{14}$ Este tipo de oratória política e epidíctica parece ter sido bastante cultivada, embora quase todos esses discursos se tenham perdido. Do que se conserva, tem um interesse particular a famosa oração fúnebre que Tucídides (2.35-46) coloca na boca de Péricles, e à qual se voltará mais adiante (infra 3.3), bem como os Epitaphioi atribuídos a três dos oradores do cânone: Hiperides 6, Demóstenes 60 e Lísias 2 - sendo que estes dois

\footnotetext{
12 De resto, que essa consciência histórica havia cristalizado na própria matriz civilizacional ática mostra-o o facto de, no plano do mito, os Atenienses gostarem de se apresentar como um povo acolhedor e com elevado sentido de justiça, recetivo por conseguinte a socorrer e a integrar elementos que haviam sido rechaçados por outras sociedades - como o universo da tragédia ilustra de forma insistente. Forsdyke (2005) 234-239.

13 Sobre esta questão, vide infra 3.2 .

14 Embora num contexto diferente, Isócrates exprime de maneira paradigmática esta noção (Panegírico, 4.25: 'a nós apenas, entre os Helenos, cabe chamar nutriz, pátria e mãe à própria [terra]'.
} 
últimos são considerados frequentemente, mas não de forma unânime, trabalhos espúrios. ${ }^{15}$ A estes há que acrescentar o Menéxeno de Platão, um trabalho interpretado como uma espécie de tour de force ao qual se atribuem geralmente propósitos paródicos, mas que não deixará ainda assim de constituir um exemplo válido dos topoi explorados nas estratégias de glorificação de Atenas.

Para os objetivos deste estudo, não cabe agora evocar em pormenor os momentos que marcaram a evolução do termo autochthon que, quando ocorre nestes contextos, apesar de continuar a manter o sentido inicial de 'habitar desde sempre no mesmo lugar', aparece também com frequência na aceção expandida de 'brotar da terra'. ${ }^{16}$ Ainda assim, valerá a pena recordar um pequeno passo do Epitaphios atribuído a Demóstenes, pois constitui um exemplo elucidativo da forma como os vários temas ligados ao mito da autoctonia se interpenetram (60.4):

A nobreza (eugeneia) destes homens tem sido reconhecida, desde tempos imemoriais, pela humanidade inteira. Pois cada um deles e dos seus antepassados mais remotos pode traçar a ascendência, um a um, não apenas ao pai biológico, mas também a toda a pátria (patris), em comum, à qual se diz que pertencem como autochthones. Com efeito, somente eles, entre toda a humanidade, brotaram dela e, depois de nela habitarem, a passaram aos seus descendentes. Por isso, é com justiça que se pode assumir que os que vieram como emigrantes (epelydes) para estas póleis, e se designam por cidadãos iguais (politai homoioi), são na verdade comparáveis aos filhos adotivos (eispoietoi paides), enquanto aqueles são cidadãos legítimos (gnesioi politai), nascidos da própria pátria.

O orador começa por dizer que a origem comum é dada não tanto pelo solo, mas pela própria patris da qual brotaram ou na qual sempre viveram (pois neste passo autochthones parece oscilar entre os dois sentidos básicos). O orador faz depois uma comparação entre esses verdadeiros filhos da pátria, nascidos de forma legítima (gnesioi politai) e os filhos de antigos emigrantes (epelydes), os quais, sendo embora considerados cidadãos de igual estatuto jurídico (politai

15 Cohen (2000) 94-95 e n. 99.

16 Cohen (2000), 96-102, apresenta uma sugestiva síntese das principais variantes que ocorrem nestes textos. 
homoioi), parecem estar afetivamente colocados num estádio um pouco inferior, como se fossem filhos adotivos (eispoietoi paides). Ora é interessante notar que, nessa relação dialógica com o passado distintivo de uma ascendência pura, o orador inscreva também uma série de três princípios, marcados pela lógica da exclusividade: brotar da própria terra, habitá-la com um sentimento de plena legitimidade e, finalmente, transmiti-la aos descendentes que brotaram desses mesmos cidadãos. Esta ideia de uma ligação à terra com um sentimento de propriedade não tem colhido, regra geral, a atenção devida dos estudiosos que abordaram a questão da autoctonia, embora seja um aspeto igualmente importante, até pela maneira como permite esclarecer certas peculiaridades ligadas à posse da terra (enktesis), um direito conotado também fortemente com uma inclusão parcial de metecos e estrangeiros, que poderia (ou não) conduzir à concessão final do estatuto de cidadania. ${ }^{17}$

\subsection{Direito de enktesis}

Uma das formas de inclusão incompleta de estrangeiros consistia em conceder-lhes o estatuto de meteco. Em estudos mais recentes, o meteco deixou de ser visto como alguém detentor de uma posição privilegiada entre os estrangeiros com autorização de residência, para ser identificado com todo o xenos que haja optado por fixar o domicílio numa nova pólis (xenos metoikos ou simplemente metoikos). Em consequência, o registo na qualidade de meteco não será tanto um privilégio que se espera alcançar, mas antes uma formalidade que se torna forçoso observar para estadias prolongadas, obrigação essa que acabaria por ser extensível, de resto, aos próprios escravos libertados. ${ }^{18}$ Este entendimento reflete-se na própria interpretação do termo metoikos, que deve traduzir-se não tanto permeado pelo princípio da hospitalidade ('alguém que fixa a residência entre nós'), mas antes com as tonalidades mais neutras de 'alguém que altera a residência' e que é, em suma, um 'imigrante'. Do ponto de vista jurídico,

\footnotetext{
17 Esta noção encontra-se claramente operativa no Íon de Eurípides, uma tragédia que explora de maneira muito crítica as contradições do mito da autoctonia, precisamente pelos níveis de exclusão que pode promover. Sobre esta questão, vide Leão (2011a) e infra 4.3.1.

18 Whitehead (1977) 6-10; Todd (1995) 195.
} 
o metoikos não era um cidadão, mas tinha a vantagem de estar legalmente integrado na comunidade e, por isso, seria de esperar que gozasse de um grau de proteção superior ao de um xenos não residente. ${ }^{19}$

Ainda assim, uma pólis poderia também optar por conceder alguns privilégios especiais a estrangeiros (que nem sempre teriam já o estatuto de metecos). Entre essas marcas de distinção, há duas que se destacam pelas consequências práticas que acarretavam: a isoteleia e a enktesis. A isoteleia ('igualdade no pagamento de impostos') tornava os metecos semelhantes aos cidadãos no que ao pagamento de taxas dizia respeito e talvez implicasse também a isenção do metoikion, com o significado que isso teria, mais a nível simbólico que financeiro. ${ }^{20}$ Alguns estudiosos defendem que os metecos poderiam ser recompensados igualmente com a isenção total de impostos (ateleia), mas este dispositivo seria de aplicação muito rara. O segundo aspeto que merece destaque diz respeito ao direito à posse de bens imóveis (enktesis) em território ático. Em princípio, apenas os cidadãos de plenos direitos gozariam desta prerrogativa, pelo que os metecos poderiam somente ser arrendatários. A concessão do direito à enktesis, fosse de terra e de casa ou apenas de casa, revestia-se portanto de um poderoso valor emblemático. Havia ainda outros títulos distintivos, que tinham um significado honorífico e não implicavam, só por si, a atribuição de privilégios, se bem que estes pudessem também ser concedidos, de forma indireta. É o que acontece com os estatutos de euergetes ('benfeitor') e proxenos ('hóspede público'). O segundo termo constituía, originariamente, a designação oficial de um representante local de interesses estrangeiros, de certa forma comparável a um cônsul, mas com a diferença de que continuava a habitar na sua pólis de origem. Porém, ao longo do séc. Iv foi usado de forma crescente como simples título honorífico concedido a metecos residentes em Atenas. ${ }^{21}$

19 Se bem que as fontes nem sempre esclareçam de que tipo de estrangeiro estão a falar, dificultando assim a identificação dos limites legais precisos do estatuto de metoikos.

20 Em Atenas, o metoikion era um imposto próprio dos metecos, de doze dracmas anuais para o homem e de seis para a mulher, cujo não pagamento poderia levar à escravatura. Esta possibilidade de escravatura por dívidas mostra que os metecos não possuíam a mesma proteção legal que os cidadãos. A severidade da punição deve justificar-se não pelo montante envolvido (que era relativamente baixo), mas pelo seu carácter simbólico, enquanto sinal visível da posição subordinada do meteco - além de que o não pagamento do metoikion poderia ser interpretado como uma tentativa velada de usurpação de cidadania. Vide Whitehead (1977) 75-76.

21 Para uma listagem destes e de outros privilégios menores atribuídos a estrangeiros, vide MacDowell (1978) 78-79. Sobre o estatuto do próxeno, vide Ferreira (2004). 
Entre estes privilégios, a isoteleia e a enktesis correspondiam, na prática, a elementos característicos do estatuto de polites, mas que tanto poderiam ser concedidos de forma independente, como ainda constituir etapas numa eventual concessão futura da cidadania plena. ${ }^{22}$ Atendendo à enorme importância económica que os estrangeiros e em especial os metecos detinham em cidades abertas ao comércio, como Atenas, chega a parecer contraditório que essas pessoas não tivessem capacidade para deter direito de propriedade sobre casas e terras, sendo assim impedidas, por exemplo, de contrair empréstimos com garantia real sobre esses mesmos bens. ${ }^{23}$ Daí que um autor como Xenofonte (Vect. 2.6) possa sugerir que uma das formas de tornar Atenas mais atrativa para os visitantes seria a de conceder com mais facilidade o direito de enktesis a metecos. ${ }^{24}$ Apesar de as inscrições registarem com alguma frequência a outorga do direito de enktesis, na verdade as póleis encaravam a concessão desse privilégio como uma exceção. ${ }^{25}$ Por outro lado, o facto de as inscrições terem a preocupação de registar que o direito seria concedido a determinada pessoa e "aos seus descendentes" tem sido interpretado como sinal de que esse direito não se tornava automaticamente hereditário - o que constitui mais um indício do seu carácter defensivo e extraordinário.

Uma limitação deste cariz respeitante aos direitos de propriedade deve entender-se, precisamente, no quadro da importância simbólica atribuída à posse da terra, de que o mito da autoctonia constitui provavelmente a expressão mais paradigmática. Com efeito, as várias interpretações de autochton antes analisadas (supra 3.1), para o caso específico de Atenas, insistem na ideia de que o estatuto de um polites de ascendência pura assentava numa ligação primordial, continuada e mesmo congénita entre o cidadão e o solo pátrio, que pode por isso ser visto como 'terra-mãe', seja porque alimentou os seus filhos desde o nascimento, seja porque está disposto a recebê-los de volta no seu seio depois

22 Meyer (1993) 113 n. 41; Lambert (2006) 115-116.

23 Harrison (1968-1971) I.237-238. Um pouco antes (p. 153), o mesmo estudioso salienta que nenhum xenos ou metoikos poderia receber um bem imóvel por testamento, a menos que lhe tivesse sido concedido o privilégio da enktesis.

24 A inscrição n 77 , datada de 338/7 a.C., transcrita e analisada por Rhodes \& Osborne (2003), 380-384, constitui um elucidativo exemplo dessa prática, com frequência atribuída em conexão com o estatuto de proxenos. Para outros exemplos de concessão de enktesis, vide ib. inscrições n ${ }^{\circ}$ 75, 94 e 95. Pečirka (1966) é o estudo de referência sobre a fórmula de concessão da enktesis.

25 Biscardi (1982) 189-190. 
de mortos. E isto é válido quer se interprete autochthon como 'o que vive na mesma terra desde há muito tempo' ou, na versão mais elaborada, como 'o que brotou do próprio solo'. O passo do discurso fúnebre atribuído a Demóstenes (60.4), e comentado na secção anterior, é disso mesmo um claro exemplo. E o Menéxeno de Platão, pese embora a sua natureza paródica, está profundamente permeado por este imaginário. ${ }^{26}$ Por isso, valerá a pena citar um pequeno passo desta última obra, por ser particularmente elucidativo da relação implícita entre cidadania, autoctonia e posse da terra (237b-237c):

No que se refere à nobreza de nascimento (eugeneia), a sua primeira reivindicação é de que, na origem, os seus antepassados (progono $i$ ) não eram imigrantes (epelys), nem os filhos deles poderiam ser vistos como estrangeiros (metoikein) nesta terra, por terem vindo de outras paragens; pelo contrário, são autochthones a morar e a viver na sua verdadeira pátria; e não foram alimentados por uma qualquer madrasta (metryia), como acontece com outros, mas pela terra-mãe (meter chora) onde habitam, a qual os gerou e alimentou e que hoje, na hora da sua morte, os acolhe de novo no seio do lar. É assim da maior justiça que comecemos por honrar essa mãe (meter), pois ao fazê-lo estamos igualmente a honrar a nobreza de nascimento (eugeneia) destes heróis.

Mesmo concedendo que Platão tem por objetivo satirizar os topoi correntes na estratégia de glorificação de Atenas, em especial em contexto fúnebre, ainda assim o texto não deixa de ser ilustrativo do imaginário real que lhe serve de referência, pois a paródia só funciona quando existe um modelo efetivo com o qual possa estabelecer uma relação dialógica. E esse modelo remete para a importância que a noção de uma relação privilegiada com a terra nutriz detinha no imaginário grego em geral e no ateniense em particular. E se é inegável que essa ideia se desenvolveu ao serviço da propaganda política e ideológica no mito da autoctonia, a sua presença pode detetar-se também no substrato sociológico que justifica uma prerrogativa específica do estatuto do polites: o direito de possuir terra e os bens que nela assentam as suas fundações (as

26 Cf. 237a-238d. 
casas), bem como a capacidade de os transmitir aos descendentes. ${ }^{27}$ Isso ajuda a entender a relevância atribuída à enktesis, que só era concedida a elementos estranhos ao corpo cívico na sequência de um procedimento destinado a honrar alguém com especial deferência. Com efeito, se a terra pode ser considerada mãe - em sentido metafórico e também denotativo - torna-se evidente que um filho verdadeiro, consciente e dedicado não a pode alienar de ânimo leve.

\subsection{Patrios politeia}

Ao analisar-se o desenvolvimento do tema da autoctonia (supra 3.1), foi dito que essa ideologia se refletiu, de forma bastante insistente, no imaginário ligado aos discursos fúnebres - um subgénero que encontra um modelo de eleição no famoso discurso transmitido por Tucídides (2.35-46), mas que teria sido pronunciado por Péricles, em honra das primeiras vítimas da Guerra do Peloponeso (431-404). Esta célebre oração é, antes de mais, um hino à democracia e à soberania da lei, enquanto marcas distintivas de Atenas, uma cidade que, por isso mesmo, é apresentada como verdadeira 'Escola da Hélade'. ${ }^{28}$ Por isso se torna tão significativo que, na antecâmara de fazer o elogio dessas elevadas qualidades civilizacionais, Péricles tenha o cuidado de enquadrar o progresso de Atenas dentro das características essenciais observadas para o tema da autoctonia (2.36.1-2):

Vou falar primeiro dos nossos antepassados pois é justo e apropriado que em ocasião como a presente lhes seja dada a distinção desta memória. Na verdade até hoje em sucessivas gerações eles viveram sempre nestas terras e graças ao seu esforço legaram-nas livres à posteridade. E se aqueles merecem louvor, mais ainda os nossos pais que ganharam, não sem dificuldade, para além daquilo que tinham recebido, o império que agora temos e que eles nos legaram como herança.

27 Estes princípios encontram-se também operativos no Íon de Eurípides, mas dada a complexidade que o tema detém nesta tragédia, irá receber uma abordagem específica (infra 4.3.1), enquanto ilustração da forma como o teatro espelhava uma relação estreita com a pólis e com os seus politai.

28 2.41.1: "Em resumo, eu digo que não só a nossa cidade serve de exemplo a toda a Hélade mas também, na minha opinião, cada um de nós, Atenienses, como indivíduo, na maioria dos casos, é exemplo do cidadão que cuida de si próprio com brandura e habilidade". 
Com efeito, embora Péricles (através das palavras de Tucídides) não refira diretamente o conceito de autoctonia, ele está implícito na ideia de que os antepassados mais remotos dos Atenienses habitavam, desde há sucessivas gerações, na mesma terra, a qual foram capazes de transmitir aos seus descendentes, como uma herança, mantendo sempre o mesmo estatuto de liberdade. Esse princípio serve, no entanto, de mote para que o estadista possa expandir o progresso alcançado pelos Atenienses, ao registar a grandeza das conquistas mais recentes - o império a duras penas conseguido pelos seus pais e em cuja defesa haviam perecido os familiares dos destinatários do discurso fúnebre, dando um exemplo de heroísmo que todos deveriam honrar com idêntica dedicação à causa comum, agora que estavam em pleno conflito.

A evolução dos acontecimentos haveria, no entanto, de responder com ironia aos propósitos de Péricles. De facto, iniciada a Guerra do Peloponeso, os Atenienses começaram por seguir, ainda que relutantes, a estratégia delineada por Péricles de se recolherem dentro das muralhas. Uma vez que a cidade se encontrava ligada ao Pireu por muralhas, era, assim, assegurado o abastecimento de víveres por via marítima, onde a supremacia da frota ateniense era clara. Porém, esta medida obrigava a tributar um preço elevado. Antes de mais, no moral da população, a quem se tornava muito custoso não só abandonar as casas e os campos ao inimigo, como assistir, do interior das muralhas, ao espetáculo da destruição periódica da sua terra. Se, nalguns agricultores, isso poderia fazer despertar o desejo da paz, na maior parte acicatou apenas o ódio contra o inimigo e o desejo de combater. A este cenário desolador vinha juntar-se a concentração excessiva de pessoas no interior da cidade, alojadas em condições sanitárias muito deficientes, ${ }^{29}$ que favoreceram o aparecimento da peste. ${ }^{30}$ Péricles viria, precisamente, a ser uma das vítimas da epidemia, em 429, quando eram já decorridos dois anos e seis meses de conflito. Com a sua morte, ficara desimpedida a porta que permitiria a 'condutores do povo' (demagogos) menos cientes do interesse público subir ao poder e levar a cidade a tomar decisões irrefletidas e de consequências por vezes desastrosas.

$292.17 .1-3$.

30 2.47-54. O relato de Tucídides mostra todo o dramatismo da calamidade, bem como as consequências que a peste teve sobre a psicologia coletiva dos Atenienses, favorecendo o desrespeito quer dos ditames religiosos quer das leis cívicas e morais. 
Com efeito, o longo conflito entre Gregos que deu corpo à Guerra do Peloponeso viria a ter repercussões políticas e culturais muito importantes, sendo aliás recorrente encontrar, na expressão literária desse período, ecos das vicissitudes provocadas por esta luta fratricida. Com efeito, a dimensão 'política' do teatro ático (infra 4.1), em particular da chamada 'comédia antiga', leva a que as comédias de Aristófanes possam inclusive servir de guia para compreender o ambiente que se vivia na Atenas do último quartel do séc. v e do sentimento de desencanto que iria criar condições para que o regime democrático fosse posto abertamente em causa, cerca de um século depois da sua criação. De resto, as duas tentativas oligárquicas para derrubar a democracia radical (em 411 e em 404) devem ser entendidas como resultado do cansaço e das contrariedades decorrentes desse longo conflito fratricida. Portanto, além de usufruírem da oportunidade criada por campanhas militares mal sucedidas, os fautores desses golpes vão, igualmente, aproveitar a vontade, sentida por muitos dos Atenienses acantonados no interior das muralhas, de voltarem ao status quo anterior à guerra. A este sentimento saudosista, os revolucionários souberam associar também determinadas tonalidades políticas, que correspondiam ao conceito polissémico da patrios politeia, isto é, da propaganda ideológica ligada à 'constituição ancestral' que se tornava urgente recuperar para inverter a linha descendente em que o regime democrático tinha entrado. ${ }^{31}$

Esse sentimento é particularmente visível na sequência dos desencantos provocados pela entrada de Alcibíades, familiar de Péricles (que fora aliás seu precetor), na cena política ateniense. A sua crescente influência na vida política de Atenas permitiu-lhe conseguir que, em 415, a Assembleia aprovasse uma empresa militar em larga escala à Sicília, com o pretexto de auxiliar as cidades democráticas atacadas por Siracusa, mas cujo real objetivo consistia em alargar o poder ático para ocidente. ${ }^{32}$ A proposta comportava alguns riscos, de que o mais sério correspondia a criar uma nova frente de combate, quando seria

\footnotetext{
31 Embora a expressão patrios politeia seja a que melhor dá corpo a este conceito, nas fontes ocorrem outras variantes que têm em comum a ideia de recuperar um modelo 'pátrio' 'ancestral', que espelhasse o verdadeiro espírito cívico que fizera a grandeza da Ática. Assim acontece com termos como patrioi nomoi ('leis ancestrais') ou com a disposição difusa kata ta patria ('de acordo com os preceitos ancestrais'). Sobre a natureza e implicações políticas deste ideal propagandístico, vide Leão (2001), 43-72, análise da qual se recuperam aqui somente as conclusões finais.

32 Tucídides, 6.1; 6.6; 6.8-26.
} 
mais aconselhável concentrar as forças. Havia de facto razões para temer o envolvimento num projeto que, a correr bem, poucas vantagens traria e, caso contrário, poderia acarretar graves consequências, uma vez que o investimento de fundos e de pessoas seria muito elevado, como viria a acontecer. Por outro lado o envolvimento, legítimo ou não, de Alcibíades num duplo escândalo (mutilação dos Hermes e paródia aos Mistérios de Elêusis), mesmo antes da partida para a Sicília, viria minar a sua autoridade e preparar o futuro desaire. ${ }^{33}$

Com efeito, ao alinhar na expedição à Sicília e ao condenar depois o seu grande impulsionador, a soberania popular cometia erros sucessivos, que iriam abalar fortemente a credibilidade nas suas instituições. A Ekklesia, além de não escutar as sensatas objeções de Nícias, acabaria por elegê-lo, contra a vontade do próprio, para ser um dos generais encarregados de comandar a expedição. Por outro lado, o demos deixara-se primeiro entusiasmar por Alcibíades, para em seguida lhe retirar o apoio e chamá-lo da Sicília, privando a armada do único general que a poderia conduzir à vitória e dotando o inimigo de um conselheiro que levaria à ocupação e fortificação de Decelia, em território ático e a escassos quilómetros de Atenas. Este posto avançado, além de constituir uma ameaça constante à cidade, permitia ao inimigo paralisar o funcionamento das minas de Láurion. Por último, quando o bom senso aconselharia a abandonar o propósito da expedição, o demos optou por enviar reforços, o que apenas serviu para agigantar o clamoroso desastre de 413.

Se, até ao início da Guerra do Peloponeso, o equilíbrio e sucesso da democracia ateniense, guiada pelo espírito clarividente de Péricles, haviam feito com que as fissuras no tecido social fossem reduzidas ao mínimo, a derrapagem económica e insucessos militares como a expedição à Sicília vieram pôr em causa a eficácia da constituição democrática e reacender a contestação e as lutas políticas. O primeiro sinal inequívoco de crise aconteceu, portanto, em 413. A situação era extremamente grave. Os Atenienses haviam criado uma nova frente de batalha a ocidente, com a agravante das pesadas baixas no potencial bélico e de a frota ter perdido a tradição de invencibilidade. O momento era, portanto, favorável quer à revolta dos aliados desejosos de se libertarem do imperialismo

\footnotetext{
33 Para mais pormenores sobre o envolvimento de Alcibíades neste processo, vide Ferreira \& Leão (2010) 209-234.
} 
ático, quer a um ataque em massa dos inimigos. Contudo, Atenas surpreenderia o mundo grego com a sua capacidade de regeneração, implementando medidas económicas drásticas e algumas inovações políticas. Ainda assim, a crescente contestação à democracia radical iria levar a que a cidade enfrentasse, pouco depois (em 411), um golpe oligárquico, que ficou conhecido como governo dos Quatrocentos. Apesar de as fontes indiciarem que havia alguma recetividade a esta experiência oligárquica, o certo é que a restauração democrática ocorreria não muitos meses depois (supra 1.1.2).

Alcibíades viria a regressar alguns anos mais tarde à ribalta política ateniense, criando expetativas que não poderia cumprir, da mesma forma que a cidade já não era capaz de recuperar a influência política e militar de outrora. Ainda assim, em 406 os Atenienses iriam alcançar uma vitória significativa nas Arginusas, que lhes teria permitido terminar o conflito, em termos comparativamente vantajosos, mas os vencedores, chefiados por Cleofonte, não subscreveram os termos da paz e Esparta acabaria por voltar ao ataque. A batalha das Arginusas foi ensombrada por alguns milhares de baixas e pela execução dos generais vencedores, acusados de não terem recolhido os sobreviventes nem, depois, os corpos das vítimas, para lhes serem prestadas honras fúnebres. Terâmenes e Trasibulo, implicados inicialmente no desastre, conseguiram ilibar-se. No entanto, seis generais foram condenados em conjunto, o que constituía um procedimento ilegal, pois tinham direito a ser julgados separadamente. ${ }^{34}$ No ano seguinte, no recontro entre as duas forças, em Egospótamos, Atenas sofre a derrota decisiva. Alcibíades ainda viajou da Trácia, com o intento de alertar os Atenienses para o perigo que corriam e aconselhá-los a irem para um local mais seguro, mas não conseguiu ser escutado. Um comentário feito nas Rãs de Aristófanes é bem elucidativo da desconfiança e dos sentimentos contraditórios que esta carismática figura inspirava: era uma pessoa "por quem [a cidade] ansiava, a quem odiava e a quem desejava possuir". ${ }^{35}$

\footnotetext{
34 Sócrates foi o único dos prítanes a opor-se. Cf. Xenofonte, Hell. 1.6.28-7.35. A condenação destes generais e, curiosamente, mais tarde, a do filósofo ficariam como símbolo dos atos irrefletidos da soberania popular.

35 Ra. 1425.
} 
Na sequência do desastre de Egospótamos, toda a frota foi capturada (à exceção de nove navios com que Cónon escapou) e os prisioneiros executados. ${ }^{36}$ Estava finalmente criada a oportunidade para a discussão do acordo de paz com Esparta, ainda que em condições humilhantes para Atenas. Os termos, negociados por Terâmenes, ${ }^{37}$ previam a demolição das Longas Muralhas e das fortificações do Pireu; a entrega de todos os navios, com exceção de um pequeno número a ser determinado pelo comandante espartano no local; o regresso de todos os exilados; a retirada das cidades ocupadas; a adoção dos mesmos amigos e inimigos que os Lacedemónios. ${ }^{38}$ Abria-se também o caminho para o breve, mas sangrento, governo dos Trinta Tiranos (em 404), que terão possivelmente promovido o assassinato de Alcibíades e foram também responsáveis, em grande parte, pela conotação negativa que, daí em diante, ficou ligada aos termos 'tirania' e 'tirano'.

Ao longo deste período conturbado da história de Atenas, o tema da patrios politeia tornou-se, como atrás se dizia, muito recorrente no debate político e até filosófico, e o seu surgimento é indissociável da crise do regime democrático, especialmente após o desastre da expedição à Sicília, em 413. Embora esta ideologia passadista apareça ligada ao grupo dos moderados ${ }^{39}$ em vários momentos, isso não implica que o conceito seja uma criação sua. O que as fontes sugerem é que seria um tema que circulava nos debates políticos da altura e, se não foram os sofistas a introduzi-lo, é, pelo menos, de aceitar que a sua educação, que formara quase todas as figuras públicas atenienses do último quartel do séc. v, terá contribuído grandemente para alimentar a discussão.

Por outro lado, patrios politeia designava uma realidade pouco precisa, de forma que poderia prestar-se ao uso propagandístico pelas três grandes

36 Cf. Xenofonte, Hell. 2.1.28-32; [Aristóteles], Ath. 34.1-2.

37 Cf. Xenofonte, Hell. 2.2.16-23.

38 A lista aparece completa em Xenofonte (Hell. 2.2.20) e, com algumas variantes, em Lísias (13.14), Andócides (3.11-12 e 39), Diodoro (13.107.4) e Plutarco, Lys. 14.8. Conforme salienta Andrewes (1992), 495-496, alguns dos aliados dos Peloponésios, como Corinto e Tebas, teriam preferido que Atenas fosse simplesmente destruída, mas Esparta negara-se a escravizar uma cidade que tantos serviços concedera à Hélade em momentos de grande aflição. Na decisão dos Lacedemónios devem ter pesado igualmente fatores de estratégia política, como a incógnita sobre quem iria preencher o vácuo de poder na Ática, se Atenas fosse abatida.

39 O seu principal líder foi Terâmenes - figura um tanto lábil do ponto de vista político. Ainda assim, afigura-se seguro sustentar que, ideologicamente, os moderados estariam situados entre os democratas radicais e os partidários da oligarquia. Vide supra 1.1.2. 
tendências políticas da época: os extremistas, os moderados e os radicais. O grande representante dessa constituição ancestral começou por ser Clístenes, mas, num aproveitamento cada vez mais regressivo, passou a Sólon e, na viragem para o séc. Iv, eventualmente a Drácon. ${ }^{40}$ Pesem embora as diferenças de pormenor, as referências a este tópico acabam por ser um claro sintoma de uma mesma realidade: a decadência inelutável de Atenas. Ainda assim, os Atenienses continuavam a dar claramente a preferência ao regime democrático, no qual viveriam durante grande parte do séc. iv, que será um período de pujante vitalidade literária, sendo marcado por figuras importantíssimas da cultura grega, como Platão, Aristóteles e os oradores áticos. Em todo o caso, Atenas não mais recuperaria a hegemonia política e militar que detivera ao longo de boa parte do séc. v. De resto, nem Esparta nem nenhuma das outras póleis gregas conseguiria ocupar de forma duradoira esse posto de referência, abrindo assim caminho à afirmação crescente da Macedónia, primeiro com Filipe II e depois com o filho deste, Alexandre Magno (supra 1.2.1 e infra 6.2, 6.3), cujo notável carisma lhe trará enormes sucessos militares e políticos, além de que marcará o fim do particularismo e vitalidade característicos do sistema da pólis.

O mito da autoctonia e o tema da patrios politeia espelham, assim, de forma elucidativa, dois momentos marcantes da história de Atenas: por um lado, o ponto alto do império ático e a tentativa de legitimar, no plano do mito, o exclusivismo ateniense no acesso às grandes benesses da Simaquia de Delos; por outro, os desmandos da democracia radical, aliada aos efeitos da Guerra do Peloponeso, que arrastariam a cidade para o declínio. Entre ambos os processos, encontra-se uma das maiores figuras de estadistas que a Grécia antiga haveria de ter — Péricles — e que não viveu o suficiente para reconduzir a cidade 'modelo da Grécia' à senda do bom senso e da prosperidade. O teatro, enquanto forma de expressão que vive do pulsar intenso da própria pólis, espelha de maneira particularmente notória estes momentos de tensão histórica e conceptual. É o que se procurará exemplificar no capítulo seguinte, com a análise do Íon de Eurípides (infra 4.3.1), tendo por pano de fundo o cenário histórico e legal analisado nesta secção.

\footnotetext{
40 Este período de indefinição política, compreendido, essencialmente, entre 411 e 404, teve a vantagem prática de estimular o processo de revisão legislativa, que, iniciado em 410, se prolongaria até depois da segunda restauração democrática, em 403.
} 
(Página deixada propositadamente em branco) 


\section{PÓlis, TEATRO E EXERCÍcIO dA CIDAdANIA}

No sistema da pólis, o envolvimento do cidadão individual em tarefas com impacto coletivo alargava-se a todos os domínios de atuação, em matéria religiosa, política, militar, financeira ou mesmo recreativa. A este nível, tem particular destaque o fenómeno teatral, enquanto força viva que espelha intensamente a forma como as esferas do polites e do idiotes se cruzam e interpelam, acompanhando assim de perto as tensões e desafios a que a pólis vai sendo sujeita, confrontando os seus membros, no plano metafórico do passado heróico da tragédia ou na utopia indagadora da comédia, com os grandes problemas do momento. É sobre esse fenómeno que se falará agora, através de uma abordagem de alguns dos aspetos que contribuem para acentuar a dimensão 'política' do teatro, seja no plano material dos bastidores do espetáculo, seja ainda através da análise concreta do fundo legal de uma das tragédias de Eurípides.

\subsection{O teatro grego enquanto 'fenómeno político'}

Embora as origens do teatro grego continuem a suscitar dúvidas e discussões, há um dado que marcará de forma indelével a experiência dramática grega, no que à tragédia e à comédia antiga diz respeito: a sua natureza 'política', isto é, a relação viva e empenhada com a realidade da pólis democrática ateniense, de que constitui simultaneamente reflexo, apologia e ponderação crítica. É portanto legítimo esperar que, embora sem perder de vista a realidade intemporal do universo dramático plasmado em cada peça e válido por si mesmo, as circunstâncias históricas que rodearam a criação e representação do teatro grego, no 
seu contexto original de produção, possam ter tido algum peso na forma como as obras terão sido entendidas pelos espetadores atenienses. Assim poderá ter acontecido, por exemplo, com a Oresteia de Ésquilo e as reformas de Efialtes, que reduziram os poderes do conselho do Areópago, ou então com a Medeia de Eurípides e a lei da cidadania apresentada por Péricles, que vinha limitar o acesso ao estatuto de cidadão. ${ }^{1}$

Ainda assim, se é legítimo falar de um horizonte legal que sirva de referente para o teatro grego, importa não confundir essa manifestação da energia vital da pólis com a mera expressão artística de uma eventual ideologia política. Uma operação dessa natureza estaria exposta a um duplo erro: por um lado, sugerir que o teatro grego estava ao serviço da propaganda ideológica; por outro e em consequência do primeiro, reduzir a mundividência do poderoso fenómeno dramático a um afloramento circunstancial de agendas políticas. Com efeito, nem os traços dessa ideologia propagandística são detetáveis de forma clara (mesmo na comédia antiga, que cultiva, pela própria natureza do género, uma relação mais direta e assumida com a realidade política do momento), nem o teatro grego alcançaria a perenidade e importância que o caracterizam se fosse entendido como simples manifestação artística ao serviço de determinado regime ou governante. A consideração do horizonte legal e político do drama antigo expande os níveis de interpretação do fenómeno teatral, mas não pode ser usada a ponto de adulterar ou manietar a liberdade criativa e crítica dos dramaturgos atenienses. A dimensão política do drama grego deve, pelo contrário, ser entendida como expressão do envolvimento do indivíduo nos interesses e assuntos da coletividade, da pólis, sem ignorar as tensões decorrentes da própria evolução na forma de entender a pertinência desse mesmo envolvimento. É certo que o teatro possui uma dimensão intemporal, ao colocar em cena questões que têm que ver com os próprios dramas da existência humana, que são de todos os povos e de todos os tempos. Há, no entanto, que olhar também para o contexto original de representação, o qual, deixando embora vestígios mais efémeros,

1 Vide análise de Leão (2005b), para o caso da Oresteia, e Leão (2006) para o da Medeia. Para um conjunto de estudos centrados sobre a análise do horizonte legal do teatro grego, vide volume coordenado por Harris, Leão \& Rhodes (2010). Apesar do tempo decorrido desde a sua publicação, Meier (1988) continua a ser de leitura muito proveitosa para a relação entre pólis e tragédia. Vide ainda Fialho (2010a), que analisa os contextos de afirmação ritual da cidadania e da identidade helénica a par da consciência da alteridade, que o teatro também claramente explora. 
não deve ser descurado, por comportar informações que, ponderadas na devida proporção, podem fornecer interessantes chaves interpretativas. Com efeito e à imagem de outras formas de expressão artística, também o teatro possui diferentes públicos e distintos níveis de leitura.

Em termos globais, estes vários elementos contribuem todos, na verdade, para entender a essência do que era colocado em cena: a experiência da vida em democracia. Mostra-o de forma clara a comédia de Aristófanes, por exemplo, não apenas na intensidade com que se atreve a atacar as figuras políticas do momento, como ainda na forma como procura encontrar (no plano da utopia ou no campo da iniciativa privada) soluções para um conflito fratricida e ruinoso, como acontecia com a Guerra do Peloponeso, no último quartel do séc. v. Ilustra-o igualmente a tragédia, como atrás se dizia a propósito da Oresteia e da Medeia, mesmo quando o assunto remete para um passado mítico ou protohistórico, pois o mito tem, precisamente, a vantagem inegável de estimular a reflexão crítica sobre problemas atuais através de um efeito de distanciamento, visível apesar de tudo mais em aspetos acessórios do drama do que no âmago das grandes questões evocadas.

Ainda assim, convém não esquecer que a dimensão cívica do teatro se prendia também com opções muito mais práticas, que tinham de ser tomadas bastante antes de surgir a magia do espetáculo. Iniciava-se com o próprio momento escolhido para as representações — os festivais dionisíacos —, que Atenas soube integrar nas manifestações de religião oficial, retirando, por esta via, a um culto potencialmente perigoso e perturbador da ordem pública, o risco do descontrolo. Por outro lado, os festivais dramáticos eram ainda, em si mesmos, um spectaculum da própria cidade, que o berço da democracia facultava aos milhares de estrangeiros que a visitavam, em particular por altura das Grandes Dionísias. Portanto, não será descabido afirmar que o teatro constituía também uma poderosa arma diplomática e negocial, enquanto prova de desenvolvimento civilizacional e exibição pública do nível de apuramento artístico atingido por Atenas.

Político era, igualmente, o processo de financiamento dos festivais - e é sobre esta dimensão menos conhecida do público apreciador do teatro grego que incidirá a próxima secção (infra 4.2). Com efeito, apesar de os espetadores pagarem bilhete e de o teatro constituir, na época clássica, um verdadeiro fenómeno de massas (comparável aos modernos torneios de futebol), não deixava de ser uma forma de expressão artística cara e deficitária. Ainda assim, não era ao erário 
público que caberia custear o grosso das despesas, mas antes aos cidadãos privados mais ricos, através de um serviço cívico que o estado lhes impunha: a liturgia. É certo que este ministério poderia reverter a favor da projeção do seu patrocinador involuntário, enquanto figura pública, sobretudo se a pessoa em questão alimentasse ambições políticas, mas não deixava, ainda assim, de ser um encargo pesado, que nem todos cumpririam de bom grado. Mesmo assim, espelhava igualmente a estreita união entre o exercício ativo da cidadania e a mimesis dramática.

\subsection{O processo de financiamento dos festivais de teatro}

A maneira como se preparava e financiava o festival dramático constitui, com efeito, uma expressão notável do espírito próprio do sistema de pólis, pois a maioria dos encargos era suportada não pelo estado, mas pelos cidadãos com mais posses. ${ }^{2}$ Era, além disso, um dos fatores que determinavam de forma clara a qualidade final do espetáculo. ${ }^{3}$ A obrigação de suportar as despesas ligadas aos festivais dramáticos era designada por coregia (choregia) e correspondia a uma variante dos diferentes tipos de serviços públicos prestados por privados como pagar a equipagem de um navio durante um ano (trierarquia), ou o treino de uma equipa de atletas para uma prova (gimnasiarquia). Essas tarefas designavam-se globalmente por liturgias, ou seja um tipo de impostos especiais que o sistema democrático impunha aos cidadãos mais abastados. ${ }^{4}$ Regra geral, a coregia era evitada pela classe litúrgica, por ser um pesado encargo, mas, quando

2 E por vezes também pelos metecos, que poderiam custear as despesas de montagem do espetáculo, mas somente nas Leneias, um festival mais caseiro. Ou seja, mesmo para prestar um serviço ao estado e à população, havia uma diferenciação clara entre o estatuto de cidadão de plenos direitos e o de um estrangeiro com mera autorização de residência. Cf. escólio a Aristófanes, Pluto, 954. Sobre as principais características dos festivais dionisíacos celebrados em Atenas (Antestérias, Leneias, Dionísias Rurais e Dionísias Urbanas ou Grandes Dionísias), vide Rocha Pereira (2006) 354-368.

3 Vide Csapo \& Slater (1998), 139-157, que fornecem um enquadramento muito útil sobre o problema, acompanhado dos testemunhos antigos mais pertinentes para a questão. Vide ainda Oliveira (1991) 5-20. O trabalho de Isabel Castiajo, O teatro grego em contexto de representação, cuja publicação é esperada para 2012, constituirá o estudo mais completo sobre esta matéria, escrito até agora em língua portuguesa.

4 A pertença à classe litúrgica obedecia a qualificações de propriedade, acessíveis apenas a uma percentagem muito reduzida da população, pois mesmo a liturgia mais baixa obrigava a posses de referência superiores ao que um trabalhador especializado poderia esperar ganhar durante toda a vida. Para mais pormenores, vide Csapo \& Slater (1998) 139. 
a designação para essa função se tornava uma inevitabilidade, poderia ser usada como rampa de lançamento para a promoção da imagem pessoal (especialmente por quem alimentasse ambições políticas), sendo uma oportunidade para dar mostras de empenho e zelo públicos, que, levadas ao excesso, poderiam acarretar a própria ruína financeira do seu promotor. Em casos excecionais, um cidadão poderia ser honrado com a isenção do pagamento de impostos (ateleia), ficando por conseguinte liberto da obrigação de assegurar liturgias, com exceção da trierarquia, certamente por causa da relação que esta última estabelecia com a necessidade de assegurar a defesa da pátria em situações de urgência.5 Em desespero de causa, o cidadão encarregado poderia recorrer a um processo da antidosis ('troca de propriedade'), apresentando ao arconte que o designara um candidato que julgava mais qualificado que ele próprio: o visado poderia então assumir a despesa ou aceitar o processo de permuta de posses, opção que obrigaria o choregos inicial a assumir os custos decorrentes da liturgia. ${ }^{6}$

A Constituição dos Atenienses, um tratado da segunda metade do séc. IV atribuído a Aristóteles, embora essa autoria seja disputada, é uma das fontes que abordam esta problemática, ao analisar as funções do arconte-epónimo (que dava nome ao ano, permitindo assim estabelecer uma tábua cronológica). Vale a pena recordar o passo em que o autor refere a questão das obrigações litúrgicas (Ath. 56.3):

Em seguida, designa como coregos para os poetas trágicos três cidadãos entre todos os Atenienses mais ricos; outrora, instituía também cinco para os poetas cómicos, mas agora são as tribos que tratam dessa indigitação. Depois, recebe os coregos apresentados pelas tribos: para os coros de homens e de rapazes 7 e para os coros cómicos das Dionísias, bem como para os coros de homens e de rapazes

\footnotetext{
5 Havia ainda outras regras a ter em conta no momento de designar um choregos, como evitar que alguém tivesse mais do que uma liturgia ao mesmo tempo, ou que repetisse exatamente a mesma ou ainda que tivesse de exercer várias em sucessão próxima; os cidadãos que tivessem menos de quarenta anos também não podiam ser choregoi de ditirambos que envolvessem rapazes. Em todo o caso, é possível que algumas destas normas talvez não fossem aplicadas ainda no séc. v.

6 Em todo o caso, seria um recurso certamente usado apenas em última instância. Para mais pormenores sobre a antidosis, vide Harrison (1968-1971) II. 236-238; MacDowell (1978) 162-164.

7 Nos concursos de ditirambos.
} 
das Targélias. ${ }^{8}$ Nas Dionísias, há um coro por cada tribo; nas Targélias há um coro por cada duas tribos e cada uma delas fornece o corego, à vez. Por solicitação dos coregos, o arconte dá seguimento aos processos de troca de propriedade e apresenta os pedidos de isenção: por exemplo, se alguém sustenta que já desempenhou antes a mesma liturgia ou então que deveria estar isento por haver assumido outra liturgia, cujo período de isenção ainda não expirou, ou que ainda não atingiu a idade; de facto, o corego de um coro de rapazes deve ter mais de quarenta anos. Pesigna também os coregos para o festival de Delos e um chefe da embaixada para o barco de trinta remadores que transporta os jovens.

Este passo esclarece que a escolha dos choregoi era feita pelo arconte-epónimo, informando ainda que, entretanto (talvez em meados do séc. Iv), parte dessa responsabilidade fora transferida para as organizações tribais. ${ }^{10}$ A primeira função de um corego consistia em equipar e treinar o coro trágico, cómico ou de ditirambos, ficando responsável pela seleção dos membros do coro, que, em princípio, deveria ser formado por outros cidadãos atenienses, membros da mesma tribo. Além disso, tinha de fornecer um local para ensaios do coro e de sustentar o poeta e o flautista e ainda o diretor do coro (chorodidaskalos), no caso de o coro não ser preparado pelo poeta em pessoa. Eram encargo seu igualmente todos os adereços e acessórios usados na produção, incluindo os atores extra. O choregos vencedor do ditirambo ganhava uma trípode que dedicava a Diónisos, erigindo para isso, e também a expensas suas, um monumento votivo chamado precisamente de corégico. ${ }^{11} \mathrm{O}$ vencedor da tragédia ganhava um bode que sacrificava a Diónisos ${ }^{12}$ e o da comédia um saco cheio de figos e um odre de vinho. ${ }^{13}$

\footnotetext{
8 Festival em honra de Apolo, celebrado em maio, onde havia concursos musicais entre coros, mas não espetáculos de teatro. Cf. Fritz \& Kapp (1974) 132.

9 Fazia-se a mesma exigência para os precetores de efebos (cf. Ath. 42.2).

10 Vide Csapo \& Slater (1998) 143.

11 Em Atenas, é ainda hoje visível o monumento corégico de Lisícrates (c. 334), mas teria existido uma verdadeira rua das trípodes.

12 Notar que a palavra tragédia (tragoidia), que significa à letra 'canto do bode', derivará, ao que se pensa, do preço de um bode, pelo qual os primeiros coros trágicos competiam. Vide Wiles (2000) 34 .

13 Os choregoi dramáticos raramente faziam monumentos votivos (ao contrário dos choregoi de ditirambos), preferindo optar por dedicar uma máscara ou pinturas alusivas à representação.
} 
Os encargos eram muito elevados, embora pudessem variar, já que as Leneias, por exemplo, saíam mais baratas que as Grandes Dionísias. O espetáculo mais caro de montar era o ditirambo (embora fosse o que durava menos tempo), por causa do elevado número de bailarinos e também devido à acentuada competição entre as tribos concorrentes. Seguia-se, em termos de grandeza de encargos, a tragédia (dado o número de peças) e finalmente a comédia. ${ }^{14}$ Os gastos de um só festival eram equivalentes aos de um décimo de toda a frota durante um ano, mesmo em tempo de guerra. Parece assim justificado o comentário de Plutarco, ${ }^{15}$ ao sustentar que Atenas teria gasto mais dinheiro a representar os dramas de figuras como Édipo, Medeia e Electra do que a defender o império e a combater os Persas.

Embora as leitourgiai se prestassem a ser usadas para granjear popularidade em termos políticos e até para fazer demonstração pública de efetivo empenho cívico, da parte de algum cidadão acusado em tribunal, há razões para crer que os custos não pareciam ser recompensados pelos benefícios, pelo que, regra geral, os ricos preferiam ser aliviados desses encargos, procurando ganhar o direito à isenção (ateleia) de suportar esse tributo. Mas mesmo sem esse recurso extremo, uma outra forma de diminuir os encargos era através da synchoregia, ou 'partilha da choregia' por duas ou mais pessoas, se bem que as fontes relativas à forma como se processava esta possibilidade sejam bastante contraditórias. ${ }^{16}$ O sistema da choregia foi abolido no último quartel do séc. Iv, durante o governo oligárquico de Demétrio de Fáleron, que substituiu os choregoi característicos da democracia por um magistrado eleito anualmente, designado pelo termo agonothetes. A ele cabia a organização de festivais dramáticos e de outro tipo,

14 Para os ditirambos escolhiam-se dois coregos, por cada uma das dez tribos da cidade, na medida em que, por cada tribo, participava um coro de homens e outro de rapazes. Só nesta parte do festival, estariam envolvidos mil participantes, sem contar com os músicos e treinadores, pois cada coro de ditirambos comportava cinquenta elementos. Um coro de tragédia tinha doze coreutas no tempo de Ésquilo e quinze depois de Sófocles, mas cada autor apresentava-se a concurso com uma tetralogia (três tragédias e um drama satírico). A comédia implicava um coro de vinte e quatro membros, se bem que a caracterização e adereços exigissem mais esforço do que a montagem de uma tragédia individual. Para uma estimativa global dos custos envolvidos, vide Csapo \& Slater (1998) 140-141.

15 Sobre a glória de Atenas, 348d-349b.

16 Um escólio a Aristófanes, Rãs, 405, cita a autoridade de Aristóteles, para sustentar que, nas Grandes Dionísias de 410 ou de 406, já se tinha recorrido à synchoregia, facultando assim o único testemunho seguro da existência deste sistema de partilha de encargos nas Dionísias Urbanas. Sobre as dificuldades que envolvem a interpretação deste testemunho, vide Csapo \& Slater (1998) $142-143$ e $155-156$. 
para cuja realização contribuiria também com fundos próprios. A avaliar pelas inscrições existentes, o fim do sistema da choregia e a sua substituição pelo da agonothesia deve ter ocorrido entre 318-307. Antes disso, por volta do ano 330, Aristóteles sustentara já, na Política (1321a31-42), que a transformação da choregia numa magistratura seria uma das formas de a oligarquia poder manter o poder dentro da cidade. Ora sendo Demétrio um filósofo peripatético, não é improvável que estivesse a aplicar a receita sugerida pelo mestre. De resto, a comprovar a eficácia popular deste novo modelo está o facto de a agonothesia ter sobrevivido aos conflitos sociais e políticos que marcaram os séculos seguintes, mantendo-se portanto como o modelo de referência para a organização dos festivais dramáticos.

Igualmente bem sucedidas continuariam a ser a atividade teatral e a profissão de ator. Partindo de um modelo artístico e cívico, em que todas as forças vivas da pólis se concentravam a promover uma das mais impressionantes manifestações culturais da Grécia antiga, o fenómeno dramático conseguiria sobreviver à decadência do modelo democrático que fora o motor da sua grandeza, seja através da evolução do género, que se desloca das grandes questões da comunidade para os interesses mais privados (como a comédia nova claramente ilustra), espelhando assim o avanço do idiotes sobre o polites, seja ainda acompanhando a evolução do gosto do público, que passaria a favorecer a reposição dos grandes autores do passado, representados agora pelos grandes atores do presente.

\subsection{Horizonte cívico e horizonte dramático}

Na abordagem feita numa das secções anteriores (3.1), discutiu-se, com algum pormenor, a problemática da relação entre o tema da autoctonia e a noção de cidadania, bem como a incidência desses conceitos sobre o entendimento da enktesis - o direito à posse da terra e dos bens imóveis que sobre o solo assentam os seus fundamentos, i.e. as casas (3.2). Na sequência do que também se afirmou já sobre a natureza 'política' do teatro (4.1), vai-se agora procurar exemplificar a forma como o referente legal de um polites poderia influenciar a sua maneira de viver criticamente a experiência dramática enquanto theates ('espetador'). Embora com um grau variável de pertinência, 
este exercício hermenêutico pode ser desenvolvido tanto com as comédias de Aristófanes como com qualquer uma das obras de Ésquilo, Sófocles ou Eurípides. Ao decidir optar por um exemplo retirado deste último, escolheu-se seguir também o caminho mais difícil, ou seja, explorar a pertinência deste mesmo juízo num autor que anuncia já, de forma insistente, a emergência de uma sensibilidade cívica diferente. Mas a consciência desta eventual limitação não bastará para pôr em causa o facto de o público de Eurípides corresponder, em grande parte, ao mesmo grupo de pessoas que se sentava na assembleia ou nos tribunais populares atenienses, partilhando por conseguinte a referência a um mesmo horizonte legal que marcava a forma como os problemas colocados em cena eram apreendidos pelo auditório que assistia às representações teatrais. É essa realidade que se pretende demonstrar na próxima secção.

\subsubsection{O Íon de Eurípides}

O leque de argumentos evocados anteriormente a propósito dos conceitos de autochthon e de enktesis (supra 3.1 e 3.2) encontra-se, na verdade, claramente ativo no Íon de Eurípides, uma tragédia que explora de maneira muito crítica as incoerências do mito da autoctonia, precisamente pelos níveis de exclusão que pode promover, projetando essas mesmas incoerências até ao nível do paradoxo. A abordagem que agora se propõe visa analisar a forma como o horizonte jurídico decorrente daqueles princípios pode estimular uma leitura reveladora de interessantes conexões entre o referente legal e a interpretação da obra literária. ${ }^{17}$

Que o problema da autoctonia assume uma posição central neste drama euripidiano é uma realidade patente logo desde o prólogo enunciado por Hermes. Com efeito, no resumo que faz das circunstâncias que acompanharam a geração e nascimento irregulares de Íon, o deus avança desde logo o tema da autoctonia, seja implicitamente, ao referir a ascendência de Creúsa, apresentada como 'filha de Erecteu' (v. 10), seja através da identificação expressa de Erictónio como 'nascido da terra' (vv. 20-21). Conforme se viu previamente, a conexão

\footnotetext{
17 Os argumentos agora aduzidos recuperam, no essencial, a exposição apresentada em Leão (2011a).
} 
entre a história primitiva de Atenas e as figuras de Erecteu e Erictónio remonta a tempos bastante recuados, sendo, por conseguinte, anterior ao desenvolvimento do mito da autoctonia, mas no tempo de Eurípides as duas tradições já se haviam fundido, no sentido de expandir a leitura do termo autochthon, ao favorecer a ideia de uma relação nutriz entre a terra e os Atenienses. ${ }^{18}$ De resto, uns versos adiante, Hermes salienta isso mesmo de forma clara, ao reproduzir as instruções que recebera de Apolo, quando do nascimento de Íon: "dirige-te ao povo autóctone da ilustre Atenas" (vv. 29-30).

Esta insistência na autoctonia de Creúsa e dos Atenienses irá tornar ainda mais evidente o contraste estabelecido com Xuto, cujo casamento com a jovem amante de Apolo é apresentado como uma ligação desigual, mesmo tendo sido motivada por uma conjuntura extraordinária. A forma como Hermes apresenta a questão sintetiza, de maneira bastante eficaz, a essência jurídica da conveniente solução encontrada por Apolo para a melindrosa situação política e social do oikos de Creúsa (vv. 57-73):

Por seu lado Creúsa, mãe do jovem, casou (gamein) com Xuto nas seguintes circunstâncias: surgiu, entre Atenas e os Calcodôntidas - a quem pertence a terra de Eubeia - , uma onda de guerra. Ao dar o seu melhor por Atenas, Xuto saiu vitorioso e recebeu a honra de casar (gamein) com Creúsa. Apesar de ser estrangeiro, era aqueu, filho de Éolo, rebento de Zeus. Mas o longo casamento é estéril (ateknos) e vêm ambos para este oráculo de Apolo, devido ao desejo de descendência. É Lóxias que conduz o destino (tyche) a este ponto; não está tão desatento como parece. Pois o deus dará a Xuto, quando ele entrar neste templo, o seu próprio filho: dirá que nasceu dele, de modo a que, entrando em casa da mãe, o filho seja reconhecido por Creúsa, o casamento (gamos) com Lóxias permaneça secreto e o rapaz fique com o que lhe é devido.

18 No caso concreto de Íon, o mito de Erictónio apresentava ainda vantagens acrescidas, porquanto existiam evidentes semelhantes entre a maneira como ambos haviam sido concebidos. Conforme sintetiza Lourenço (1994), 40 n. 5, "A afinidade de circunstâncias entre Erictónio e Íon é um motivo importante ao longo da peça: tal como o herói nascido da Terra, Íon foi concebido na sequência de uma violação; foi exposto numa gruta, símbolo ctónico por excelência, guardado por serpentes. Note-se, ainda, que Erictónio foi dado por Atena a Cécrops porque este não tinha filhos, tal como Apolo haverá de dar Íon a Xuto pela mesma razão.” As traduções do Íon serão sempre feitas a partir da versão portuguesa de F. Lourenço. 
Este passo comporta algumas particularidades dignas de nota. Em primeiro lugar e embora esse aspeto seja secundário para os objetivos deste estudo, importa referir a ambiguidade resultante do uso do termo gamos (e seus derivados) para designar a associação de Creúsa com Xuto e com Apolo. No primeiro caso, o termo implica uma alusão à celebração do matrimónio, mas no segundo qualifica simplesmente uma relação de natureza sexual. Ao escolher um termo da mesma família vocabular para descrever, em contextos muito próximos, duas diferentes situações, Eurípides contribui para acentuar a natureza ambivalente da relação de Creúsa e Apolo, tal como vem caracterizada ao longo da peça. ${ }^{19}$ Outro elemento importante para o desenvolvimento da ação assenta no facto de Xuto ser considerado estrangeiro, aspeto que, apesar da sua ilustre ascendência divina, perturba claramente o seu posicionamento na estrutura do governo de Atenas. Acresce a essa limitação a circunstância de o casamento ser 'sem filhos' (ateknos), o que colocava obviamente em risco a continuidade do oikos. ${ }^{20}$ É por este conjunto de razões que a solução preparada por Apolo é uma mentira tão obsessivamente conveniente: ao fazer crer a Xuto que Íon é filho dele e ao permitir a Creúsa encontrar e aceitar o filho, o deus salva todas as aparências de uma ética social e religiosa confortavelmente instalada, não apenas porque mantém em segredo o seu ato de abuso, como garante a continuidade do oikos em termos socialmente aceitáveis, além de salvaguardar igualmente a superioridade da autoctonia no acesso ao governo de Atenas.

Dentro desta cadeia retorcida de conveniências múltiplas articulam-se ainda, na perfeição, dois princípios reguladores à primeira vista contrários e inconciliáveis: a evolução errática dos acontecimentos (assinalada pela referência à tyche) e o aparente desinteresse de Apolo na sorte de Creúsa e de Íon, quando na realidade tudo obedeceria a um desígnio premeditado pelo deus. Ou seja, as palavras iniciais de Hermes apresentam não apenas os antecedentes da ação, como a essência do horizonte legal que lhe serve de referência, além de adiantar,

19 Este pormenor é importante para compreender também o tipo de linguagem usada para descrever o tópico da violação. Devo esta informação a A. Scafuro, que habilmente identifica o que ela chama de "code of 'female' shame-directed discourse" na forma como Creúsa e outras heroínas trágicas falam acerca da experiência da violação. Vide Scafuro (1990), sobretudo 138-149, para o caso de Creúsa no Íon de Eurípides.

20 De resto, as reflexões feitas pelo Coro durante o primeiro estásimo procuram, em boa parte, sublinhar a relevância de ter descendência (vv. 472-491), sendo atribuída particular importância ao papel dos filhos na transmissão do património e na defesa da pátria. 
desde logo, a oportuna solução encontrada. Será esta tessitura de intenções que as partes do drama irão confirmar repetidamente, como se poderá constatar através da evocação de alguns dos momentos mais significativos da argumentação usada pelas personagens.

Na sua primeira aparição em cena, Íon mostra ter assumido a expetável posição social de quem havia sido uma criança exposta e, portanto, sem filiação identificada (vv. 109-111): "Pois tendo crescido sem pai nem mãe, sirvo o templo de Febo que me criou." Ainda assim, o jovem sente uma ligação especial a Apolo e por isso dirige-se a ele, com profunda ironia dramática, na qualidade de "pai que me deu o ser" (v. 136). A razão para esse afeto filial em relação ao deus tem que ver não com a consciência de que poderia ser filho dele — facto que obviamente ignora - , mas com a gratidão decorrente de ter encontrado alimento e proteção junto do seu templo. Com efeito, é essa a lógica retributiva que se espera da ética das relações entre senhor e servo, como o próprio Íon reconhece e à qual aderiu de bom grado: servir (vv. 182-183) quem lhe fornece alimento e proteção (vv. 137-139). ${ }^{21}$ Este princípio retributivo também se aplica à relação de sustento mútuo que vincula pais e filhos legítimos, mas numa lógica completamente distinta: com efeito, à paidoboskia/paidotrophia o filho legítimo deve responder, mais tarde, com a geroboskia/gerotrophia. Estes dois pares de princípios são, no entanto, diretamente proporcionais, porque se observam entre pessoas com o mesmo estatuto social; as obrigações cultivadas entre servo e senhor assentam, pelo contrário, na consciência da desigualdade estatutária. ${ }^{22}$

O diálogo inicial entre Íon e Creúsa recupera, de novo, todo o imaginário ligado a Erictónio, a Erecteu e à autoctonia, ${ }^{23}$ que serve de pano de fundo para retomar a ideia, sugerida já no prólogo por Hermes, de que o casamento entre Creúsa e Xuto constitui uma ligação desigual, em termos que vale a pena recordar na íntegra (vv. 289-293):

\footnotetext{
21 Mais adiante, no diálogo com Creúsa (vv. 309-311), Íon afirma-se como escravo (doulos) de Apolo, mas desconhece as circunstâncias que o conduziram a essa situação.

22 Questão abordada mais amplamente em Leão (2011b).

23 Vv. 266-270. O v. 267 é particularmente expressivo, referindo-se a Erictónio: "Foi da terra que nasceu o teu antepassado, pai de teu pai?".
} 
Íon: Mas quem dentre os Atenienses, senhora, é que te desposou?

Creúsa: Não foi um cidadão (astos) ateniense, foi um estrangeiro.

Íon: Quem? Alguém que tenha nascido nobre, forçosamente...

Creúsa: Foi Xuto, nascido de Éolo, filho de Zeus.

Íon: E como, sendo estrangeiro (xenos), é que te obteve a ti, que és de Atenas?

Este passo é particularmente interessante, para entender a forma como o tema da autoctonia vai sendo amplificado ao longo do drama. À pergunta de Íon, que esperaria que Creúsa tivesse casado com um ateniense, ela responde significativamente que não casou com um 'cidadão' (astos), mas antes com um 'estrangeiro', conceito que no original vem referido através de uma longa perífrase, onde avulta a noção de 'terra': à letra 'alguém importado de uma outra terra'. ${ }^{24}$ Íon insiste em que esse estrangeiro deverá ser por certo alguém de nascimento nobre, mas nem a ascendência divina de Xuto impede que o jovem se espante com o facto de um estrangeiro (xenos) ter desposado uma pessoa nativa. Creúsa explicará mais adiante que o seu casamento com Xuto decorreu de um dote de guerra, pela forma como o atual marido havia defendido Atenas. ${ }^{25}$ O que surpreende nesta situação não é tanto a realização de um casamento nestas circunstâncias, mas antes o facto de Xuto ter ficado a viver em Atenas. ${ }^{26}$ Com efeito, os casamentos mistos eram relativamente frequentes em Atenas, ao menos até à lei da cidadania de Péricles (supra 3.), mas geralmente era a mulher que se deslocava para o oikos do marido e não o contrário. É esta conjuntura, aliada à autoctonia de Creúsa, que debilita a posição de Xuto, enquanto estrangeiro, numa cidade como Atenas, mesmo sendo descendente de Zeus e tendo praticado proezas suficientemente marcantes para lhe permitirem merecer aqueles esponsais.

Estas contingências voltam a estar presentes quando Xuto revela a Íon que o jovem é seu filho, num diálogo permeado pelo humor equívoco e pela ambiguidade, não só na forma como Xuto aborda Íon (que, num primeiro momento,

24 Embora correta em termos de apreensão do sentido global, a tradução de F. Lourenço acaba por simplificar talvez em demasia as implicações do texto original.

25 Já Hermes se tinha referido a esse pormenor (vv. 58-64).

26 O casamento de Édipo com a rainha de Tebas, viúva de Laio (e sua mãe), como recompensa por haver livrado a cidade da Esfinge, tem de comum com a posição de Xuto o facto de ambos terem recebido uma recompensa excecional, na sequência de um serviço particularmente importante prestado à cidade que os acolheu. 
julga estar a ser assediado ${ }^{27}$ ), como ainda pela maneira como responde à questão de Íon ser tanto seu filho como oferta de Apolo (v. 537). A ambiguidade continua ainda no facto de Xuto se ter esquecido de perguntar ao deus quem era a mãe da criança, pormenor que motivou a ambos um subtil comentário (v. 542):

Íon: Nasci com a terra como mãe.

Xuto: A terra não dá à luz crianças.

A ironia do passo é dupla, pois ambos os interlocutores parecem desautorizar o mito de autoctonia: ${ }^{28}$ Xuto de forma directa e Íon ao sugerir uma hipótese que não passa de um comentário sardónico, que o leva, aliás, logo adiante, a aventar a possibilidade de Xuto ter tido um 'leito ilegítimo' (v. 545: nothon lektron) que estaria na origem do seu nascimento. Em resultado desta revelação, o jovem livra-se da condição de escravo (v. 556), mas nem a reputada ascendência divina de Xuto, que se estenderia também a Íon (v. 559), chegaria para o livrar do estigma de ser um filho ilegítimo (nothos), precisamente o termo por ele usado alguns versos antes para qualificar os supostos devaneios eróticos de Xuto. Com efeito, à luz da prática usual do direito ático, um filho de uma relação clandestina poderia ver reconhecida a paternidade e assim garantir o estatuto de pessoa livre, mas continuava a ser considerado nothos, sendo penalizado em termos de prerrogativas legais. ${ }^{29}$ Embora o argumento do drama euripidiano decorra no passado mítico da cidade, ainda assim é muito claro que o comentário que Íon tece, ainda no segundo episódio, pressupõe uma audiência familiarizada com as expetativas legais de um cidadão de finais do séc. v (vv. 585-594):

O aspeto das situações, vistas de perto e de longe, não parece ser o mesmo. Bendigo o que sobreveio, pois encontrei em ti um pai. Mas ouve, pai, as coisas

\footnotetext{
27 Já Wilamowitz (1926), 111, reconhecia que esta cena tinha a aparência de "ein erotischer Überfall".

28 Neste sentido se pronunciava já Conacher (1967), 284 n. 53, ao ver nas palavras de Xuto uma ridicularização daquele mito ateniense.

29 Para mais pormenores, vide Leão (2005c) 21-22 e 28.
} 
de que estou a tomar consciência. Dizem que o povo da gloriosa e autóctone Atenas é uma raça livre de sangue estrangeiro - e é lá que eu, detentor de duas desgraças, vou cair: filho de pai estrangeiro e eu próprio de nascimento ilegítimo (nothagenes). E com este estigma vergonhoso ficarei sem jeito e, não sendo ninguém, não serei chamado por nenhum nome.

Este passo sintetiza, de forma notável, as tensões sociais que talvez andassem na ordem do dia, se de facto o Íon foi composto à volta de 413/12, portanto na altura do desastre da expedição à Sicília, evento que representaria um sério revés para a democracia ateniense e prepararia o campo para a revolta oligárquica que se seguiria pouco depois. ${ }^{30}$ Por outras palavras, as reflexões de Íon espelham as consequências nefastas do mito da autoctonia quando conjugado com a lei de Péricles relativa à cidadania: apesar de ser livre e de a sua paternidade ser reconhecida por Xuto (o qual por sua vez descende de Zeus e é casado com uma ilustre cidadã autóctone), Íon sente que, aos olhos dos restantes atenienses, nunca passará do estatuto de nothos o que lhe tolherá qualquer veleidade de ser plenamente aceite pelos verdadeiros autóctones. ${ }^{31}$

Xuto apercebe-se dos riscos e, por isso e para não ferir a sensibilidade da esposa, que julgava estéril, decide-se a levar Íon na qualidade de 'visitante' e não como filho (v. 656), até que o tempo oportuno (kairos) lhe permitisse convencer Creúsa a aceitar que ele ficasse 'com o cetro daquela terra' (v. 660). Embora não abertamente declarada, a estratégia de Xuto parece passar por levar Íon como convidado seu de visita à cidade, ensaiando talvez com o tempo uma integração paulatina, que poderia passar por fazer de Íon um meteco ou um filho adotivo, conseguir que fosse elevado a cidadão pela pólis ateniense e, por último, abrir-lhe o caminho do trono. Embora este plano de atuação seja meramente especulativo, o certo é que o fim último será de facto atingido: Íon acabará por ser integrado, repondo a

\footnotetext{
30 O golpe oligárquico de 411, que daria origem ao efémero governo dos Quatrocentos (supra 1.1.3). Sobre esta questão, vide Ferreira \& Leão (2010) 229-231. Sobre a datação do Íon, vide Lourenço (1994) 14-15.

31 É por si mesma evidente a semelhança deste raciocínio com as implicações do passo do Epitaphios (60.4) atribuído a Demóstenes e anteriormente objeto de análise (supra 3.1). Não falta, sequer, a relação clara entre a autoctonia, o direito à posse da terra (enktesis) e ao seu governo. Cf. vv. 1295-1303, em especial a afirmação de Creúsa (v. 1299): "Um aliado estrangeiro não deveria possuir terra".
} 
esperança de manutenção do oikos de Xuto e de Creúsa e ocupando o governo de Atenas. Porém, como a deusa Atena explicará na intervenção ex machina final, isso fica a dever-se, em última análise, à efectiva autoctonia de Íon e não à putativa paternidade de Xuto (vv. 1571-1572):

Creúsa, dirige-te com o teu filho ao país de Cécrops e senta-o no trono real! É que, descendendo de Erecteu, é justo que ele reine sobre a minha terra.

O tema da autoctonia é, assim, explorado por Eurípides até ao paroxismo mais surpreendente: embora Xuto tenha uma ascendência notável, que entronca no próprio Zeus, o seu contributo para a resolução do problema é meramente instrumental. O dramaturgo chega ao ponto de sustentar, pela boca de Creúsa (vv. 1539-1545), que, se tivesse sido declarado filho de Apolo, Íon não passaria de um bastardo, sem direito à herança nem ao nome do pai. Estão, por isso, revestidas de intensa ironia as palavras finais de Atena, ao expor as vantagens de um plano divino (tacitamente assumido pelos humanos), cujo único objetivo é salvaguardar uma solução socialmente eficaz porque permite manter um engano para todos conveniente. A autoctonia falou mais forte nos bastidores da ação, mas na aparência respeitaram-se as regras de convívio social, cujo carácter absurdo é reforçado pela embrulhada jurídica a que deram origem: contrariamente à prática legal dominante, foi a linhagem feminina que saiu afinal privilegiada, embora formalmente a linhagem masculina tenha sido também acautelada, pois um antigo filho nothos (de Apolo, mas não de Xuto), reconhecido pelo pretenso pai, virá a herdar o trono de Erecteu, sendo esse pai na verdade um estrangeiro que, por isso mesmo, não poderia passar a um falso filho o trono da Ática, pólis por excelência de cidadãos autóctones. Rebuscado, sem dúvida, mas será nessa mesma argumentação tortuosa que residirá a falácia democrática do mito da autoctonia, tão habilmente exposta pelo dramaturgo.

E para formalizar este logro conivente que a todos tranquilizou, nada melhor do que a superior declaração de Atena, que dá também o mote certo para se encerrar esta análise da tragédia euripidiana (vv. 1595-1603):

Apolo resolveu tudo da melhor maneira. Primeiro, deu-te um parto sem sofrimento de modo a que os teus familiares não se apercebessem de nada. Depois 
de teres dado à luz este rapaz e de o teres envolvido em faixas, manda a Hermes que o agarre nos seus braços e o traga para cá; alimentou-o e não deixou que ele morresse. Agora tens de calar o facto de a criança ter nascido de ti, para que a ilusão possa apoderar-se de Xuto de modo aprazível e para que tu, mulher, te vás embora com o bem que é teu.

O passo encontra-se embebido por completo em fina ironia euripidiana, que constitui de resto um dos elementos que tão notavelmente caracterizam a sua produção dramática. Contudo, a constatação desse facto não prejudica, mas antes ajuda a reforçar, as bases da argumentação que se procurou demonstrar: o referente legal constitui um instrumento hermenêutico legítimo e revelador da profunda natureza 'política' do teatro clássico. Esse elemento distintivo explica-se, de novo, pela intensa vivência cívica deste período da história da Grécia, pois o mesmo horizonte pairaria nas expetativas de uma audiência cuja composição seria em boa parte a mesma, quer quando se reunia para participar nas instituições da pólis democrática (como polites), quer quando o fazia para assistir (como theates) a uma das mais notáveis criações do espírito artístico helénico. 
(Página deixada propositadamente em branco) 


\section{POLITES, IDIOTES, KOSMOPOLITES A ATENAS DE FÓCION}

\subsection{Polites e idiotes}

Conforme se comentava no capítulo inicial de enquadramento (supra 1.1), o exercício empenhado e consciente da cidadania exigia de cada polites um envolvimento direto nos interesses da cidade, desígnio que representava um privilégio em relação a todos quantos se encontravam excluídos, em maior ou menor grau, do uso pleno daquele estatuto, mas que constituía também uma obrigação, à qual alguns poderiam sentir a tentação de fugir, para evitar, por exemplo, o risco de participar em campanhas militares ou de colocar meios próprios ao serviço de iniciativas comuns (supra 4.2). Esta natural expetativa de envolvimento nas atividades da pólis está patente, de resto, na própria cunhagem do termo mais usual para designar o estatuto de 'cidadão' — polites —, precisamente pela estreita ligação que pressupõe com o conceito de cidade-estado. Tal facto não implica, necessariamente, que um cidadão não pudesse acompanhar de perto os seus interesses privados (ta idia), pois esse era também um direito que lhe assistia. De resto as fontes mostram, com alguma frequência, que a noção de polites e a de idiotes (enquanto 'cidadão privado') podem conviver de forma relativamente pacífica e até ser mesmo tomadas como quase sinónimas, na altura de designar o cidadão comum, enquanto ‘átomo' central do corpo cívico, cuja agregação num grupo mais vasto dá origem à coletividade (to koinon, to demosion) ou simplesmente pólis. ${ }^{1}$

\footnotetext{
1 A expressão 'átomo do corpo cívico' é inspirada na definição de Rubinstein (1998) 127. Mais adiante (142), nesse mesmo estudo, pode encontrar-se um elenco das fontes que exploram a contraposição entre idiotes e pólis ou coletividade, se bem que não forçosamente de forma negativa.
} 
Com efeito, o florescimento da cidade-estado, sendo um bem para toda a comunidade, é também uma situação que traz benefícios diretos a cada um dos seus cidadãos privados ou idiotai. É isso mesmo que Péricles procura sublinhar numa das suas intervenções, tal como aparece registada em Tucídides (2.60.2-3):

Com efeito, eu acho que uma pólis que funcione bem como um todo traz mais vantagens aos particulares (idiotai), do que quando floresce com a sorte de cada um dos cidadãos (politai), mas falha no seu conjunto. Na verdade, se um homem goza de boa situação, no que lhe diz respeito, ainda assim nada o protege da destruição, se a pátria (patris) entrar em ruína; pelo contrário, se cai em desgraça numa cidade que é próspera, pode salvar-se com maior facilidade. [tradução minha]

As considerações de Péricles, feitas num momento em que os Atenienses punham em causa os primeiros resultados da estratégia seguida na fase inicial da Guerra do Peloponeso, diluem, de maneira muito clara, o risco de confronto entre interesses públicos e privados. Na realidade, é mais benéfico para os idiotai que a cidade viva em prosperidade como um todo, beneficiando assim todos os politai e fortalecendo a ideia de estado. Com efeito, se a pólis estiver a viver um período de florescimento, pode ajudar cada cidadão em particular a descobrir igualmente o caminho da prosperidade; pelo contrário, se um grupo de idiotai estiver bem, mas a cidade como um todo for destruída, também esse grupo acabará por ser arrastado para a desgraça coletiva. Por outras palavras: o conceito de idiotes convive bem com o de polites, enquanto a preocupação com o conforto privado não se sobrepuser aos imperativos da comunidade. Esse equilíbrio não é posto em causa mesmo quando os cidadãos mostram um nível diferente de envolvimento na condução dos assuntos da pólis. Com efeito, seria de esperar do cidadão comum que participasse nas reuniões da assembleia, do conselho e dos tribunais populares, embora nem todos tivessem igual disponibilidade para vir a ocupar cargos de topo, como acontecia, por exemplo, com as funções de arconte ou de estratego. O idiotes daria preferência a uma atividade cívica mais conotada com aqueles órgãos amplos, onde a sua intervenção ficaria um tanto diluída no meio da coletividade plural. Isso não impedia, obviamente, que o mesmo idiotes, voluntariamente e no uso pleno das suas funções cívicas, tomasse a iniciativa (bo boulomenos) de instaurar um processo ou de acusar 
alguém diante dos magistrados competentes. O seu estrato sociológico tornava-o, no entanto, menos disponível para planear as políticas da cidade-estado e para assumir uma posição de relevo ex officio, isto é, através do desempenho de cargos formais. É esta pequena nuance que o distingue do polites, conceito que se coaduna mais com o tipo de cidadão empenhado e, por conseguinte, mais apto para assumir a dianteira da pólis. Esta maior disponibilidade cívica revelada pelo polites abre caminho também a um primeiro grau de certa especialização, que, nas fontes, se traduz no recurso a expressões como hoi politeuomeno $i$ ('os que administram a polis') e, em especial, ao termo rhetores, para designar cidadãos mais interventivos, colocando igualmente a tónica na capacidade para convencer um auditório, através do uso eficaz da palavra. ${ }^{2}$

Ainda assim, durante o séc. v e também no iv, estas esferas de atuação cívica encontravam-se próximas o bastante para que a ação de idiotai e de politai pudesse coincidir no mesmo tipo de obrigações, sem risco de tensão. Isso mesmo decorre, de forma clara, da afirmação feita num discurso atribuído, embora com dúvidas, a Demóstenes. Trata-se do Contra Aristogíton II (26.5):

Tal como pensam que os idiotai lhes devem obedecer quando se encontram no governo (archein), da mesma forma devem eles obedecer com justiça às leis (nomoi) que governam (archein) a pólis, quando eles mesmos se tornam de novo idiotai.

Apesar de estabelecer uma hierarquia entre as pessoas que estão a exercer um cargo formal (archontes) por indicação da pólis e o cidadão comum (idiotes) que deve obedecer ao seu governo, o passo deixa evidente que o exercício de funções é efémero e que a real soberania cabe à lei (nomos), pelo que idênticas obrigações de obediência vincularão essas pessoas, assim que recuperarem o papel mais anónimo de idiotai.

Porém, este equilíbrio vai ser perturbado, de forma crescente, pelo esmorecimento da dinâmica da pólis (supra 1.1.3), que abrirá caminho à profissionalização a nível político e ao concomitante alheamento do cidadão comum em relação

\footnotetext{
2 Vide argumentação de Rubinstein (1998), 128-139, bem como a indicação de ocorrências destas expressões nas fontes, 142-143.
} 
aos assuntos da cidade-estado (supra 1.2.3). Essa evolução será, no entanto, marcada também por intensos conflitos armados e ideológicos, que deixarão marcas profundas na sociedade, ao mesmo tempo que irão permitir revelar personalidades de elevada estatura política e moral, ainda que não desprovidas de controvérsia. Na próxima secção, será abordada uma dessas figuras.

\subsection{Fócion: o último polites e os novos idiotai}

Apesar de o séc. IV constituir um período de grande vitalidade literária, sendo marcado por figuras indeléveis da cultura grega, como Platão, Aristóteles ou a maior parte dos oradores áticos, para evocar apenas alguns exemplos mais notáveis, ainda assim Atenas não mais recuperaria a hegemonia política e militar que detivera ao longo de boa parte do séc. v. De resto, nem Esparta nem nenhuma das outras póleis gregas conseguiriam ocupar de forma duradoira esse posto de referência, deixando assim espaço para a afirmação crescente da Macedónia, como se comentou já em secção anterior (supra 1.1.3). É este contexto histórico que servirá de pano de fundo à existência de Fócion, uma figura cuja atividade política se reparte entre a expetativa irrealista de recuperar o glorioso passado de Atenas e a necessidade concreta de negociar com os invasores os termos de uma submissão efetiva e humilhante para os padrões de autonomia a que Atenas estava habituada.

Talvez por isso mesmo, a biografia que dele escreveu Plutarco é, em certos aspetos, comparável à que compôs também para Alcibíades, em especial pela forma como a noção de kairos $^{3}$ pode surtir um efeito ambivalente na carreira de estadistas que, à partida, pareciam reunir condições de exceção para poderem triunfar. Tal como em Alcibíades, o kairos irá ser desfavorável a Fócion, mas por razões muito diferentes: o primeiro foi vítima do arrebatamento que gerava em si mesmo e nos outros, sendo em boa parte responsável por decisões altamente imprevidentes que ditariam o início do declínio do regime democrático, ao mesmo tempo que aniquilava as próprias hipóteses de ser um digno sucessor de Péricles

\footnotetext{
3 À letra 'ocasião favorável', mas que se pode interpretar também, de forma um tanto livre, no sentido de 'timing' político.
} 
(supra 1.1.2); quanto a Fócion, sucumbiu ao facto de ser talvez a pessoa com as qualidades certas, mas que não conseguiu ultrapassar a circunstância de viver num tempo desfavorável. ${ }^{4} \mathrm{E}$ ainda que Fócion não tenha estado envolvido em nenhum crime de asebeia ('impiedade'5), ao contrário de Alcibíades, é ainda assim particularmente significativo que, no termo da biografia, Plutarco compare a sua morte à de Sócrates, como dois exemplos de impiedade religiosa cometida pela imprevidência popular (infra 5.2.2). Por outro lado, embora Elêusis não ocupe, no caso de Fócion, uma importância comparável à que havia tido na existência de Alcibíades, vale a pena sublinhar que Plutarco recorre ao imaginário dos Mistérios para sublinhar também o 'timing' político de alguns dos momentos mais importantes da atuação de Fócion, pontilhando assim quer a via de ascensão quer o caminho da queda. ${ }^{6}$ É a análise desse trajeto que se propõe na última parte deste capítulo, pela forma como espelha a diluição crescente do universo da pólis e o fim de toda uma era.

\subsubsection{Sucessos militares e ascensão política de Fócion}

Alcibíades teve uma existência relativamente breve, mas ainda assim marcada por grandes aventuras e reviravoltas (supra 3.3). Fócion, pelo contrário, não só viveu durante mais tempo (entre 402 e 318), como ainda se distingue de Alcibíades em particular pelo facto - oportunamente sublinhado por Plutarco ${ }^{7}$ - de ter tido uma carreira notavelmente regular ao serviço de Atenas, a ponto de ser a pessoa que, até ao seu tempo, mais vezes ocupara o cargo de estratego (quarenta e cinco vezes). ${ }^{8}$ E apesar de preferir a paz e tranquilidade e de nunca promover,

4 De resto, a forma como Plutarco abre a biografia, comparando a atuação de Demades e de Fócion, é a clara expressão disso mesmo (Phoc. 1.1-6). Para mais pormenores sobre a forma como Plutarco aborda esta figura, vide Leão (2010c), de onde se retira alguma da argumentação agora apresentada.

5 Sobre a definição de asebeia e sobre as implicações legais decorrentes deste crime de natureza religiosa, vide infra 8.2 .1 .

6 A relação entre kairos, tyche e chronos, envolvendo a figura de Fócion, é analisada em Leão (2010c).

7 Phoc. 8.1-2.

8 Apesar de este número ser geralmente aceite como válido, Bearzot (1993), 124-127, põe em causa a sua exatidão histórica, argumentando com a ausência de confirmação noutras fontes — apenas Eliano se lhe refere indirectamente e de maneira vaga $(V H, 12.49)$. Bearzot acha, pelo contrário, que essa informação tem todo o ar de ser uma invenção de natureza apologética, que visava acentuar a superioridade de Fócion em relação a outros políticos, tanto seus contemporâneos como de períodos anteriores. 
de moto próprio, expedições militares, ainda assim nunca virou as costas a essas responsabilidades, também neste particular marcando um profundo contraste com Alcibíades, que não só inflamou o antigo interesse dos Atenienses pela Sicília, a ponto de os lançar numa campanha megalómana, como ainda foi mudando várias vezes de campo militar, ao sabor das suas ambições pessoais, mas sem nunca se identificar verdadeiramente com outro valor a não ser a própria vaidade. ' O contexto histórico de Alcibíades e o de Fócion são também bastante diferentes: o primeiro esteve ativo durante a Guerra do Peloponeso e poderia ter contribuído para evitar que Atenas caísse no atoleiro que ditaria a sua decadência enquanto potência militar; Fócion, pelo contrário, seria a pessoa certa para recuperar Atenas, se o seu estado de sujeição não fosse já tão adiantado. Com efeito, ele irá testemunhar a progressiva decadência política e militar de Atenas e a crescente afirmação da Macedónia com Filipe e Alexandre, bem como as incertezas e tumultos ligados aos primeiros anos de governo dos Diádocos. Ambos os estadistas tiveram os benefícios de uma boa formação - Alcibíades gozou do convívio privilegiado com Sócrates (Alc. 1.3; 4.1-4; 6.1-5; 7.4-5; 17.5), Fócion teve o magistério de Platão e Xenócrates (Phoc. 4.2) — e ambos acabaram por falhar, ainda que por motivos diferentes: Alcibíades por haver desbaratado a paideia socrática, bem como as suas naturais qualidades $;^{10}$ Fócion por ter vivido num tempo que já não era favorável a que as suas capacidades pudessem contrariar o declínio inelutável de Atenas. ${ }^{11}$

Ainda assim, a conjugação de qualidades inatas com uma paideia cuidada começa por marcar positivamente as primeiras empresas de Fócion, que teria desempenhado um papel decisivo na vitória de Naxos, na qual havia participado às ordens de Cábrias. Este detalhe biográfico não vem confirmado por nenhuma outra fonte diferente de Plutarco, além de que, em 376, Fócion teria somente 26 anos, portanto uma idade inferior à exigida para o posto de estratego. Por isso, a informação afigura-se pouco credível do ponto de vista histórico e não é improvável que o papel de Fócion no conflito tenha sido empolado, talvez para

\footnotetext{
9 Cf. Plutarco, Alc. 17.1-4.

10 Sobre a noção de Alcibíades como um produto falhado da paideia de Sócrates, vide Fialho (2008).

11 Realidade que Plutarco (Phoc. 3.2-5) de novo reforça ao comparar a situação de Fócion e de Catão o Jovem, na parte inicial (e por isso de certa forma 'programática') da biografia.
} 
compensar o facto de, até 349/8, não serem conhecidas outras empresas militares suas. ${ }^{12}$ Mesmo sendo assim, o facto de Plutarco querer destacar a juventude de Fócion com um feito marcante acaba também por ser revelador da forma como o biógrafo trabalhou a apresentação do estadista no que a este pormenor concreto diz respeito. ${ }^{13}$ Com efeito, à parte o problema das funções que Fócion terá desempenhado naquela batalha, há dois aspetos relevantes com ela relacionados cuja validade histórica não se põe em causa: em primeiro lugar, a vitória obtida em Naxos correspondia ao primeiro triunfo de Atenas, depois da derrota sofrida no termo da Guerra do Peloponeso e que obrigara a cidade a aceitar condições de paz humilhantes; ${ }^{14}$ em segundo, o facto de o triunfo ter ocorrido na altura em que se celebravam os Mistérios de Elêusis constituía um presságio favorável, indiciando talvez que Atenas estaria a começar a recuperação do seu antigo poder político e militar. Ao associar Fócion a estas circunstâncias duplamente positivas, Plutarco consegue sublinhar a grande expetativa que se concentrava sobre ele - aparentemente com a sanção divina, ao contrário do que acontecera com Alcibíades, na véspera da expedição à Sicília.

Contudo, as implicações irónicas desta sugestão discreta são esclarecidas na parte final da biografia, quando, uma vez confirmada a incapacidade para retomar a pujança do passado, Atenas se vê obrigada, logo a seguir à morte de Alexandre, a negociar com Antípatro os termos do acordo a celebrar com o dominador macedónio. É nesse momento doloroso que a cidade vai recorrer, de novo, a Fócion, como um dos seus interlocutores mais autorizados para enviar como embaixador. Uma das cláusulas mais duras do acordo firmado correspondia a aceitar o estabelecimento de uma guarnição macedónia em Muníquia, facto que era um sinal claro da dependência frente ao invasor. ${ }^{15}$ Ora é revelador que, neste momento difícil da existência da cidade, os Mistérios de Elêusis sejam de novo referidos por Plutarco (Phoc. 28.1-2):

\footnotetext{
12 Vide Bearzot (1993) 184; Alcalde Martín (2001) 48.

13 Cf. Plutarco, Phoc. 6.5-7.

14 Vide Hammond (1986) 418 e 488-489

15 Além de que garantia que a fação favorável à Macedónia (em cujas fileiras Fócion talvez se inserisse) poderia manter o poder em Atenas, conforme sustenta Bearzot (1993) 238-239 n. 174 e 178.
} 
E foi assim que os Atenienses receberam uma guarnição macedónia, comandada por Menilo, pessoa moderada e amiga de Fócion. Porém, esta determinação (prostagma) de Antípatro parecia arrogante e nela se viu a demonstração de uma autoridade fundada mais sobre a violência (bybris) do que uma ocupação decorrente dos acontecimentos. A ocasião (kairos) em que ocorreram [tais eventos] acrescentou-lhes não pouca emoção (pathos): com efeito, corria o vigésimo dia do mês Boedrómion, quando a guarnição foi instalada, durante a celebração dos mistérios, no próprio dia em que Iaco é conduzido, em procissão solene, da cidade para Elêusis. Perante a perturbação dos rituais iniciáticos, foram muitos os que compararam estas manifestações divinas recentes com outras mais antigas.

Ao evocar a vitória de Naxos (de 376), que serviu de antecâmara aos sucessos políticos e militares de Fócion, Plutarco havia sugerido, sem o dizer abertamente, que a coincidência desse evento com a realização dos Mistérios de Elêusis parecia servir de bom augúrio à expetativa de que Atenas estivesse no caminho de recuperar a importância perdida desde o fim da Guerra do Peloponeso. Porém, o desenrolar dos acontecimentos futuros veio mostrar que se tratara, afinal, de uma vã esperança. E a constatação dessa realidade fica patente quando a guarnição macedónia entra em Atenas, cerca de meio século depois (em 322), num claro sinal de submissão a Antípatro e de perda efetiva da liberdade. ${ }^{16}$ A sensação de um ciclo que se completa é, por conseguinte, acentuada pela circunstância de a entrada da guarnição na cidade ter coincidido com a celebração dos Mistérios de Elêusis. Plutarco usa o termo kairos para sublinhar toda a trágica ironia do momento, palavra que, sendo utilizada geralmente para referir a ideia de 'tempo oportuno', reforça agora o pathos provocado pela desmoralização dos. Atenienses. ${ }^{17}$ Ao fazer coincidir a chegada da guarnição macedónia com a celebração dos Mistérios, este kairos ou 'timing' político revela-se, apesar de tudo, ambivalente: a presença das forças macedónias era um sinal claro da crescente perda de independência de Atenas, mas criou também condições para que Fócion pudesse instituir um governo assente em critérios censitários, seguindo

\footnotetext{
16 Em termos ainda mais trágicos do que os vividos em 404, como sugestivamente sintetiza Hammond (1986) 648-649.

17 Por compreenderem que os deuses assistiam, com aparente indiferença, ao sofrimento geral da Grécia.
} 
aliás as indicações de Antípatro, que poderia constituir a saída possível naquelas difíceis circunstâncias. ${ }^{18}$

\subsubsection{O último dos politai: o fim de Fócion}

A entrada da guarnição macedónia em Atenas prepara, por outro lado, a descrição do fim político e biológico de Fócion. Acusado de traição pouco depois de haver negociado os termos do acordo, o estadista sofre na pele as consequências de uma nova época marcada pela falência dos ideais da pólis. A composição da assembleia que irá ditar a sua condenação à morte apresenta mimeticamente um claro sinal dessa realidade emergente, pois nela todos puderam tomar parte, sem distinção de estatuto ou de género, conforme sublinha Plutarco (Phoc. 34.3):

Foi então para lá que Clito os conduziu, guardando-os até que os magistrados tivessem reunido a assembleia (ekklesia). Nenhum escravo (doulos), estrangeiro (xenos) ou pessoa anteriormente privada de direitos cívicos (atimos) foi excluído: a todos, homens e mulheres, se concedeu o acesso à tribuna e ao teatro.

Não é de excluir a hipótese de que o biógrafo esteja a salientar o carácter irregular da reunião da assembleia, para acentuar, de certa forma, a ilegalidade da sentença de condenação que dela resultou. ${ }^{19}$ Em todo o caso, o panorama legal desenhado pelo autor aponta claramente para um ambiente de decadência generalizada da pólis, em que o afã da corrida aos antigos órgãos democráticos constitui apenas a afloração externa de uma realidade bem mais negra: a crescente

18 Phoc. 27.5. É muito significativo que este governo seja apresentado como um regresso à 'constituição ancestral' (patrios politeia). Embora este ideal propagandístico tenha contornos muito variáveis, pode aqui ser identificado com um regime político mais conservador e restritivo, que procurava, através do pagamento de um censo, reduzir as dimensões do corpo cívico habilitado a participar na condução da cidade. Plutarco parece ser favorável a esse governo, ao menos por comparação com a situação de anarquia política que viria a seguir. Sobre o surgimento e características do tema da patrios politeia, vide supra 3.3.

19 Diodoro, 18.66.4, sugere que seria uma assembleia regular, embora hostil a Fócion. Fialho (2010b), 202, chama a atenção para o facto de, em Plutarco, o julgamento de Fócion ser uma farsa democrática recriada pelo dominador macedónio: "For true citizens, the staged trial denounced the farsical democracy that was being acted out, making them aware of danger and demise - the 'shipwreck' of the city, in fact". 
incapacidade desses mesmos órgãos para tomarem decisões políticas verdadeiramente pertinentes, que fossem além do mero impulso imediato e básico de saciar o desejo de desforra popular.

Alguns parágrafos mais adiante (Phoc. 36-37), Plutarco estabelece um contraste nítido entre esta atmosfera dominada por baixos instintos e a grandeza de Fócion, que aceita, com a elevação própria da verdadeira arete política, a ingratidão dos concidadãos, que, pouco tempo antes, tinham recorrido à sua orientação avisada. A forma como o biógrafo descreve esta situação ajuda a configurar um quadro de implicações religiosas que estão claramente ao serviço de configurar um crime de natureza religiosa, cujos contornos preparam a exploração de um paralelismo com a morte de Sócrates, ocorrida na viragem do século (em 399), paralelismo esse que será finalmente assumido no termo da biografia. Com efeito e ao contrário do que aconteceu com o filósofo, cuja execução fora adiada para evitar a perturbação de diligências de natureza religiosa ${ }^{20}$ os acusadores de Fócion não hesitaram em contaminar toda a cidade, ao envolvê-la no sacrilégio de executar o estadista num dia solene dedicado a Zeus. Dado que Fócion havia sido acusado de traição, seria de esperar que o corpo fosse lançado fora dos limites do território ático, aí devendo permanecer insepulto, embora Plutarco acentue que tal ato era mais um sinal do carácter cruel e inumano dos inimigos de Fócion. ${ }^{21}$

No entanto, o ponto mais baixo da existência deste derradeiro polites prepara, por contraste, a sua reabilitação futura. ${ }^{22} \mathrm{E}$ para sublinhar essa recuperação, Plutarco opta por encerrar a biografia com a única descrição concreta que, ao longo da sua extensa obra, faz da morte de Sócrates. ${ }^{23}$ O biógrafo apresenta, assim, estas duas execuções como exemplos comparáveis de irreflexão humana, em dois momentos igualmente marcantes na história da pólis (Phoc. 38.5):

20 Bearzot (1993) 266 n. 253.

${ }_{21}$ De resto, se bem que seja uma simples indicação espacial, o facto de o biógrafo insistir (Phoc. 37.4) em que o corpo de Fócion foi levado 'para lá de Elêusis' salienta, simbolicamente, o completo abandono do estadista, cuja carreira foi pautada pelos Mistérios de Elêusis em momentos importantes e que agora se via despojado do próprio solo pátrio.

22 Da qual Plutarco é o único a dar notícia, se bem que esta informação esteja de acordo com a forma como o biógrafo concebeu a apresentação deste estadista. Vide Bearzot (1993) 267 n. 257.

23 Ainda que, como refere Geiger (1999), 358, Plutarco refira frequentemente Platão e Sócrates noutros pontos da sua obra. Sobre as semelhanças e diferenças na forma como apresenta a morte de Sócrates, Fócion e Catão, vide Alcalde Martín (1999); Trapp (1999). 
Contudo, os acontecimentos que rodearam a morte de Fócion reavivaram entre os Gregos a lembrança da morte de Sócrates: com efeito, representaram ambos para a cidade (polis) um erro (hamartia) e um infortúnio (dystychia).

Este desfecho da biografia de Fócion convida o leitor a retomar de novo o contraste entre Alcibíades e Fócion, referido na secção anterior (5.2.1). Com efeito, para o ateniense comum, o crime mais grave de impiedade religiosa (asebeia) havia sido não o que estivera na base do processo de Sócrates, mas sim o que fora motivado pelos escândalos de 415, nos quais Alcibíades havia sido diretamente envolvido e que, numa das suas formas, se consubstanciara numa paródia aos Mistérios de Elêusis. Para Alcibíades, o envolvimento neste crime teve um impacto determinante na sua carreira, pois aconteceu num momento particularmente sensível da história ateniense. Esse kairos seria aproveitado pelos seus inimigos políticos, mas levaria igualmente a que ele estudasse com cuidado o 'timing' adequado para, mais tarde, regressar a Atenas. ${ }^{24}$ No entanto, os danos que acumulara a sua imagem pública, bem como as elevadas expetativas em si colocadas pelos concidadãos - e que ele mesmo alimentara — levaram-no de novo à perdição, desbaratando irremediavelmente notáveis qualidades inatas, bem como a paideia e dedicação de Sócrates.

No caso de Fócion, as referências a Elêusis marcam também, de forma cadenciada e insistente, o seu 'timing' político, desde os inícios auspiciosos da batalha de Naxos, até às difíceis negociações com Antípatro e à execução final. Mas se, com Alcibíades, foi a própria atuação arrebatada que configurou um crime de asebeia, com Fócion é o comportamento dos concidadãos que representa um crime de impiedade, comparável, em magnitude, ao que tirara a vida a Sócrates. E assim, enquanto Alcibíades desperdiçara as vantagens do convívio próximo com Sócrates, Fócion, pelo contrário, aparece representado como um digno sucessor do filósofo, apesar de as circunstâncias do contexto histórico em que viveu não lhe permitirem desenvolver totalmente uma arete que fazia dele um carácter de exceção.

Nesta perspetiva, o erro (hamartia) representado pela sua execução é duplamente trágico, pois sublinha o perigo da irreflexão e da histeria coletivas, quando

\footnotetext{
24 Fazendo com que esse retorno coincidisse com a sua reabilitação a nível religioso, pela forma como escoltou a pompe ('cortejo' solene) dos Mistérios de Elêusis.
} 
alienam por completo a dignidade política, bem como o desperdício inglório de um dos poucos arrimos de esperança com o qual os Atenienses poderiam contar neste momento de enorme desorientação. É também altamente significativo que a biografia termine com a ideia de que a morte de Fócion constitui uma expressão de 'infortúnio' (dystychia) ou de 'má fortuna', ligando-se assim, em anel, às afirmações tecidas no início do relato (supra 5.2.1): apesar de ser naturalmente dotado de arete e de ter usufruído da paideia adequada, seria necessário a Fócion ter contado com o apoio de uma sorte (tyche) favorável e de ter vivido num tempo mais conveniente para que as suas qualidades se tivessem desenvolvido em toda a plenitude. Mas sendo adversas as circunstâncias, o último dos politai acabaria por sucumbir à torrente descontrolada dos idiotai, embriagados pelo mediatismo dos seus interesses momentâneos.

Assim desaparecia a energia cívica que alimentara uma das mais emblemáticas póleis da Hélade, para se diluir, reinventada, na cultura refinada do universo cosmopolita da época helenística. A análise de alguns dos agentes e sintomas dessa notável transformação constituirá o assunto dos próximos capítulos (infra 6 e 7). 


\section{ALEXANDRE MAGNO DA ESTRATÉGIA PAN-HELÉNICA AO COSMOPOLITISMO ${ }^{1}$}

\subsection{Alexandre: história, biografia e amplificação lendária}

Embora Alexandre se tivesse, desde cedo, rodeado de historiadores oficiais empenhados em fixar para a posteridade os feitos notáveis deste líder carismático, num misto de glorificação da figura do soberano e de propaganda política deliberada, o certo é que se perderam os relatos das pessoas que tinham presenciado os eventos narrados ou que deles haviam tido um conhecimento próximo a partir do testemunho direto de outros. ${ }^{2}$ Por este motivo, as informações agora disponíveis para reconstituir a atuação de Alexandre acabam por ser facultadas por autores que viveram alguns séculos depois do chefe macedónio. E assim, das cinco principais fontes que chegaram até nós (Diodoro Sículo, Cúrcio Rufo, Plutarco, Arriano e Justino), o relato mais recuado no tempo (o livro XVII da Biblioteca de Diodoro) foi escrito apenas na segunda metade do séc. I a.C., embora tanto ele como os restantes se baseassem na obra hoje perdida de outros autores mais antigos, facto que ajuda a sustentar a fiabilidade dos elementos transmitidos, mas não isenta de sérias dificuldades a sua correta interpretação, uma vez que os dados são, por vezes, incompatíveis entre si. Nesta abordagem da figura de

\footnotetext{
1 Neste estudo, recupera-se o essencial da abordagem feita em Leão (2005a), adaptando-a embora aos objetivos específicos deste volume e explorando novos dados, relacionados em particular com a educação de Alexandre.

2 Sobre a propaganda ideológica e política relacionada com a figura do chefe macedónio, vide Muccioli (2005), esp. 105-116.
} 
Alexandre, será evocado, sobretudo, o testemunho de Plutarco, se bem que cruzado com a informação facultada por outras fontes. ${ }^{3}$

São bem conhecidos dos estudiosos de Plutarco os momentos em que o polígrafo de Queroneia reflete sobre os motivos que o terão levado a escrever vidas paralelas de pessoas ilustres do passado grego e romano. De facto, na abertura do prefácio às Vitae de Timoleonte e de Emílio Paulo (Aem. 1.1), Plutarco informa que começou por se dedicar à elaboração de biografias a pedido de amigos, entre os quais se contavam personalidades importantes, tanto gregas como romanas. Contudo, a essa motivação cedo ele juntou o gosto e proveito pessoais decorrentes do convívio com o exemplo das grandes figuras do passado. Portanto, será de admitir que a elaboração de uma espécie de 'espelho de virtudes' constitui um dos objetivos principais da sua escrita biográfica. No entanto, a concomitância, no passo acima referido, do conceito de 'história' tem levado muitos investigadores a procurar descobrir em Plutarco as marcas da indagação histórica, com resultados nem sempre elogiosos para o autor das Vitae. Em boa verdade, e prevendo a defesa contra certamente críticas dessa natureza, o próprio Plutarco teve o cuidado de esclarecer os objetivos que o guiaram ao escrever retratos paralelos, conforme acontece ao abrir a biografia de Alexandre Magno: ${ }^{4}$

Ao escrevermos neste livrinho a biografia (bios) do rei Alexandre e de César (que derrubou Pompeio), não faremos outros preâmbulos, dada a grande quantidade de acontecimentos envolvidos, para além de formular um pedido aos leitores: de, no caso de não relatarmos em pormenor todo e cada um dos eventos célebres, mas antes abreviarmos a maior parte, nos não julgarem mal. Na verdade, nós não escrevemos histórias (historiai) mas sim biografias (bioi), nem é tão pouco nos acontecimentos mais espetaculares que reside especialmente a demonstração da virtude ou do vício. Pelo contrário, muitas vezes um pequeno gesto, uma palavra ou uma brincadeira refletem melhor o carácter do que os combates com baixas incontáveis ou fileiras cerradas ou os maiores cercos a cidades.

\footnotetext{
3 Para um conspecto das fontes antigas relativas a Alexandre e dos problemas que a respetiva interpretação coloca, vide Heckel \& Yardley (2004) xx-xxıx.

4 Alex. 1.1-2.
} 
Este preâmbulo, justamente célebre, não só define de maneira mais precisa a índole das Vitae como esclarece melhor os seus objetivos, que já se adivinhavam no primeiro passo evocado. Plutarco não pretende ser um historiador, mas antes um biógrafo. Por este motivo, pede aos leitores que lhe não censurem o facto de passar em branco acontecimentos que, pela sua importância, eram bem conhecidos e sobre os quais havia à disposição outros relatos de natureza histórica. Na verdade, há que reconhecer que seria mais fácil aos leitores do tempo do biógrafo do que aos estudiosos modernos acatar o pedido formulado. É que, conforme acima se dizia, muitas das obras e autores que então existiam mais não são hoje do que simples nomes cuja produção se perdeu, faltando portanto esse tipo de informação complementar para quem busca elementos para uma análise mais marcadamente histórica.

Plutarco é por conseguinte um biógrafo, mas também não na forma plena em que hoje se entende o termo. As Vitae não pretendem descrever a carreira de determinado homem ou mesmo definir o lugar que ocupa na história, embora possam acabar por fazê-lo, até porque as personalidades retratadas correspondem geralmente a grandes estadistas do passado. Os feitos destes heróis, qualquer que fosse a sua natureza, só lhe interessavam na medida em que permitissem esclarecer e iluminar a verdade sobre o carácter que possuíam essas personalidades de exceção. Na abordagem que agora se propõe, será advogada uma aplicação ainda mais restrita deste princípio enunciado, dado que não se pretende analisar e reconstituir todos os aspetos ligados à vida de Alexandre, mas privilegiar somente os que contribuem para ilustrar um tema específico e com uma pertinência direta para o assunto deste livro: a evolução política e ideológica que, no decurso das campanhas militares, o macedónio parece ter seguido e que o conduz de uma estratégia pan-helénica para um ideal de cosmopolitismo, que o seu império acabaria por ilustrar de forma prática. Aliás, a capacidade empreendedora do jovem soberano constitui um dos traços apreciados por Plutarco, que, no tratado Sobre a fortuna ou virtude de Alexandre Magno (328a-e), apresenta Alexandre como um filósofo que é capaz de levar à prática (ergon) o que outros conseguiram atingir somente pela exposição teórica (logos). 5

\footnotetext{
5 Nisto se distinguindo, pela positiva, de figuras como Platão, cujas Leis poucos leram, enquanto milhares e milhares de pessoas se nortearam pelas normas estabelecidas por Alexandre. Ao fazer esta apreciação, Plutarco aproximava-se do bem conhecido juízo de Onesícrito sobre Alexandre, a quem considerava um "filósofo em armas" (FGrHist $134 \mathrm{~F}$ 17a36-7).
} 


\subsection{Os Gregos e o ideal pan-helénico}

Dado que a primeira parte da análise se irá centrar no conceito de pan-helenismo, convirá recordar alguns aspetos ligados à formação deste princípio propagandístico, cujas raízes serviam o apelo ao patriotismo grego. Na verdade, a proposta de uma união pan-helénica perpassa muitos dos autores dos sécs. v e iv, a ponto de tornar-se numa ideologia muito divulgada no meio intelectual. ${ }^{6}$ De resto, assentava igualmente em bases populares, pois até o cidadão anónimo poderia constatar com facilidade, no plano empírico, os efeitos positivos da união produzida pela resistência grega às invasões persas de 490 e de 480, bem como o depauperamento generalizado a que a Guerra do Peloponeso conduzira as cidades-estado gregas (supra 1.1 .1 e 1.1.2). No entanto, aquilo que, em termos teóricos, se afigurava claro e pertinente, enfrentava, na prática, o enorme óbice decorrente do particularismo próprio do sistema da pólis. É por isso que, para se ativar a união helénica, teria de verificar-se a premência de poderosos fatores externos: ou o perigo iminente de uma devastadora invasão exterior ou a capacidade para alguém se impor como hegemon ('chefe') aos restantes estados gregos. Os Persas justificavam o primeiro cenário, representando também, por esse motivo, no imaginário helénico, a imagem acabada do bárbaro que era necessário combater; as campanhas vitoriosas de Filipe e a Liga de Corinto vieram fornecer ao jovem soberano da Macedónia a força e o enquadramento legal necessários para fazer dele o condutor natural dos Helenos nessa campanha pela civilização.

No entanto, apesar de historicamente justificada, esta solução também comportava certos riscos, como claramente decorre da referência, ainda que breve, às posições de dois dos intelectuais que mais defenderam, embora por vias opostas, a ideologia pan-helénica: Isócrates e Demóstenes.7

A vida longa do orador Isócrates permitiu-lhe assistir ao desenrolar de quase um século de movimentada história de Atenas. Nascido em 436, haveria de perecer em 338, ano em que Filipe derrotara os Gregos em Queroneia, batalha que ficou como símbolo da inevitável perda futura da autonomia real das póleis

\footnotetext{
6 Tema estudado, com ampla argumentação e estudos das fontes, por Ferreira (1992).

7 Tanto mais que a posição da Macedónia perante os outros estados gregos acabava por ser um tanto ambígua e desfavorável a uma eventual hegemonia, já que os Macedónios eram considerados gregos de segunda categoria ou até mesmo bárbaros. E.g. Heródoto, 5.22.2; Demóstenes, 1.17, 24.
} 
helénicas. De resto, a tradição antiga contava que o orador morrera de angústia e desânimo ao ouvir a notícia da derrota grega e ao compreender os desejos imperialistas de Filipe ${ }^{8}$ — ou então, como pretendem outros, por esse desgosto provir da impossibilidade de aplicar finalmente o seu ideal de pan-helenismo, já que os Atenienses continuavam a insistir na resistência ao chefe macedónio. Apesar de não ser um orador que cultivasse a intervenção pública, a vontade de participar na política obrigou Isócrates a recorrer ao discurso fictício, elevado às alturas de género literário, que integrava nas lições de retórica e fazia circular, depois, sob a forma de panfletos.? Ora um dos elementos constantes no seu pensamento político é a ideia de um pan-helenismo consubstanciado na união de todos os Gregos contra o bárbaro. Este princípio básico foi evoluindo ao longo da sua vida no que diz respeito ao elo capaz de garantir a união desejada, desde a dupla hegemonia de Atenas e Esparta até à figura de um monarca que, de acordo com os tempos, conheceu intérpretes como Jasão de Feras, Dionísio de Siracusa, Nícocles de Chipre, Arquidamo de Esparta e Filipe da Macedónia. Estas convicções, aliadas à grande experiência de quase um século de vida, levaram-no a aproximar-se de tiranos, a admirar certas qualidades da monarquia, a nutrir determinadas simpatias oligárquicas, se bem que, mesmo nos momentos em que criticava a democracia, o fizesse ainda com intenção de aperfeiçoá-la à luz dos bons exemplos do passado. ${ }^{10}$

Demóstenes, por seu lado, acompanha de perto, até à morte (322), as tentativas de Atenas para recuperar a influência perdida e é com os altos e baixos dessas movimentações que se combina a própria carreira do ilustre orador. Em termos ideológicos, Demóstenes não está muito distante de Isócrates, cujo pan-helenismo partilha, bem como o princípio básico da união de todos os Gregos contra o inimigo bárbaro. Diferem, porém, num ponto essencial: para Isócrates, o inimigo encontrava-se, de acordo com a visão usual no séc. Iv, representado pelos Persas e, entre outros candidatos, viu em Filipe uma garantia séria da agregação helénica. Não assim Demóstenes, para quem o adversário estava

\footnotetext{
8 Pausânias, 1.18.8.

9 Como defende Too (1995), 10-35, a melhor forma de definir globalmente a obra de Isócrates (com exceção dos discursos forenses) seria a expressão, usada pelo próprio orador, de logos politikos.

10 Assim pensa Mathieu (1966), 126-139 e passim, que crê que o regime político defendido por Isócrates tende a identificar-se com a democracia moderada, na esteira dos ideais de Terâmenes.
} 
situado a norte, na Macedónia. De alguma forma, a história acabaria por dar razão a ambos, já que a união dos Gregos, embora forçada, e a difusão da cultura helénica foram duas das importantes consequências da ação de Filipe e de Alexandre; por outro lado, o domínio exercido pela Macedónia, conforme previra Demóstenes, significara de facto o fim da liberdade helénica, nos termos que até então haviam caracterizado as póleis gregas. ${ }^{11}$

\subsection{Alexandre e a estratégia pan-helénica}

À parte estas divergências no campo teórico, o certo é que a ideologia pan-helénica serviu a Filipe para reforçar a posição de líder e preparar a invasão da Ásia, se bem que o seu assassinato (em 336) o tenha impedido de avançar com o projeto. Caberia a Alexandre, então, a tarefa de pôr em prática essa ambiciosa campanha, que, de resto, servia também os desejos expansionistas que igualmente nutria e a vontade de emular ancestrais seus (em particular Héracles e Aquiles). ${ }^{12}$ De resto, a Guerra de Troia era apontada às vezes pelos antigos como a causa última para justificar a inimizade entre Gregos e Persas, ${ }^{13}$ pelo que não é improvável que, no imaginário de Alexandre, a campanha contra a Ásia pudesse representar uma espécie de reedição desse glorioso conflito, desta vez com ele à cabeça de um contingente pan-helénico. Não surpreende, por isso, que

11 Há, no entanto, que reconhecer que a mudança maior foi experimentada sobretudo por grandes cidades como Atenas e Esparta, que estavam habituadas a polarizar à sua volta o mundo grego. A primeira perdeu esse papel com a Guerra do Peloponeso; a segunda, com o desfecho da batalha de Leuctras. Mas, para as restantes póleis, as relações estabelecidas com a Macedónia e com os reinos helenísticos permitiam alguma autonomia interna e um sistema de alianças semelhante ao que operavam com as anteriores potências. Em todo o caso, há que reconhecer que as cidades-estado perdiam o particularismo que as distinguia, ao ficarem integradas num mundo bastante mais vasto. Vide supra 1.2.4.

12 Flower (2000), 101-102, refere que, embora se desconheçam as verdadeiras motivações destes dois chefes macedónios, não é improvável que, à vontade de alargar os ganhos e as conquistas, Filipe e Alexandre associassem a consciência de que, enquanto descendentes de Héracles, deveriam imitar a ação benfazeja do herói relativamente aos Gregos. Aquiles, por seu lado, era uma referência constante no imaginário de Alexandre: segundo Plutarco (Alex. 5.8), Lisímaco — um dos pedagogos do futuro rei — intitulava-se a si mesmo Fénix, Aquiles ao jovem pupilo, e Peleu a Filipe. De acordo ainda com o mesmo biógrafo (Alex. 24.10-14), durante o assédio a Tiro, Alexandre iria arriscar a vida para salvar Lisímaco, que teimara em segui-lo em campanha, por achar que não era nem mais débil nem mais velho do que Fénix, que acompanhara Aquiles até Troia.

13 E.g. Heródoto (1.4-5), que interpreta as invasões de Dario e de Xerxes como consequência natural daquele confronto passado. 
a primeira etapa cumprida depois da travessia do Helesponto tenha sido uma paragem em Troia, onde o jovem macedónio prestou homenagem a Atena e aos heróis caídos, em particular a Aquiles, "a quem considerava afortunado, porque, em vida, tivera um amigo dedicado e, depois de morto, um excelente arauto" da sua fama. ${ }^{14}$

Depois desta breve paragem em Troia, Alexandre juntou-se ao grosso das tropas e preparou-se para enfrentar a primeira batalha, muito importante do ponto de vista psicológico, pois marcaria a entrada na Ásia e a afirmação do génio militar do macedónio, capaz de alcançar a vitória em situações de guerra que lhe eram, à partida, desfavoráveis. Trata-se da espera que os Persas fizeram às forças invasoras junto das margens do rio Granico. Parménion, um dos generais de Alexandre, aconselhou-o a aguardar pelo dia seguinte para avançar, mas o jovem rei, que tinha uma capacidade impressionante de leitura dos cenários militares, decidiu avançar de imediato, "dizendo que envergonharia o Helesponto se, depois de o ter atravessado, ficasse com receio do Granico". ${ }^{15}$ As forças persas contavam, entre as suas fileiras, com vinte mil mercenários gregos de infantaria, que eram igualmente combatentes com experiência. Plutarco (Alex. 16.13-14) afirma que os mercenários pediram ao macedónio que lhes poupasse a vida, mas Alexandre, que sabia que poderiam voltar a alistar-se novamente pelos Persas, carregou furiosamente sobre eles, movido mais pela raiva do que pela razão. ${ }^{16}$ Cerca de dois milhares dos homens que integravam aquele contingente foram aprisionados e remetidos para a Macedónia, onde serviriam na condição de escravos.

Não há razão para ver nestes mercenários uma oposição organizada dos Gregos aos avanços do soberano macedónio, pois os mercenários, por definição, combatem por quem lhes paga, sem outras motivações ideológicas que não sejam o lucro rápido. Ainda assim, o tratamento exemplar decidido por Alexandre devia-se, certamente, ao facto de eles serem Gregos e de, portanto, a sua primeira obrigação ser a de combaterem ao lado dos compatriotas por um objetivo

\footnotetext{
14 Alex. 15.8.

15 Alex. 16.3.

16 Hammnond (1997), 69, é de opinião que esta crítica implícita à forma 'apaixonada' como Alexandre atuou terá sido formulada por Aristobulo, que deve estar por detrás do relato de Plutarco, neste ponto em concreto.
} 
comum. ${ }^{17}$ De resto, que o desígnio pan-helénico estava na cabeça de Alexandre provam-no as diligências que fez relativamente ao despojo, conforme ilustra o relato de Plutarco (Alex. 16.17-19):

Porque desejava que os Helenos partilhassem a vitória, mandou aos Atenienses, em particular, trezentos escudos retirados aos prisioneiros e, como disposição geral, ordenou que se inscrevesse sobre os restantes despojos esta epígrafe plena de orgulho: «Alexandre, filho de Filipe, e os Gregos (com exceção dos Lacedemónios) conquistaram-nos aos bárbaros que habitam na Ásia.»

Depois de vários outros recontros, a grande batalha com Dario III iria dar-se em Gaugamelos. ${ }^{18} \mathrm{Na}$ iminência do confronto decisivo, Alexandre fez um discurso de incitamento aos vários contingentes que constituíam as suas tropas, as quais lhe gritaram, em resposta, a confiança que nele depositavam como chefe para os liderar contra os bárbaros. ${ }^{19}$ Nesta altura, portanto, Alexandre continuava a movimentar-se dentro da estratégia pan-helénica da campanha contra a Ásia. De resto, essa posição saiu reforçada ainda pelas ações que levou a cabo depois de obter a vitória, em termos que valerá a pena recordar na íntegra, seguindo ainda o relato do mesmo biógrafo (Alex. 34.2-3):

Desejoso de ganhar o favor dos Helenos, escreveu-lhes a informar que todas as tiranias haviam sido abolidas e que agora se governavam por si mesmos, dizendo em particular aos Plateenses que lhes iria reconstruir a cidade, pois os seus antepassados tinham posto o território à disposição dos Helenos para lutarem pela liberdade. Enviou ainda para Itália, aos Crotoniatas, parte dos despojos, em homenagem à determinação e coragem do atleta Faulo, o qual, durante as Guerras Médicas, numa altura em que todos os Itálicos recusaram auxílio aos Helenos, navegou para Salamina com uma nau equipada às suas custas, tomando assim parte nos mesmos perigos.

\footnotetext{
17 Em vez disso, aliaram-se ao bárbaro contra os outros Helenos; cf. Arriano, 1.16.6.

18 Para uma reconstituição e análise da batalha de Gaugamelos, vide Monteiro (2012).

19 Cf. Plutarco, Alex. 33.1.
} 
Com estas diligências, Alexandre deixava claro o objetivo de relacionar a campanha que agora empreendia com as Guerras Medo-persas: as promessas feitas aos Plateenses evocavam a batalha de Plateias; os despojos enviados a Crotona lembravam a recontro de Salamina. Desta forma, estabelecia-se uma conexão direta entre os dois momentos mais altos da resistência grega ao avanço persa, por um lado, e a vitória de Gaugamelos, por outro. Em comum tinham o desfecho altamente positivo que resultou da formação de uma aliança pan-helénica contra o inimigo bárbaro.

Com esta retumbante vitória, Alexandre garantia que Dario, mesmo sem ter ainda morrido, já não conseguiria reunir novo exército imperial que combatesse o contingente grego liderado pelos Macedónios. A derrota dos Persas franqueava, igualmente, o caminho para o domínio de toda a Ásia, com as gloriosas cidades de Babilónia, Susa e Persépolis incluídas. Ao longo destas conquistas, Alexandre foi praticando alguns atos que se entendem ainda na mesma lógica de operação de vingança contra o bárbaro invasor: depois da captura de Susa, fez diligências no sentido de que fossem devolvidas a Atenas as estátuas de Harmódio e Aristogíton, bem como a de Ártemis, que Xerxes havia roubado. ${ }^{20}$

Porém, o ato mais simbólico da vitória grega diz respeito à tomada de Persépolis e à destruição do palácio imperial. São particularmente significativas as palavras de Demarato de Corinto (que havia sido já amigo de Filipe), ao contemplar Alexandre sentado no posto de Dario pela primeira vez: "desatou a chorar, como fazem os velhos, e a dizer que haviam sido privados de um enorme prazer os Helenos que tinham morrido antes de ver Alexandre sentado no trono de Dario". ${ }^{21}$ Esta opinião é expressa por alguém que nutria óbvias simpatias pela Macedónia e pela Liga de Corinto. No entanto, o próprio Plutarco revela, num ponto da Vida de Agesilau (15.4), que, em sua opinião e na de muitos Gregos contemporâneos dos eventos, havia mais razão para chorar os Gregos (e em particular os Espartanos) que haviam perecido em Leuctras, Queroneia, Corinto e na Arcádia, do que o facto de não terem visto Alexandre sentado no trono de Dario. Quer isto dizer, naturalmente, que nem todos os Gregos viam no macedónio o begemon natural dos Helenos.

\footnotetext{
20 Cf. Arriano, 3.16.

21 Plutarco, Alex. 37.7.
} 
Quanto à ideia de queimar o palácio de Persépolis, a tradição divide-se. A explicação oficial e também a mais provável é a de que o incêndio foi uma forma de retaliar contra as invasões persas, em particular os atos de sacrilégio perpetrados contra os templos gregos. ${ }^{22}$ Além disso, este ato destrutivo comportava em si um poderoso efeito psicológico, capaz de reforçar quer a sujeição dos Asiáticos quer ainda a fidelidade a Alexandre contra os Espartanos e outras ameaças de rebelião. Corria, no entanto, uma outra versão, ecoada no relato de Plutarco (Alex. 38), segundo a qual a decisão de queimar o palácio fora tomada sob a influência de Taís (uma famosa cortesã ateniense), num momento de irreflexão e por um Alexandre embriagado que rapidamente se arrependeu do passo que acabara de dar. O mais provável, no entanto, é que o gesto fosse premeditado e que esta segunda versão seja apenas uma forma de romancear um evento do qual resultara a destruição de uma das maravilhas arquitetónicas do mundo antigo. Aliás, antes do incêndio, não é improvável que Alexandre tenha aberto o palácio ao saque desordenado dos Macedónios, como parece indicar o facto de inúmeros pequenos objetos de ouro e de pedras preciosas terem ficado esquecidos no chão, conforme ilustram as escavações arqueológicas. ${ }^{23}$

\subsection{Alexandre e o caminho do cosmopolitismo}

Depois dos eventos referidos na secção anterior, a coligação pan-helénica havia atingido os grandes objetivos que justificaram a sua intervenção: como hegemon dos Helenos, Alexandre havia garantido a libertação das cidades gregas da Ásia Menor e a vingança contra os Persas. Prova de que este primeiro objetivo estava concluído é o facto de Alexandre ter dispensado os contingentes aliados no ano de 330, em Ecbátana, se bem que numerosos veteranos optassem por permanecer como mercenários. ${ }^{24}$ Não quer isto dizer que o macedónio abandonasse definitivamente os ideais pan-helénicos, tanto mais que poderiam

\footnotetext{
22 Cf. Arriano, 3.18.12; Estrabão.15.3.6.

23 Sobre esta questão, vide Hammond (1997) 114-115.

24 Arriano, 3.19.5-6; Diodoro, 17.74.3.
} 
vir a ser-lhe úteis novamente, em caso de necessidade. ${ }^{25}$ No entanto, a partir desta altura Alexandre irá mostrar-se cada vez mais permeável à progressiva influência oriental, uma atitude que era, de certa forma, contrária à propaganda da união dos Gregos contra o bárbaro. Iria, no entanto, contribuir para a paulatina fusão étnica e cultural de Europeus e Asiáticos, abrindo assim caminho ao cosmopolitismo da época helenística. Trata-se de uma questão complexa e muito debatida, mas valerá a pena evocar alguns dos sinais exteriores dessa mudança e também as reservas que inspirava nos Gregos, em particular nos veteranos macedónios, que receavam as consequências desta abertura do soberano aos anteriores inimigos.

Não obstante o facto de Aristóteles — um dos mestres de Alexandre partilhar a bem conhecida perspetiva de que os Gregos eram superiores aos bárbaros, ${ }^{26}$ o certo é que o jovem rei mostrou, desde cedo, desejo de aplicar medidas conciliatórias, quer por simples pragmatismo político, quer talvez por convicção crescente. ${ }^{27}$ Afigura-se provável que a realidade correspondesse a uma conjugação em grau variável destes dois fatores, mas o certo é que várias das medidas de Alexandre se traduziram numa promoção efetiva da fusão entre Europeus e Asiáticos. ${ }^{28}$

Isso é visível, por exemplo, na distribuição de cargos administrativos, concedidos a macedónios da confiança do rei (geralmente pessoas que integravam o seu ciclo de amigos mais chegados), mas também a persas que foram, várias vezes, reconduzidos como sátrapas; no facto de permitir a Ada de Halicarnasso que o adotasse como filho, ou na maneira como se mostrou respeitoso em relação à mãe e esposa de Dario. No plano formal, Alexandre acolheria, ainda, certos aspetos da indumentária e do protocolo persas, sendo o mais controverso a tentativa de implementar a demonstração ritual de obediência ao soberano, conhecida pelo termo proskynesis ('prostração'). Tem-se especulado muito em relação à

25 Flower (2000), 115-135, advoga, com algum excesso de boa vontade, a perspetiva de que o ideal pan-helénico se manteve praticamente intacto.

26 E.g. Politica, 1252b.

27 O problema das verdadeiras intenções de Alexandre continua a alimentar controvérsia entre os estudiosos do soberano macedónio. Vide Tarn (1933) e Badian (1958), para um exemplo de duas posições clássicas e antagónicas na forma de entender o 'sonho de Alexandre' de construir a união da humanidade ou a irmandade do ser humano.

28 As fontes relativas ao relacionamento de Alexandre com os bárbaros encontram-se reunidas em Heckel \& Yardley (2004) 175-188. 
simbologia deste cerimonial, se bem que deva ser incorreto ligá-lo a uma simples estratégia de divinização por parte de Alexandre, conforme sustentam algumas fontes. De facto, os Persas usavam o ritual como forma de deferência estatutária, sem que isso devesse implicar — mesmo quando era dirigida aos soberanos - a ideia de que se estava a adorar um deus. ${ }^{29}$ No entanto, aquilo que, na ótica de um persa, representava apenas a continuação de um cerimonial antigo, para um grego simbolizava uma humilhação, já que somente os deuses seriam merecedores de uma prostração em sinal de obediência. Por isso, Alexandre enfrentou resistência da parte de Gregos e Macedónios, embora a sua intenção talvez fosse apenas a de colocar todos os súbditos num plano semelhante de relacionamento com o soberano. ${ }^{30}$

Idênticos planos de fusão étnica e cultural devem ter assistido à promoção de casamentos mistos entre Europeus e Asiáticos (em Susa, 324), que envolveram quase uma centena de hetairoi e philoi de Alexandre e mulheres nativas de elevado estatuto social. As cerimónias foram diretamente patrocinadas pelo soberano, que nelas tomara parte igualmente de forma ativa. ${ }^{31}$ Com esta iniciativa, Alexandre pretendia, certamente, reforçar a sua legitimidade no trono aqueménida, mas visava também criar uma renovada geração de governantes, retirada precisamente da fusão entre dois blocos étnicos tradicionalmente inimigos. O mesmo objetivo assistiria, também, à fundação de novas cidades, que permitiriam não apenas fixar populações nómadas e potencialmente perigosas, como ainda facilitar a convivência pacífica entre as guarnições destacadas por Alexandre e as populações locais, tornando esses centros urbanos em pólos de irradiação cultural helénica e de vitalidade económica. ${ }^{32}$

29 Já Heródoto (1.134) explicara nestes termos a lógica que assistia ao ritual da proskynesis.

30 Guthrie (1981), 36-43, crê que o comportamento do antigo pupilo relativamente aos bárbaros terá, de alguma forma, chocado Aristóteles; este 'desvio' em relação aos ensinamentos do mestre, bem como o facto de Calístenes (aluno e sobrinho do Estagirita, que acompanhara Alexandre em campanha, como historiador) ter acabado por morrer no contexto da oposição ao ritual da proskynesis, fizeram com que a figura de Alexandre se tornasse um tanto odiosa aos Peripatéticos, embora não seja seguro que o efeito sobre Aristóteles tenha sido o mesmo.

31 Foi nessa altura que ele desposou Estatira e Parisátis, filhas, respetivamente, de Dario III e de Artaxerxes III Oco. Segundo Plutarco (Alex. 70.3), a cerimónia contou com nove mil convidados, os quais foram todos agraciados com presentes.

32 Vide Hammond (1989) 264-267. Segundo Plutarco (De Alex. fort. aut virt. 328e), Alexandre teria fundado setenta novas cidades, que, por norma, começavam com um corpo de 10.000 cidadãos homens. 
Uma justificação semelhante deve ter assistido à decisão de industriar jovens nativos na língua e táticas militares dos vencedores. Plutarco expõe a medida nestes termos (Alex. 47.5-6):

Entretanto, ele procurava adaptar-se cada vez mais à forma de vida das gentes locais, e a estas tentava acomodá-las aos costumes macedónios. Tinha para si que a fusão (anakrasis) e a partilha (koinonia) eram melhores do que a força para amigavelmente conseguir estabilizar a situação, quando estivesse ausente em longas viagens. Em consequência e uma vez selecionados trinta mil jovens (paides), ordenou que lhes fosse ensinada a língua grega e que os industriassem no uso das armas macedónias, tendo, para isso, destacado muitos instrutores.

Com a iniciativa aqui descrita, Alexandre estava a instituir um sistema estatal de educação, destinado a formar na cultura grega e na perícia militar macedónia os mais promissores dos jovens asiáticos. O nome dado a estes trinta mil paides não deixava de ser significativo: de facto, ao chamar-lhes epigonoi ('os descendentes' ou 'a nova geração') o soberano estava a assumir o projeto de fazer deles o sustentáculo da nova realidade política e militar, tornando-os capazes inclusive, em caso de necessidade, de substituir as falanges macedónias. ${ }^{33}$ Ora este ponto constituía, precisamente, uma nota de preocupação para os veteranos de Alexandre. Os primeiros sinais de descontentamento foram sentidos em vários quadrantes. Recorde-se, a título de exemplo, a morte intempestiva do seu amigo Clito, ${ }^{34}$ por ter-lhe atirado em público receios que eram partilhados por muitos outros concidadãos: o abandono das tradições macedónias; o autoritarismo crescente, que o afastava dos companheiros mais antigos; a pretensão de ser filho do deus Ámon e ainda a cedência ao ambiente interesseiro da corte. Foram motivos idênticos que levaram também alguns hetairoi e Calístenes em particular a opor-se à introdução da proskynesis. ${ }^{35}$

33 Por contraste e zombaria, os Macedónios denominavam aqueles jovens de 'bailadores de pírrica' (cf. Plutarco, Alex. 71.3).

34 Plutarco, Alex. 50-51; Arriano, 4.8.1-9.4; Cúrcio Rufo, 8.1.19-2.10. Esta morte deixaria Alexandre profundamente abalado, até porque ocorrera num momento em que o soberano perdera o controlo de si mesmo, num acesso de ira potenciado pelo desgaste dos combates e pelo abuso da bebida.

35 Plutarco, Alex. 54.2-55.4; Cúrcio Rufo, 8.5.5-6.1; Justino, 12.7.1-3. 
A crispação aumentou de tom quando, em fevereiro de 324, numa altura em que o exército ainda se encontrava estacionado em Susa, os epigonoi foram apresentados a Alexandre, com todo o garbo de quem tinha acabado de terminar os quatro anos de formação. Assim, quando no verão desse mesmo ano, em Ópis, Alexandre anunciou em assembleia a decisão de enviar para a Macedónia, depois de generosamente recompensados, os veteranos que já não estavam aptos para campanhas tão duras - em vez da esperada alegria gerou-se um motim. A desarticulação entre as expetativas de Alexandre e as dos Macedónios mostra que o soberano já não estava tão próximo como outrora dos seus soldados e que estes nutriam receios antigos relativamente à sua progressiva orientalização. A tensão acabou por ser resolvida habilmente pelo rei e cerca de dez mil veteranos tomariam o caminho de casa. Antes disso, porém, Alexandre não quis deixar de celebrar um grande banquete de reconciliação, onde estiveram presentes nove mil convidados, entre Macedónios, Gregos, Persas e representantes de outras etnias asiáticas.

Todo este episódio é narrado também por Plutarco, entre outras fontes, mas o relato de Arriano simboliza melhor o verdadeiro alcance da política de fusão étnica e cultural que estava na base da organização do banquete. Depois de os adivinhos gregos e de os magos persas haverem declarado os presságios favoráveis, Alexandre fez a seguinte prece (7.2.9): "pediu, em particular, pela concórdia (bomonoia) e pela partilha (koinonia) do poder entre Macedónios e Persas". ${ }^{36}$ Esta declaração foi depois secundada por uma libação geral e por uma canção de vitória entoada em uníssono, que marcavam simbolicamente o triunfo da política asiática de Alexandre: aos Europeus e aos Asiáticos cabia, agora, partilhar o governo e a administração de um território globalizado.

E assim, da experiência pan-helénica, que o levou, como hegemon da Hélade, até onde os Gregos nunca tinham antes chegado, Alexandre foi evoluindo para uma nova ideologia de fusão étnica e cultural, onde a homonoia e a koinonia eram o novo elo de ligação. A partir destes princípios, estavam lançadas as bases do cosmopolitismo e a experiência de globalização que haveriam de marcar a época helenística. É sobre as marcas dessa nova realidade política, cultural e económica que se falará nos próximos dois capítulos, a propósito da cidade de Alexandria e do julgamento de Paulo de Tarso (infra 7 e 8, respetivamente).

\footnotetext{
36 Sobre o significado destes eventos, vide Hammond (1997) 188-190.
} 


\section{ALEXANDRIA IDENTIDADE E COSMOPOLITISMO}

\subsection{O cânone das Sete Maravilhas da antiguidade: o farol de Alexandria ${ }^{1}$}

Qualquer reflexão sobre Alexandria não dispensa uma referência à figura carismática da pessoa que lançou as bases para a fundação de uma cidade que, tal como o seu mentor, viria a encarnar o espírito de toda uma nova época. E embora a atuação de Alexandre tenha constituído o assunto do capítulo anterior (supra 6), justifica-se ainda assim que seja retomada uma breve síntese dos principais aspetos ligados à sua existência, antes de se falar sobre a cidade que dele retira o nome.

\subsubsection{A imagem tutelar de Alexandre}

Se bem que tivesse vivido pouco mais de trinta anos (356-323) e governado menos de década e meia (336-323), Alexandre conseguiu a proeza de conquistar um império imenso, que ia desde a Europa até à Ásia, abrangendo também o nordeste africano e boa parte da bacia do Mediterrâneo. Dotado de uma genial capacidade militar e de invulgar sagacidade política, o jovem imperador rapidamente se transformou numa figura carismática, que os cronistas oficiais e o decurso do tempo se encarregariam de amplificar até às raias da divinização. Embora objetivamente excecionais, estas qualidades não o teriam furtado a

\footnotetext{
1 A parte relativa ao Farol de Alexandria recupera, no essencial, a argumentação exposta pelo autor em Leão \& Mantas (2009) 109-117.
} 
enfrentar duras provas para manter sob controlo o enorme império conquistado, como ilustram contrariedades e levantamentos com que teve de lidar dentro do próprio exército e que apenas a sua morte prematura impediu que ganhassem contornos mais sérios. Ainda assim, Alexandre marca o final de um período e lança, por certo, as fundações para a época helenística, um período muito rico do ponto de vista económico, científico e cultural. ${ }^{2}$

Ora a formação de um cânone de 'maravilhas' fabricadas pelo génio humano (thaumata) é indissociável tanto da figura de Alexandre como do mundo por ele criado. É certo que o gosto por viajar e conhecer outros costumes e culturas estava profundamente arreigado na mentalidade grega, conforme ilustra, de maneira paradigmática, a atuação de Ulisses na epopeia homérica, ao aliar a sua natureza inventiva (que justifica o epíteto de 'herói dos mil artifícios' - polymetis, polymechanos) a uma curiosidade inata por experimentar novos desafios, mesmo quando viesse a resultar deles um prejuízo pessoal (e daí que Ulisses seja também designado por polytlas - 'o que muito sofreu'). Aliás Heródoto, que viveu antes da existência da maioria das obras humanas que viriam a integrar o grupo das 'maravilhas', não deixou, em todo o caso, de assinalar já na sua obra o profundo respeito pela antiga Babilónia e pelo Egipto. De resto, o autor de Halicarnasso partilha com Ulisses o mesmo espírito agónico e indagador, que o levou a assinalar na sua obra as inúmeras impressões que recolheu ao longo das viagens realizadas. Ainda assim, o registo dessas informações resulta, em boa parte, de uma dinâmica que estimula a curiosidade pelo não-grego, pelo bárbaro, enquanto expressão de alteridade. Em contrapartida, um dos principais legados de Alexandre consiste, precisamente, em promover a substituição da tradicional oposição grego/bárbaro por uma prática política e social que promovia a fusão étnica e cultural (supra 6.4). Desta vocação cosmopolita, que marcará as grandes urbes helenísticas, resultará um natural estímulo à mobilidade de ideias, de pessoas e de bens. Por conseguinte, a formação de uma listagem de 'maravilhas' ou 'coisas que causam espanto' (thaumata) é indissociável da consciência de que há 'coisas que merecem ser vistas' (theamata) em paragens distantes, mas que integram igualmente esse novo mundo cada vez mais calcorreado por viajantes curiosos e ávidos de conhecimento. ${ }^{3}$

\footnotetext{
2 Para mais pormenores, vide supra 1.2.

3 Pertinentes as observações de Clayton \& Price (1988) 4-5.
} 


\subsubsection{Alexandria}

Apesar do trabalho feito em vida de Alexandre, a cristalização dos traços essenciais da sociedade helenística deve muito igualmente à ação dos Diádocos, os generais que serviram sob as suas ordens. De facto, com a morte de Alexandre e não havendo um sucessor natural, era uma questão de tempo até que o imenso império que conquistara se começasse a desintegrar. E embora, num primeiro momento, os Diádocos (generais que estiveram ao seu serviço) se tivessem comprometido a dividir a administração das províncias, enquanto aguardavam que o filho de Alexandre e Roxana chegasse à maioridade, na verdade acabaram por se envolver rapidamente em disputas de soberania que se prolongariam, com intensidade variada, durante décadas. Da inelutável divisão do império, resultaria a base das futuras realezas helenísticas, perante a inviabilidade de alguém conseguir ocupar o posto de governante único nas mesmas condições que Alexandre. Apareceram, desta forma, os grandes reinos do Egipto, Macedónia, Ásia e, em período posterior, o de Pérgamo. Embora a posição do rei fosse variando quanto à forma de exercer a soberania nestas monarquias hereditárias, na verdade este regime político acabava por ser a resposta possível à necessidade histórica de encontrar um poder central forte e estável que garantisse a coesão de territórios geograficamente extensos e divididos por grandes diferenças étnicas e culturais (supra 1.2.2).

Uma outra marca característica da época helenística e também da visão empreendedora de Alexandre diz respeito ao surgimento de novas cidades, que poderiam atingir centenas de milhares de habitantes - uma concentração demográfica que seria impensável para as póleis clássicas. Ora a mais emblemática dessas urbes cosmopolitas é seguramente Alexandria, que viria a substituir Mênfis como capital do reino do Egipto, sob o poder dos Ptolomeus. ${ }^{4}$ Esta dinastia foi iniciada por Ptolomeu, um dos chefes militares que mais se distinguiram ao serviço de Alexandre e também dos primeiros a compreender que era irrealista o projeto de tentar ocupar o posto do imperador. Em vez disso, optou por reforçar a estabilidade do reino do Egipto, um objetivo que passava também

\footnotetext{
$4 \mathrm{Na}$ antiguidade, foram fundadas dezassete Alexandrias, com idêntico objetivo de honrar o jovem macedónio. Esta, porém, construída segundo um plano de Dinócrates de Rodes, no Delta do Nilo, iria tornar-se na mais importante de todas, a ponto de este período se designar também frequentemente por época alexandrina.
} 
pelo interesse em legitimar o seu poder enquanto soberano, já que, além da força, Ptolomeu não possuía outra base segura para validar esse domínio. Ora a ligação a Alexandre e ao imaginário de sucesso que lhe andava associado servia na perfeição tal desiderato. Um dos primeiros sinais dessa estratégia encontra-se no facto de Ptolomeu ter literalmente raptado o corpo do imperador, quando estava de passagem pelo Egipto no processo de trasladação entre a Babilónia e a Macedónia. O féretro começou por ficar em Mênfis, mas quando a capital se mudou para Alexandria, o corpo seguiu o mesmo destino, sendo colocado num sarcófago de ouro.

Idêntica motivação poderá explicar, em parte, a criação de dois dos monumentos mais paradigmáticos da nova capital: o Museu (ou templo das Musas) e a Biblioteca. Embora os pormenores sobre a sua edificação sejam pouco abundantes e sujeitos a dúvidas, afigura-se provável que a decisão de os construir tenha cabido a Ptolomeu I, competindo ao filho (Ptolomeu II) a nobre tarefa de os expandir. Tanto o Museu como a Biblioteca representam, desde a antiguidade, a exemplificação prática do espírito cosmopolita das novas urbes helenísticas. A sua criação tem sido entendida como expressão do influxo peripatético sobre este período de ouro da ciência, ${ }^{6}$ mas enquadra-se também dentro da longa tradição de patrocínio cultural que remonta já às tiranias da época arcaica e clássica e que os novos monarcas procuram igualmente cultivar. Além disso, no caso dos Ptolomeus, estes monumentos contribuíam ainda para o objetivo de reforçar as conexões com Alexandre e de legitimar uma soberania de matriz grega (e por isso estrangeira) num contexto culturalmente tão exuberante como o do antigo Egipto. Ora é também com este cenário de fundo que se deve entender a importância da construção do Farol de Alexandria e respetiva inclusão no rol das Maravilhas da Antiguidade.

\subsubsection{A Torre de Faros}

O Farol de Alexandria, situado na costa noroeste do Delta do Egipto, foi a última das construções a integrar a lista das Sete Maravilhas. Ainda assim, não

\footnotetext{
5 E mais tarde substituído por um outro de vidro. Sobre esta estratégia de legitimação do poder e de engrandecimento seguida por Ptolomeu, vide Erskine (1995).

6 Na sequência, aliás, do magistério de Aristóteles sobre o jovem Alexandre.
} 
deixou de se destacar do conjunto destas criações humanas, e por um duplo motivo: antes de mais porque, entre os vários monumentos, era o que possuía claramente uma utilidade prática maior, ao servir de orientação para os navegantes; por outro lado, esta importante função fez com que o termo 'farol' se generalizasse para denominar os edifícios construídos para cumprir idêntico objetivo, à semelhança do que aconteceu com o Mausoléu de Halicarnasso.

No entanto, esta designação de 'farol' resulta de uma circunstância fortuita: do facto de a Torre em questão haver sido edificada em Faros, uma pequena ilha situada em frente do porto de Alexandria. O conhecimento desta ilhota era bastante antigo, pois Homero já se lhe refere, pela boca de Menelau, na Odisseia (4.354-360):

Ora existe uma ilha no meio do mar muito encrespado defronte do Egipto: chamam-lhe a ilha de Faros.

Dista do continente o que navegaria uma côncava nau num dia, quando tem por trás um vento guinchante.

Ali há um porto de bom ancoradouro, donde os homens lançam naus recurvas para o mar alto, depois de se terem abastecido de água negra?

Com esta breve nota, o poeta épico não deixa de registar, desde logo, a localização estratégica de Faros, que fornecia um bom ponto para se fazer escala, no meio da zona arenosa e de aluvião característica do Delta do Nilo ${ }^{8}$. Muitos séculos depois, mais concretamente em 332, na breve passagem que fez pelo Egipto, Alexandre iria registar igualmente as potencialidades do lugar, de forma que decidiu construir aí uma cidade, que fixaria para a posteridade o seu nome. Valerá a pena evocar a descrição que, cerca de trezentos anos mais tarde, Estrabão faz deste famoso centro urbanístico, em particular a parte em que se refere ao Farol (Geografia 17.1.6 e 9):

\footnotetext{
7 Tradução de Frederico Lourenço (2003).

8 Sobre a relação da ilhota com a passagem de Helena pelo Egipto, bem como sobre a confusão onomástica que levara Menelau a considerar que Faros era dedicada a Proteu, uma divindade com poderes proféticos, vide Clayton (1988) 138-139.
} 
O promontório extremo da ilhota de Faros é um rochedo batido pelo mar de todos os lados, sobre o qual fica uma Torre espectacular, construída em mármore branco, com vários andares, e que tem o mesmo nome da ilha. Foi erigida por Sóstrato de Cnidos, amigo dos reis, a pensar na segurança dos marinheiros, conforme atesta a inscrição. De facto, porque a costa não oferecia abrigo natural e era pouco elevada de ambos os lados, além de estar pejada de baixios e escolhos, tornava-se necessário facultar num sítio alto e bem visível um sinal claro que guiasse os marinheiros provenientes de alto mar, ajudando-os a encontrar a entrada do porto. A passagem que se encontra a ocidente também não é de entrada fácil, embora não exija tantas precauções. Forma também ela um outro porto, chamado Eunosto 9 e serve de enseada ao porto artificial fechado. Com efeito, o porto cuja entrada está dominada pela Torre de Faros, antes referida, trata-se do Grande Porto, sendo que aqueles dois se encontram unidos a este pelas profundezas, estando separados somente pelo molhe conhecido por Heptastádion ${ }^{10}$.

À direita da entrada do Grande Porto, encontra-se a ilha e a Torre de Faros; do outro lado, ficam os baixios e o promontório Lóquias, sobre o qual existe um palácio real. E à medida que se navega para dentro do porto, aparecem, à esquerda, os palácios reais interiores, que surgem na continuação do de Lóquias, e onde existem muitas construções decoradas com cores variegadas e pequenos bosques. Logo abaixo deles fica o porto artificial, oculto à vista, que serve para uso privativo dos reis. Encontra-se aí também Antirrodes, uma ilhota situada um pouco ao largo do porto artificial, que possui um palácio real e um pequeno porto. Dão-lhe este nome, como se fosse uma espécie de rival de Rodes.

Embora sem entrar nos pormenores técnicos ${ }^{11}$ relativos à natureza do Farol enquanto edifício, será vantajoso evocar, antes disso, alguns pormenores relacionados com a identificação da pessoa responsável pela construção e com a data em que fora levada a cabo - assuntos esses que continuam a suscitar certa discordância entre os estudiosos. A obra parece ter sido iniciada ainda no reinado de Ptolomeu I, possivelmente no ano de 297, se bem que o monarca talvez não fosse o responsável pelo lançamento da edificação. O nome de Sóstrato

\footnotetext{
9 À letra, 'porto do bom regresso'.

10 Designação derivada do facto de ter 'sete estádios' de comprimento.

11 Para uma análise dessas questões, vide Leão \& Mantas (2009) 117-125.
} 
de Cnidos aparece várias vezes aliado ao monumento, seja como arquiteto seja ainda como promotor da iniciativa ou doador do edifício. Isto mesmo se pode ler no testemunho de Estrabão, agora em análise, ao transmitir o que se afigura ser o texto da inscrição votiva: "Foi erigida por Sóstrato de Cnidos, amigo dos reis, a pensar na segurança dos marinheiros, conforme atesta a inscrição". Luciano de Samósata, que viveu no séc. II d.C., refere-se também à mesma dedicatória, em termos ligeiramente diferentes: "Sóstrato de Cnidos, filho de Dexífanes, aos deuses salvadores, em benefício dos que navegam pelo mar". O alcance da expressão "deuses salvadores" tem sido objeto de interpretações várias: poderá talvez referir-se aos soberanos egípcios, conforme parece sugerir Estrabão, na medida em que Ptolomeu I era conhecido pelo título de Soter ('salvador'), além de que tanto ele como a esposa Berenice são apelidados de 'deuses' em moedas emitidas pelo filho e sucessor, Ptolomeu II Filadelfo. Também tem sido aventada a hipótese dos Dioscuros (Castor e Pólux), que se tornaram patronos da navegação, bem como as figuras de Proteu, que era senhor da ilha de Faros, e de Zeus Soter, cuja estátua coroaria o topo do Torre ${ }^{13}$.

Do cotejo dos diferentes testemunhos, não será desajustado concluir que a Torre de Faros teria sido iniciada durante o reinado de Ptolomeu I e terminada no tempo de Ptolomeu II. Quanto a Sóstrato de Cnidos, mais do que o arquiteto, deverá identificar-se provavelmente com uma individualidade próxima dos soberanos (seja um membro da corte ou um comerciante), com riqueza suficiente para custear as despesas da obra que iria oferecer à cidade, dando assim outro notável contributo para o engrandecimento da mais paradigmática das urbes helenísticas.

Pese embora a importância destas emblemáticas construções, a cidade de Alexandria constituía também um notável mosaico étnico onde avultavam, em particular, três comunidades: a egípcia autóctone, a macedónia/grega (cultural e politicamente dominante) e a judaica. Se é certo que a autoridade do faraó servia de força aglutinadora essencial para garantir a união do conjunto, havia ainda assim um potencial de desagregação (ou ao menos de conflituosidade) igualmente

\footnotetext{
12 Sobre a forma de escrever história, 62

13 Esta última hipótese tem a favor dela o facto de Posidipo, um poeta contemporâneo da edificação do monumento, ter composto um epigrama para celebrar possivelmente a conclusão do edifício, no qual invoca Proteu e se refere também a Zeus Soter. Sobre a problemática ligada à interpretação destas e de outras fontes, vide Clayton 1988: 142-145.
} 
bastante acentuado, em especial da parte daqueles que eram mais zelosos das suas raízes religiosas e culturais, como acontecia com os Judeus. Importa, assim, refletir de seguida na forma como o cosmopolitismo característico do período helenístico e de Alexandria em particular terá convivido com as exigências de uma consciência identitária fortemente marcada.

\subsection{O politeuma judaico de Alexandria}

A notícia de contactos entre Gregos e Judeus remontará a um período bastante recuado no tempo, como se pode inferir a partir de nomes hebraicos (como Jafet e Javan) reminiscentes de nomes gregos míticos (Jápeto e Íon) e do facto de o próprio rei David ter recorrido, num período tão distante como o séc. x, a mercenários gregos oriundos de Creta. Por outro lado, foram também encontrados, na Samaria, vestígios de cerâmica que sugerem a existência de contactos comerciais com a Grécia já no séc. viı. O tradicional emblema ateniense da coruja encontra-se em moedas judaicas do séc. v e, durante a invasão persa, haveria mercenários judeus entre as fileiras persas que invadiram a Grécia, em 480, ao serviço de Xerxes. ${ }^{14}$ Uma das primeiras alusões significativas aos Judeus, na literatura grega, aparece numa breve referência nas Histórias de Heródoto (2.104.2-3), a propósito da prática da circuncisão, que os Sírios da Palestina (i.e. os Judeus) teriam aprendido com os Egípcios. ${ }^{15}$ Segundo Flávio Josefo (Contra Ápion, 1.176-182), Clearco de Solos, que fora discípulo de Aristóteles, narrava no livro primeiro da sua obra Sobre o sono que o mestre se teria encontrado com um judeu da Ásia Menor. O relato é geralmente considerado apócrifo, mas o facto de o peripatético Clearco entender que a notícia era digna de registo acaba por ser revelador da elevada opinião em que os Judeus eram tidos (tal como os Indianos) enquanto um povo talhado para a reflexão filosófica. Idêntica valoração positiva é feita por Teofrasto, que sucedeu a Aristóteles à frente do Liceu, e cujo testemunho (transmitido por Porfírio, Sobre a abstinência, 2.26)

14 Cf. Flávio Josefo, Contra Ápion, 1.172-173, que se baseia num poeta grego de nome Quérilo para essa informação. Vide Feldman \& Reinhold (1996) 1.

15 Para outros paralelismos entre o mundo semítico e a literatura grega, desde os Poemas Homéricos até Xenofonte, vide a detalhada sistematização de Rodrigues (2005). 
tem o inegável mérito de ser a mais antiga fonte, depois da Bíblia, a descrever as práticas sacrificiais judaicas. ${ }^{16}$ Porém, entre estes relatos mais recuados sobre os Judeus feitos por não-Judeus, o mais extenso deriva da obra História do Egipto de Hecateu de Abdera, num longo passo citado por Diodoro Sículo (Biblioteca Histórica, 40.3). Embora acolha alguns erros (como dizer que Moisés teria fundado Jerusalém e construído o Templo sagrado) e faça alguns remoques aos modos agrestes decorrentes da dura experiência do exílio, ${ }^{17}$ Hecateu acaba por dar uma imagem bastante positiva dos Judeus, com os quais talvez tenha entrado em contacto direto por alturas da sua visita ao Egipto.

Com a referência a Hecateu de Abdera (que viveu entre c. 360 e 290), entra-se igualmente no período compreendido entre as campanhas de Alexandre e os inícios do reinado dos Ptolomeus, fase que abre um novo e fulgurante capítulo na história dos Judeus, em especial no que diz respeito à sua fixação no Egipto. Flávio Josefo (Contra Ápion, 1.186-204) atribui a este mesmo Hecateu um tratado Sobre os Judeus, mas o seu autor deve ser, pelo contrário, um judeu, que teria composto esta obra à volta de meados do séc. II. ${ }^{18}$ Apesar destas limitações, um dos passos de Pseudo-Hecateu citados por Josefo é muito ilustrativo da importância que o respeito pelas regulamentações tradicionais tinha entre os Judeus - aspeto que Alexandre terá sabido respeitar, em linha aliás com o que fez com outros povos conquistados, como os próprios Persas. Será, por isso, pertinente evocar o episódio como forma de introduzir a questão dos privilégios que os Judeus teriam recebido ao deslocar-se para Alexandria: ${ }^{19}$

Com efeito, Hecateu demonstra, em outra ocasião, o respeito que temos em relação às leis (nomoi) e ainda que de bom grado nos parece bem tudo sofrer de forma a não as transgredirmos. "Como tal," — diz ele - embora sejam objeto do escárnio de povos vizinhos e de todos os visitantes estrangeiros, e sejam muitas vezes tratados com ignomínia pelos reis e sátrapas da Pérsia, ainda assim não

\footnotetext{
16 Embora registe vários erros de pormenor, como sustentar que os sacrifícios eram feitos durante a noite ou que seres humanos eram também usados como vítimas.

17 Cf. 40-3.4: "como resultado da sua própria expulsão [do Egipto, Moisés] introduziu um modo de vida associal e intolerante".

18 Para mais pormenores sobre a 'descoberta' dos Judeus por autores gregos, vide Feldman \& Reinhold (1996), 1-14, esp. 10 para o caso do Pseudo-Hecateu agora referido.

19 Flávio Josefo, Contra Ápion, 1.190-192.
} 
deixam que se abale a sua firme determinação. Pelo contrário, em defesa desses princípios, estão dispostos a ser despidos e a enfrentar torturas e mortes terríveis, mais do que todos os outros, só para não renunciar aos costumes dos seus antepassados (ta patria).” De resto, ele faculta não poucos testemunhos desta obstinada defesa das suas leis (nomoi). Refere, com efeito, aquela altura em que Alexandre se encontrava na Babilónia e decidiu recuperar o templo arruinado de Bel, ordenando a todos os soldados, sem distinção, que carregassem material para as obras. Apenas os Judeus se recusaram a obedecer, mesmo sendo submetidos a duras punições e ao pagamento de pesadas multas, até que o rei lhes perdoou a denega e os isentou da tarefa.

A presença de contingentes judeus entre as tropas de Alexandre não suscita grande surpresa, pois, como atrás se viu, já no séc. v se podiam encontrar mercenários com essa origem entre as fileiras do exército persa. ${ }^{20}$ Por outro lado, a ideia de o líder macedónio mostrar alguma compreensão relativamente às interdições ditadas pelas leis judaicas (mesmo com o aparente risco de perda de autoridade ${ }^{21}$ ) não deixa de encontrar paralelo na forma como Alexandre soube respeitar os inimigos vencidos, fosse por efetiva convicção ou por simples pragmatismo político, como aconteceu ao adotar aspetos do protocolo persa, mesmo perante a incompreensão dos seus companheiros de armas. ${ }^{22}$ Não sendo improvável do ponto de vista histórico, este pormenor juntava-se a uma série de muitos outros que faziam de Alexandre um grande benfeitor da identidade judaica - facto que as fontes tendem a justificar com uma provável intervenção divina. Com efeito, a primeira visita de Alexandre a Jerusalém (em 332), fora precedida, segundo a tradição, de uma enorme tensão, porquanto o sumo-sacerdote

20 Hengel (1989), 187 e n. 1, diz que não há razões para duvidar de que mercenários judeus terão servido sob as ordens de Alexandre, embora considere sem valor histórico a tradição de que o monarca macedónio teria concedido isopoliteia ('igualdade de direitos políticos') aos militares judeus que se fixaram em Alexandria.

${ }^{21}$ Mason (2007), 112 n. 650, considera que esta punição de soldados que desobedeceram a ordens diretas parece ser "unnaturally light".

22 É particularmente significativo o ritual de proskynesis ('prostração'), que Alexandre passou a exigir como sinal de deferência à sua pessoa, mas que os Gregos consideravam um indício de perigosa megalomania. Sobre a forma como Alexandre evoluiu da imagem de chefe de uma coligação pan-helénica contra o Bárbaro para uma estratégia de inclusão dos vencidos na nova ordem governativa, vide supra 6.4 . 
recusara, num posicionamento inicial, trocar a fidelidade ao rei persa Dario pelo entendimento com os Macedónios, facto que os levaria a avançar contra Jerusalém.

O vívido relato destes acontecimentos é feito por Flávio Josefo, nas Antiguidades Judaicas (11.304-346), em termos cuja historicidade é, no mínimo, altamente suspeita. Com efeito, a epifania experimentada por Alexandre em Jerusalém tem demasiados pontos de contacto com uma outra, vivida um ano mais tarde, para ser simples coincidência. Trata-se da famosa peregrinação ao templo de Ámon no oásis de Siwah, na Líbia, realizada numa altura em que o general havia já escolhido o local onde implantaria a nova capital do Egipto. ${ }^{23}$ Vários pormenores referidos quando da visita de Alexandre ao templo de Jerusalém - como o facto de trazerem diante dele o Livro de Daniel (que na realidade fora escrito no final da primeira metade do séc. II), onde se anunciava que um grego destruiria o império persa - indiciam que o episódio reflete provavelmente uma tradição judaica posterior onde se detetam as mesmas marcas de amplificação lendária respeitantes aos feitos do chefe macedónio, já anteriormente analisadas (supra 6.1). Ainda assim, continua a ser pertinente evocar, para os objetivos deste estudo, a parte final do relato de Josefo, em que são referidos os privilégios que teriam sido outorgados por Alexandre aos Judeus: ${ }^{24}$

No dia seguinte, mandou chamar de novo [os Judeus] e instou-os a que lhe pedissem os favores que desejassem. O sumo-sacerdote pediu o direito de se poderem reger pelas suas leis ancestrais (patrioi nomoi) e ainda que o sétimo ano ${ }^{25}$ ficasse isento de tributo, e [Alexandre] em tudo anuiu. Solicitaram-lhe ainda que fosse concedido aos Judeus da Babilónia e da Média o direito de se regerem pelas próprias leis (idioi nomoi), e ele prometeu de boa mente cumprir esses desejos. Depois, disse ao povo que, se alguns deles quisessem juntar-se ao seu exército, conservando embora os costumes ancestrais (ethe patria) e vivendo de acordo com eles, Alexandre estaria na disposição de os levar consigo. Muitos foram os que aceitaram de bom grado servir sob as suas ordens.

23 Para uma análise do relato de Flávio Josefo, na parte respeitante à viagem a Jerusalém, em articulação com a visita ao templo de Ámon, vide Modrzejewski (1995) 50-55.

24 Flávio Josefo, Antiguidades Judaicas, 11.337-339.

25 Trata-se do 'ano sabático' (Levítico, 25.2), que obrigava a que, de sete em sete anos, a terra fosse deixada em descanso, em honra do Senhor. 
À parte o problema da exatidão histórica deste relato, que faz recuar ao tempo de Alexandre decisões que, na verdade, serão bastante posteriores, ${ }^{26} \mathrm{a}$ essência do significado político e ideológico destas medidas não deixa de ser válida. Com efeito, numa perspetiva política, o relato mostra que a Judeia manteve, na época helenística, um estatuto semelhante ao que tivera sob domínio persa: a capacidade para se afirmar como entidade étnica e religiosa, organizada à volta do poder sacerdotal, cujo centro era o Templo de Jerusalém. Já de um ponto de vista ideológico, o relato exemplifica as bases do relacionamento que se viria a estabelecer entre os soberanos helenísticos e os Judeus: os primeiros distribuíam benefícios e aceitavam respeitar a lei mosaica, enquanto os segundos garantiam a fidelidade ao monarca e a disponibilidade para combaterem sob as suas ordens. Havia, no entanto, uma alteração importante no que se referia à natureza legal intrínseca da Torá: no passado, funcionara para os Judeus como uma lei emitida pelo poder central, vinculativa por si mesma; agora, porém, era apresentada como 'lei ancestral' (patrios nomos) dos Judeus, cuja validade tinha no entanto de ser confirmada pelos novos governantes. Desta forma, a Torá acabava por aproximar-se do estatuto jurídico dos patrioi nomoi usados pelos Gregos das cidades asiáticas que Alexandre libertou do domínio persa. ${ }^{27}$ Ora é sobre este paralelismo entre a situação legal dos Judeus e dos Gregos que importa refletir mais detidamente, a propósito da natureza do politeuma judaico de Alexandria, que constitui um elucidativo exemplo da forma como os Judeus da diáspora se poderiam organizar em comunidades estáveis, do ponto de vista social, político e legal.

Segundo Pseudo-Hecateu, ${ }^{28}$ pouco depois da batalha de Gaza (312), os judeus que vieram para o Egipto na sequência da conquista macedónia trouxeram consigo um exemplar da Torá. Ezequias, o sumo-sacerdote que os acompanhava a partir da Judeia, reuniu um grupo de amigos, eventualmente durante o Sabbath, e leu-lhes todo o texto, em hebraico, no qual, segundo o testemunho de Pseudo-Hecateu, "estava escrita a história do seu estabelecimento na terra (katoikesis) e

26 Modrzejewski (1995), 55, diz que Flávio Josefo está simplesmente a antecipar em cerca de 130 anos as medidas levadas a cabo por Antíoco III, quando, por volta do ano 200, definiu o estatuto de Jerusalém dentro do império selêucida.

27 Sobre o surgimento do tema da patrios politeia (e dos patrioi nomo $i$ ) na propaganda política ateniense de finais do séc. v, vide supra 3.3.

28 Citado por Flávio Josefo, Contra Ápion, 1.186-189. 
da constituição do estado (politeia gegrammene)" ${ }^{29}$ Esta informação é um pouco ambivalente, pois não fica totalmente claro pelo contexto se os termos katoikesis e politeia dizem respeito à história passada dos Judeus ou se ao momento em que este grupo se havia fixado em Alexandria. ${ }^{30}$

No entanto, no que diz respeito à Torá, cedo a comunidade judaica sentiu a necessidade de possuir uma versão em grego do texto sagrado, talvez em virtude de o processo de helenização ser tão acelerado que, decorridas algumas décadas sobre a fixação na capital helenística, a maioria dos Judeus talvez já não fosse capaz de entender o hebraico. Esta primeira versão da Torá para grego é a famosa tradução dos Septuaginta e não cabe agora discutir em pormenor as circunstâncias ligadas à forma como terá sido realizada. Para os objetivos deste estudo, basta sublinhar tanto a hipótese já avançada (de que a urgência de uma tradução decorrera da insuficiente perícia linguística em hebraico dos Judeus que frequentavam a sinagoga em Alexandria) ou aceitar a tradição de que teria sido o sucessor de Ptolomeu I Soter (portanto Ptolomeu II Filadelfo) quem, por volta do ano 270, teria decidido mandar traduzir a Torá (Pentateuco) para grego, de maneira a enriquecer os fundos da biblioteca de Alexandria. ${ }^{31}$ A superintendência dessa tarefa teria ficado a cargo do antigo estadista ateniense, Demétrio de Fáleron. ${ }^{32}$ Não é improvável que ambas as razões tenham tido o seu peso, e portanto que o desejo do monarca de valorizar a biblioteca (e de conhecer melhor um texto a que uma parte dos seus súbditos atribuía uma importância capital) tenha ido ao encontro de uma necessidade prática da comunidade judaica.

29 Flávio Josefo, Contra Ápion, 1.189. Sobre a interpretação deste passo e a ligação com a tradução dos Septuaginta, vide Modrzejewski (1995) 99-104.

30 Hengel (1989), 192-193, mostra-se também ambivalente na forma de entender esta politeia gegrammene, que tende a identificar com um decreto real que permitiria aos Judeus estabelecer-se em Alexandria com o estatuto especial de minoria étnica. No entanto, a indicação de que o texto fora lido no original (hebraico) sugere, pelo contrário, que se trata da Torá e que a politeia em causa dizia respeito à constituição da nação judaica. Por outro lado, a ideia, transmitida no mesmo passo, de que Ezequias "manteve estreitas relações connosco" pode ser uma indicação de que o sumo-sacerdote se dava bem com os Gregos e estava familiarizado com os seus costumes. Hegermann (1989), 160 e n. 3, afirma no entanto sem reservas que o passo implica a referência a um tipo de "short royal decree, the contents of which would be comparable to the letter from Antiochus III to Zeuxis", e no qual se explicitariam as condições para a fixação dos Judeus e se passava a escrito a sua constituição política.

31 Vide Feldman \& Reinhold (1996) 17-22, esp. 18-19.

32 Como salienta Modrzejewski (1995), 100, essa atribuição a Demétrio é um tanto suspeita, atendendo ao facto de que o bibliotecário servira já no tempo de Ptolomeu I e que favorecera a ideia de que fosse o irmão de Filadelfo a herdar o trono, de forma que viria a cair em desgraça a partir do momento em que foi este último quem acedeu ao poder. 
Esta tradição vem, de facto, registada num documento conhecido por Carta a Arísteas, teoricamente escrita por um elemento da corte real, mas que deve ter sido antes composta por um judeu. Segundo esse testemunho, a comunidade judaica e o próprio rei teriam ficado tão satisfeitos com o resultado obtido na tradução, que o texto assumiria a partir daí um estatuto de referência. Neste momento, mais do que as questões exegéticas à volta da Bíblia dos Septuaginta, interessa em particular a reação dos Judeus e a forma como a mesma comunidade judaica é apresentada, usando como guia para essa análise a paráfrase que Flávio Josefo faz da Carta a Arísteas: ${ }^{33}$

Uma vez transcrita a lei (nomos) e levado a termo o trabalho de interpretação, num período de setenta e dois dias, Demétrio reuniu todos os Judeus no local onde as leis (nomoi) haviam sido vertidas e procedeu à sua leitura, na presença dos próprios intérpretes. O povo aplaudiu sem reservas o trabalho dos anciãos que haviam traduzido a lei (nomos), louvou igualmente Demétrio por ter tido esta ideia, que lhes trouxera tão grandes benefícios, e solicitou ainda que dessem a lei (nomos) a ler também aos seus governantes. E todos eles — o sacerdote, os mais velhos entre os intérpretes e os chefes (proestekotes) da comunidade (politeuma) insistiram em que, tendo a interpretação sido levada a cabo de forma tão perfeita, fosse mantida no estado em que se encontrava e não sofresse nenhuma alteração.

Do ponto de vista político e legal, o texto comporta algumas informações preciosas. A natureza jurídica da Torá é insistentemente sublinhada pelos termos usados em grego para a referir (nomos/nomoi); por outro lado, à comunidade dá-se a designação de politeuma. Atrás, ao referir-se o texto de Pseudo-Hecateu sobre a vinda de Ezequias para Alexandria, fora usado o termo katoikesis, que, juntamente com a variante katoikia, é a palavra normalmente utilizada para designar uma colónia de estrangeiros em determinada localidade. ${ }^{34}$ Este tipo de organizações

33 Antiguidades Judaicas, 12.107-108.

34 Sobre a terminologia usada nas fontes para designar estas comunidades relativamente autónomas, vide Hegermann (1989), 158-161, cujas posições são adotadas neste ponto. Sobre o uso do termo politeuma na teorização política, já desde o tempo de Aristóteles e de Isócrates, mas com particular incidência durante a época helenística, vide Gambetti (2009) 43-52. A mesma autora salienta (pp. 48-49) que o politeuma judaico de Alexandria tinha seguramente uma origem militar e que essa circunstância poderia ter dado aos membros do politeuma um estatuto distinto e superior em relação à restante comunidade judaica, que constituiria o plethos ou 'multidão' em sentido mais lato. 
implicava alguma capacidade de autogoverno, mas não necessariamente direitos cívicos próprios de uma cidade. ${ }^{35}$ No caso concreto de politeuma, trata-se de um termo que pode ser usado para referir, genericamente, um qualquer assentamento urbano e os seus habitantes, mas que designa mais em particular uma comunidade de estrangeiros (embora não especificamente Judeus) com privilégios de certa forma comparáveis a direitos cívicos. Um outro aspeto importante é que esses grupos étnicos se caracterizavam por possuir também uma forte identidade religiosa.

Para proceder ao estabelecimento de politeumata e de katoikiai seria por certo necessária permissão oficial. Talvez a politeia gegrammene mencionada por Pseudo-Hecateu a propósito de Ezequias possa corresponder a esse documento fundacional, se bem que a interpretação do passo não esteja isenta de dificuldades, como atrás se viu. Por outro lado, embora a tradição das benesses que Alexandre teria dado aos Judeus seja um tanto idealizada e, em parte, anacrónica, pode ainda assim refletir a essência das condições concedidas: ${ }^{36}$ o direito de os colonos poderem viver de acordo com as suas leis tradicionais (patrio $i$ nomoi, idioi nomoi, ethe patria) e de aplicarem essas mesmas leis dentro da comunidade que a elas voluntariamente se vinculara - desde que isso não entrasse em confronto com a autoridade real. E embora não deva ser incluído entre essas concessões o direito à cidadania plena (como acontecia com a comunidade grega e macedónia), tratava-se sem dúvida de uma forma inteligente de o monarca promover a mobilidade de pessoas e de atrair populações empreendedoras, além de que favorecia também a paz social, já que os politeumata como o existente em Alexandria tinham capacidade para designar magistrados e criar a sua própria rede de tribunais e escolas, onde seriam aplicados os ensinamentos e determinações previstos na lei mosaica. ${ }^{37}$ Isso mesmo se encontra, de resto, bem sublinhado num passo de Flávio Josefo: ${ }^{38}$

\footnotetext{
35 Se bem que por vezes os politeumata pudessem evoluir para cidades. Havia outros termos para designar as comunidades de estrangeiros, como laos, synodos e synagoge (embora estes dois últimos pertençam a um período mais tardio).

36 Vide supra comentário a Flávio Josefo, Antiguidades Judaicas, 11.337-339.

37 Hegermann (1989), 161, aceita que alguns colonos judeus pudessem, a título individual, ter obtido a cidadania plena, mas sustenta (como aliás a generalidade dos estudiosos) que os Judeus enquanto comunidade nunca obtiveram esse direito, situação que aliás acabaria por criar enormes tensões com a comunidade grega, quando, em tempos romanos, Augusto veio a introduzir impostos para todos os não-cidadãos. Augusto reduziria também os direitos do politeuma judaico de Alexandria. Vide Rodrigues (2007) 337.
}

38 Antiguidades Judaicas, 14.117. 
Foi-lhes também estabelecido um governante (ethnarches), que governa a comunidade (ethnos), arbitra os julgamentos (kriseis) e supervisiona a implementação dos contratos (symbolaia) e das ordenações (prostagmata), como se fora um magistrado (archon) de um estado autónomo (politeia autoteles).

Tratava-se, portanto, inicialmente, de uma estrutura quase monárquica, que talvez não tenha durado muito tempo, pois na paráfrase da Carta a Arísteas, antes transcrita, fala-se de um grupo de chefes (proestekotes) da comunidade, e não de uma só pessoa que em si concentrasse o governo do politeuma.

Não é improvável, também, que a orgânica governativa do politeuma acusasse também uma crescente influência grega, como acontecera com a língua e, de resto, com alguns exemplos práticos de julgamentos envolvendo litigantes judeus e juízes gregos. ${ }^{39}$ Com efeito, embora por uma via bastante diversa, os Gregos de Alexandria e de outras urbes helenísticas haviam também chegado a um conjunto de regulamentações entendidas como 'leis comuns' ou 'leis civis' (politikoi nomoi) que remetiam não para um texto arquetípico (como acontecia com a Torá judaica), mas antes para a tradição das várias póleis, que dava forma a uma estrutura de jurisprudência globalmente identificada com a experiência jurídica grega. O reconhecimento da validade legal destas determinações tradicionais (que caem dentro do conceito lato de patrioi nomoi) acabou por ser uma das soluções mais eficazes encontradas pelos Ptolomeus para atrair ao Egipto muitos estrangeiros e estimular a mobilidade sem pôr em causa a paz social e a autoridade do monarca. Com efeito, aos vários nomoi egípcios, gregos e judeus (entre outros), aos quais era formalmente reconhecida capacidade de vinculação legal, sobrepunha-se a autoridade do monarca, que continuava a ter a última palavra através das suas regulações (diagrammata) e ordenações (prostagmata). Mas tal como os politikoi nomoi facultavam, à comunidade grega, a base jurídica para a organização política e para a gestão de conflitos, também a Torá viera cumprir o mesmo objetivo no que diz respeito ao politeuma judaico, razão pela qual a versão dos Septuaginta se revelara tão essencial.

\footnotetext{
39 É o caso de certo Dosíteo, um judeu de origem egípcia, que processou uma mulher judia, sendo o caso julgado no tribunal de Crocodilópolis, por um grupo de juízes gregos. Sobre este caso, vide Modrzejewski (1995) 108-109.
} 
Com o decurso do tempo, é natural que começasse a despontar, a partir desta confluência de tradições políticas várias, um substrato legal comum, comparável portanto na sua génese e objetivos ao processo verificado em outros domínios característicos deste período. Assim, a uma koine linguística e cultural, a época helenística (e em especial Alexandria) favoreceu também a eclosão de uma koine legal, igualmente responsável pelo sucesso do governos dos Ptolomeus. ${ }^{40}$ Era assim encontrada uma forma hábil de articular o cosmopolitismo decorrente da nova realidade política e social, com a necessária manutenção de uma matriz identitária forte e coesa, reservando um espaço de afirmação individual num universo marcado pela confluência aglutinadora de múltiplas sensibilidades. Esta capacidade para se inserir num universo profundamente multicultural, sem prescindir, no entanto, de afirmar a própria identidade étnica, tradição política ou religiosa, irá manter-se depois da dominação romana, como nos mostra o revelador exemplo de Paulo de Tarso, ao qual se vai dedicar o último capítulo deste livro.

40 Sobre os contornos desta koine legal, vide observações de Modrzejewski (1995) 107-112. 
(Página deixada propositadamente em branco) 


\section{PAUlo de TARSO E A JUSTIÇA dOS HOMENS HELENISMO E IMPIEDADE RELIGIOSA NOS ATOS DOS APÓSTOLOS}

\subsection{O cosmopolitismo de Paulo}

O empenho e espírito de entrega das primeiras comunidades cristãs bem como o acompanhamento das deambulações missionárias dos anunciadores da boa nova de Jesus Cristo fazem com que o livro dos Atos dos Apóstolos represente, além de um importantíssimo escrito doutrinário e um notável testemunho de fé, também um revelador documento de época. Os Atos dos Apóstolos estão permeados de situações que se traduzem em verdadeiros motivos recorrentes (na sequência aliás do que seria de esperar do assunto da narrativa), como aclamações, discursos inflamados de apoio ou de repúdio, perseguições, preces e também acusações várias, que por vezes desembocam em ordem de prisão e em processos formais. O facto de estes eventos acontecerem num amplo espaço geográfico sob domínio romano leva a que certos aspetos do procedimento legal tivessem de ser globalmente respeitados, como acontecia com a disposição prevista na Lex Porcia que proibia que um cidadão romano fosse flagelado em público, ainda por cima sem julgamento. Os efeitos práticos provocados pelo receio de desrespeitar esta lei são várias vezes explorados por Paulo, ao revelar de improviso que era cidadão romano, seja em Filipos (16.35-39) seja em Jerusalém (22.23-29), onde insiste aliás que obtivera esse direito por nascimento (i.e. por herança de um antepassado seu) e não por compra, como acontecia com o tribuno que o mandara algemar (22.28), o que vem de resto aumentar ainda mais o seu desconforto e receio. ${ }^{1}$ A cidadania

1 Cf. ainda 23.27. 
romana permitia-lhe, por conseguinte, ficar sob a proteção das autoridades imperiais romanas e apelar inclusive ao julgamento do imperador, que funcionava como tribunal de recurso de última instância para os cidadãos das províncias que achassem estar a ser injustiçados pelas autoridades locais. ${ }^{2}$

Por outro lado, as viagens de Paulo, que o levam desde Jerusalém até Roma, depois de percorrer regiões asiáticas e gregas, criam condições para identificar, no seu discurso e atuação, a confluência de múltiplas sensibilidades, em relação às quais o cristianismo nascente vem trazer perturbadoras novidades. E se isso justifica plenamente que Paulo, proveniente de Tarso, possa ser considerado (enquanto grego, romano, judeu e cristão) um verdadeiro kosmopolites do ponto de vista da experiência religiosa, política e legal, também ajuda a entender parte das estratégias de argumentação que, muito habilmente, ele soube produzir e adaptar, segundo o auditório formal ou de ocasião que escutava as suas palavras. Esta realidade faz com que as potencialidades de interpretação decorrentes da existência de Paulo sejam muito ricas, mas também dificulta grandemente a identificação exata do substrato histórico e cultural que pode estar por detrás de algumas das situações evocadas pelo autor dos Atos dos Apóstolos. Para minorar os riscos de uma operação que procure examinar o fundo legal subjacente aos percalços vividos por Paulo, a análise agora proposta vai centrar-se unicamente nos eventos que ocorreram em espaço helénico e, destes, irá ser explorada em particular a acusação e a ordem de prisão que Paulo e Silas tiveram de enfrentar, em Filipos, depois de o apóstolo ter exorcizado uma escrava que se dedicava à adivinhação (16.16-40). Será defendido que os termos da acusação sugerem, na essência, uma proximidade com os processos de impiedade religiosa (asebeia) que marcaram Atenas na viragem do séc. v para o séc. Iv a.C. E embora a experiência de Paulo ocorra já na segunda metade do séc. I da era cristã, não deixa ainda assim de afigurar-se legítimo fazer essa aproximação, num espaço herdeiro dos reinos helenísticos, cuja matriz cultural e linguística continuava a ter um reconhecido influxo de origem ática. A análise será iniciada, portanto, pela enunciação das linhas gerais que caracterizam o primeiro termo de comparação:

\footnotetext{
2 Alexander (2001) 1057-1058. Aliás, tanto Festo como Agripa reconhecem a inocência de Paulo, mas como este houvera apelado ao imperador, deveria, em consequência, ser enviado para Roma (26.32). Em vez de ser vista como uma contrariedade processual, a ida para Roma é interpretada como sendo a concretização de um projeto apostólico prévio (19.21) e ainda a realização da vontade divina (23.11).
} 
a especificidade da religião grega, a forma como a asebeia se manifestava e a tipologia de faltas e penalizações a que poderia dar origem. Feito esse enquadramento inicial, será depois altura de ponderar mais em particular a acusação enfrentada pelo apóstolo de Cristo em Filipos.

\subsection{Peculiaridades da religião grega antiga}

A religião grega estava intimamente relacionada com a comunidade, a ponto de ser próprio de cada pólis ter a sua divindade protetora, a qual constituía um traço distintivo da cidade, à semelhança do que se passava com a constituição, o dialeto ou a moeda nela cunhada. ${ }^{3}$ No entanto, a identidade da Hélade afirmava-se também pelo facto de as diferentes cidades-estado partilharem determinado sistema de valores, onde a religião assumia um papel importante. Assim, ser grego implicava igualmente, em termos latos, crer numa conceção politeísta da divindade, onde o correto desempenho de certas práticas rituais era a face mais visível das diligências necessárias para garantir o favor dos deuses. Por outro lado, na Grécia antiga não existia nada de comparável ao que a Bíblia significa para os Cristãos, nem uma casta sacerdotal propriamente dita, que tivesse a seu cargo o ofício religioso e a orientação espiritual. É certo que determinado tipo de cultos se encontrava, tradicionalmente, nas mãos de algumas famílias aristocráticas, como os Eumólpidas e os Cerices em relação aos Mistérios de Elêusis. Ainda assim, era mais característico do fenómeno religioso na Grécia que as manifestações públicas de honra aos deuses fizessem parte das funções normais dos magistrados, a par de outras responsabilidades cívicas. Daqui resulta a vertente marcadamente ritual e legalista da religião grega e até, de alguma forma, o seu pendor contratual: ao cumprir os preceitos, o crente espera obter a correspondente proteção divina. ${ }^{4} \mathrm{O}$ maior representante do legalismo era o oráculo de Apolo em Delfos, cuja importância ultrapassava a ação das diferentes

\footnotetext{
3 Nesta secção, usa-se, com adaptações e acrescentos, parte da informação apresentada em Leão (2004), esp. 201-205.

4 Visível, por exemplo, na oração formal feita por Crises a Apolo, como vem apresentada em Homero (Il. 1.33-42), onde o sacerdote recorda ao deus os serviços prestados. Em todo o caso, já na mesma epopeia se notam marcas de uma devoção mais sincera e dedicada, como quando Aquiles roga a Zeus que garanta o regresso a salvo do seu amigo Pátroclo (Il. 16.231-248).
} 
divindades próprias de cada pólis e dos cultos locais, afirmando-se assim como uma das mais expressivas manifestações de pan-helenismo, já desde as épocas arcaica e clássica.

No entanto, a Grécia conhecia ainda, no plano geral, uma outra grande tendência religiosa, que pressupunha uma iniciação e, por conseguinte, um maior envolvimento pessoal: as correntes mistéricas. Já acima se fazia alusão aos Mistérios de Elêusis, que são talvez o caso mais significativo, sobretudo atendendo ao facto de que este culto conjugava a celebração ligada a um santuário local com uma importância e projeção que ultrapassavam as fronteiras da Hélade. ${ }^{6}$

\subsubsection{Definição de asebeia}

Esta breve abordagem preliminar do fenómeno religioso entre os Gregos visava apenas evocar alguns dados necessários à definição daquilo que poderá constituir uma ofensa aos deuses, ou seja, um ato de asebeia. Contudo, a delimitação do conceito de asebeia, a que geralmente se dá o equivalente moderno de 'impiedade', tem-se revelado um tópico difícil. De facto, na linguagem comum o termo é com frequência usado de forma vaga, para designar a omissão de certas práticas. Um passo de Platão (Êutifron, 7a) poderá fornecer um elucidativo exemplo daquilo que o Gregos, através das palavras de Sócrates, consideravam ser uma falta em matéria religiosa:

A coisa e a pessoa que agradarem aos deuses (theophiles) serão piedosas (bosios); a coisa e a pessoa que lhes forem detestáveis (theomises) serão impiedosas (anosios). E estas duas realidades não são idênticas, pois o piedoso (hosios) e o impiedoso (anosios) constituem o exato oposto um do outro.

Embora o paralelo não seja total, já que o filósofo está a explorar as implicações semânticas do binómio hosios/anosios (que também pode ser entendido

\footnotetext{
5 Conforme deixa bem patente o impressionante testemunho de Platão, $R$. 427b-c.

6 Sobre o sacrilégio que, no ano de 415 a.C., envolveu a representação paródica destes Mistérios, levada a cabo em lugar impróprio e por indivíduos que não estavam habilitados para o efeito, vide Leão (2004), 214-220, e supra 3.3.
} 
como 'santo, devoto, legítimo' vs 'irreligioso, profano, ilegítimo') e não propriamente do termo asebeia, o texto citado não deixa de sublinhar que a noção de 'impiedade' estabelece uma relação direta com a natureza da atenção e deferência dispensadas à divindade, no sentido de cumprir ou não o que agradaria aos deuses. ${ }^{7}$ Contudo, outras ocorrências mostram que o conceito poderia ser mais abrangente. Assim acontece, por exemplo, com o pequeno tratado Sobre as Virtudes e os Vicios, que circula no corpus atribuído a Aristóteles. Ainda que o opúsculo seja quase certamente espúrio, isso não invalida a pertinência das afirmações que nele são feitas (1251a30-1251b2):

Há três formas de comportamento incorreto (adikia): a impiedade (asebeia), a avidez (pleonexia) e a insolência (bybris). A impiedade (asebeia) consiste em ter um mau procedimento para com os deuses (theoi) e génios divinos (daimones), para com os mortos, os pais e a pátria; a avidez (pleonexia) consiste em desrespeitar os contratos (symbolaia), tomando em disputa o que é contrário ao merecimento; a insolência (bybris) consiste na conduta que leva a buscar o próprio prazer à custa da desgraça alheia. [...] É portanto característico do comportamento incorreto (adikia) desrespeitar os costumes e preceitos ancestrais (ta patria ethe kai ta nomima), desobedecer às leis (nomoi) e aos governantes (archontes), enganar, cometer perjúrio, desrespeitar os acordos (bomologiai) e as garantias dadas (pisteis).

Este testemunho é bastante curioso, pois a asebeia vem apresentada como uma forma de conduta incorreta (adikia), a par de outras expressões de injustiça como a avidez (pleonexia) e a insolência (bybris). Não obstante a aproximação sugerida para os três conceitos enquanto expressão de uma realidade mais ampla e a ambiguidade relativa da última frase (que não esclarece de forma inequívoca qual a falta correspondente a cada um dos tipos de incorreção definidos na primeira parte do texto), é ainda assim legítimo deduzir que a asebeia

\footnotetext{
7 Num outro passo, Platão (Prt. 325c-326d) volta a recorrer ao mesmo binómio bosios/anosios num contexto em que está a falar sobre as características da educação antiga, em especial daquela fase em que a formação dos jovens depende dos ensinamentos que lhes são ministrados informalmente, em casa, desde tenra idade. O binómio é completado por outros pares de conceitos opostos (dikaion) adikon, kalon/aischron), cuja correta apreensão faz parte do aperfeiçoamento do carácter da criança. Sugere-se, assim, de forma clara, que a noção sobre o que seria 'piedoso' ou 'impiedoso' correspondia a uma forma de consciência quase intuitiva, quando a pessoa atingisse finalmente o estado adulto.
} 
se aplicava a afrontas cometidas contra os deuses, os mortos, os progenitores e a pátria — instâncias e entidades que se encontram precisamente protegidas por 'costumes e preceitos ancestrais' (ta patria ethe kai ta nomima), cuja origem se perde na raiz dos tempos e por isso tendem a ser considerados sagrados. ${ }^{8}$ Se for feito o cruzamento da informação veiculada por ambos os textos aduzidos, chega-se de alguma forma à noção de que a asebeia é a expressão de um comportamento reprovável à luz da moral divina e social, por constituir uma afronta em domínios que são determinantes para assegurarem estabilidade na existência humana e na vida em comunidade: a proteção dos deuses, a hierarquia familiar (bem como a sua memória) e a consciência de uma identidade política solidária.

Aceitando, como ponto de partida, esta definição genérica de asebeia, importa agora avançar para o problema da incidência jurídica do conceito. Há uma série de crimes onde é previsível a sobreposição entre o uso da linguagem comum e a aplicação legal do termo asebeia. Nesse rol se podem incluir delitos como a profanação de mistérios, realização imprópria de sacrifícios, violação de proibições rituais ou de interdições relativas à frequência de locais sagrados, saque de templos, desrespeito pelos suplicantes, mutilação de objetos sagrados. . Contudo, não é improvável que alguns destes crimes fossem cobertos também por outras categorias, como acontece com a subtração de objetos sagrados (bierosylia), que representa, de resto, uma categoria especial entre os casos de roubo, precisamente por ser um delito com incidência na esfera religiosa. ${ }^{10}$

Por conseguinte, mantém-se a dúvida básica em relação aos limites legais precisos em que se poderia aplicar este processo, cenário que tem levado a maioria dos estudiosos a admitir que a multiplicidade dos casos puníveis por asebeia é uma consequência natural da elasticidade e vagueza do próprio conceito. ${ }^{11}$ Esta interpretação afigura-se ainda pertinente e encontra um paralelo,

\footnotetext{
8 Conforme refletia o termo hosios usado no passo de Platão anteriormente comentado. Não é também de pôr de lado a hipótese de que o conceito de asebeia cobrisse, em termos genéricos, a falta ao respeito devido 'às leis (nomoi) e aos governantes (archontes)', embora isso também possa estar implícito nas ofensas de pleonexia e de bybris.

9 Vide sistematização de Cohen (1991), 205-206, que fornece amplo espectro de fontes.

10 Conforme Todd (1995), 307 e n.19, salienta, o facto de haver uma ação pública específica para estes delitos (graphe hierosylias) mostra a gravidade do crime, se bem que os exemplos de casos destes fornecidos pelas fontes não tenham uma natureza linear.

11 Lipsius (1905-1915), II.359-360, foi o primeiro grande impulsionador desta posição. Perspetiva diferente em Rudhardt (1960), que entende, pelo contrário, que a asebeia tinha uma incidência legal clara e aplicável apenas a determinado tipo de faltas.
} 
de resto, nas dificuldades para definir o alcance legal de um processo por bybris ('insolência'), destinado a punir atentados contra a dignidade de outra pessoa. ${ }^{12}$ No entanto, a não definição clara da natureza de um crime para o qual são estipuladas determinadas penas é uma limitação característica do sistema legal ático, bem como de outros códigos antigos (com a usual exceção do homicídio). ${ }^{13}$ Esta circunstância, aliada ao falto de, em Atenas, os tribunais serem constituídos por cidadãos comuns e não por especialistas, deixava um maior espaço de manobra à intervenção reguladora da comunidade, representada pelo coletivo de juízes, em cujo consciente entrariam em linha de conta posições semelhantes às enunciadas nos dois textos que serviram de mote a esta reflexão. Ora seria a partir deste conjunto de fatores que se avaliava a justeza legal de uma acusação de asebeia.

É também frequente partir do princípio de que os processos de asebeia seriam motivados por desvios na prática ritual e não pela expressão de opiniões religiosas pouco ortodoxas, isto é, por atos e não tanto por palavras e pelas ideias que as motivavam. ${ }^{14}$ Este cenário sofreria uma alteração com os efeitos da chamada Aufklärung grega, decorrente do ensino sofista, que se traduziu, entre outros aspetos, também numa abordagem crítica da visão religiosa tradicional. Não cabe agora entrar nessa discussão igualmente complexa. No entanto, valerá a pena salientar que algumas fontes mais tardias referem uma série de processos de asebeia instaurados contra intelectuais como Protágoras e Anaxágoras. ${ }^{15}$ Em termos legais, o passo que marcaria a reação contra esses perigos de ateísmo seria um decreto promulgado por certo Diopites, talvez cerca de 430, portanto na última fase do governo de Péricles e nos primeiros momentos da Guerra do Peloponeso, numa altura em que, segundo as fontes, além de Anaxágoras, outras

12 Cf. a definição apresentada por Demóstenes (21.45-48) e por Ésquines (1.15-17). De resto, não deixa de ser significativo que, no passo do Sobre as Virtudes e os Vícios, a asebeia e a hybris apareçam ambas entre as formas que caracterizam um comportamento desviante.

13 De resto, Aristóteles ( $R$ h. 1374a) já apontava os inconvenientes que decorriam da insuficiente definição dos crimes, discutindo, entre outros exemplos, as acusações de hierosylia e de bybris. Vide as observações de Cohen (1991) 207-209.

14 E.g. MacDowell (1978) 200.

15 Cf. Diodoro, 12.39.2; Plutarco, Nic. 23. Uma das versões da acusação referida por Diógenes Laércio é particularmente elucidativa (2.12.4-8): "Com efeito, Sócion, no livro Sobre a Sucessão dos Filósofos, afirma que Anaxágoras foi acusado de impiedade (asebeia) por Cléon, por haver dito que o sol era uma massa incandescente. A defesa foi assumida por Péricles, seu discípulo, mas ainda assim foi condenado a uma multa de cinco talentos e ao exílio.” 
pessoas próximas do estadista (Fídias e Aspásia) terão sido alvos de processos judiciais. ${ }^{16}$ A informação é facultada por Plutarco (Per. 32.2), em termos que valerá a pena recordar:

Então Diopites propôs um decreto (psephisma), segundo o qual quem não acreditasse nas divindades (ta theia) ou ministrasse ensinamentos sobre fenómenos celestes, seria sujeito a um processo de eisangelia ('denúncia pública'), dirigindo as suspeitas contra Péricles, por causa de Anaxágoras.

À parte as eventuais manobras políticas que terão acompanhado a promulgação deste decreto e dos processos atrás mencionados, afigura-se claro deduzir que o seu âmbito de aplicação visava de forma direta filósofos como Anaxágoras e representaria a primeira tentativa legal de alargar a incidência jurídica da asebeia, de maneira a nela incluir também a expressão de ideias ateístas, além das práticas rituais consideradas ímpias. ${ }^{17}$ Contudo, estas hipóteses só podem ser avançadas com alguma reserva, já que Plutarco é o único autor a mencionar o decreto de Diopites e nenhuma fonte próxima dos acontecimentos confirma a existência dos referidos processos contra filósofos.

Por conseguinte, o outro processo de impiedade que poderá contribuir para sustentar a hipótese de uma extensão da asebeia também às convicções interiores é o julgamento de Sócrates, sobre o qual há muita informação contemporânea dos eventos, pese embora a parcialidade ideológica que possa, com alguma legitimidade, ser-lhe apontada. Não cabe agora discutir os pormenores do processo movido ao filósofo; ${ }^{18}$ mais importante, para a presente discussão, é saber se as alegadas crenças de Sócrates poderiam servir de base à acusação,

16 Curiosamente, Plutarco (Per. 32.1) sustenta que Aspásia foi também acusada de asebeia. A veracidade histórica desta informação tem sido posta em causa, mas, a ter existido esse processo, é improvável que a asebeia fosse motivada pela afirmação de ideias ateístas, à imagem do que aconteceu com Anaxágoras. Talvez tivesse que ver com o facto de ela ter entrado em locais (como santuários) ou participado em rituais que lhe estavam vedados por causa das liberalidades da sua vida privada. Ainda assim, o facto de o acusador ser um comediógrafo tem levado a pôr a hipótese de esta tradição se basear somente numa cena de comédia. Vide Stadter (1989) 297-298.

17 Estudiosos como Dodds (1971), 189, serviram-se deste passo para ilustrar as marcas de intolerância política em Atenas.

18 Entre os estudos mais recentes dedicados a esta questão, vide Scholz (2000); Brickhouse \& Smith (2002). Estes últimos fornecem uma coletânea das fontes antigas ligadas ao processo, além de analisarem a controvérsia, entre os estudiosos modernos, decorrente da interpretação daquelas mesmas fontes. 
independentemente de corresponderem ou não à verdade. Valerá a pena, por isso, evocar os termos exatos em que a acusação teria sido feita, tal como nos é transmitida por dois dos testemunhos mais importantes, Platão e Xenofonte: ${ }^{19}$

Platão, Ap. 24b-c: Tentarei agora responder a Meleto, este homem virtuoso e amigo da sua cidade, como ele próprio diz, e aos meus últimos acusadores. Tal como fizemos com os outros, comecemos por recordar a sua declaração jurada. Ela foi feita mais ou menos nestes termos: "Sócrates é culpado (adikein) de corromper a juventude e de não crer nos deuses (theoi) em que crê a cidade, mas em divindades novas (daimonia kaina)." Este o teor da acusação.

Xenofonte, Mem. 1.1.1: Muitas vezes me tenho perguntado, perplexo, com que argumentos aqueles que acusavam (grapsamenoi) Sócrates convenceram os Atenienses de que a sua morte era um bem para a cidade. A acusação (graphe) que apresentaram contra ele dizia qualquer coisa como: "Sócrates é culpado (adikei) de não reconhecer os deuses (theoi) que a cidade reconhece e de, em sua vez, ter introduzido divindades novas (kaina daimonia); e é culpado (adikei) também de corromper os mais novos."

Os termos da acusação encontram-se muito próximos, nos dois textos, de forma que ambos se devem ter baseado num documento oficial. ${ }^{20}$ Por outro lado, tanto Platão como Xenofonte parecem indicar, de forma clara, que o motivo próximo da acusação estava ligado, efetivamente, a uma visão pouco abonatória da religião tradicional (ao não crer nos deuses da cidade e ao defender a introdução de outros novos), bem como à divulgação dessas ideias, em particular entre os jovens que auferiam do seu magistério. Por conseguinte, o que está em causa, além do carácter provocador do comportamento de Sócrates, é também e talvez sobretudo o cultivo e expressão de uma ideologia religiosa aparentemente contrária à visão ortodoxa. ${ }^{21}$

\footnotetext{
19 Para a tradução, usa-se respetivamente a versão portuguesa de Pulquério (1991) e de Pinheiro (2009).

20 Cf. Diógenes Laércio, 2.40.

21 Desenvolvimento desta argumentação em Cohen (1991) 212-217.
} 
Xenofonte (secundado aliás por Diógenes Laércio, 2.40) usa o termo graphe para designar o tipo de acusação, o que deixa prever que o julgamento de Sócrates resultara de uma graphe asebeias, portanto de um processo público normal. Contudo, no decreto de Diopites falava-se de eisangelia, que é um tipo de procedimento mais excecional, iniciado pelo fornecimento direto de informação à Ekklesia ou à Boule. Isto coloca a questão de saber se o processo usual durante o séc. v seria a eisangelia e se, talvez como resultado do esforço de revisão legislativa, terá passado ou não a graphe. As dúvidas relativas à autenticidade do decreto de Diopites não facilitam a análise do problema, mas não se afigura improvável que o processo mais usual fosse a graphe, tanto no séc. v como no iv, mas que a eisangelia também pudesse ser aplicada em casos que se afigurassem mais sérios. ${ }^{22}$ É isso que terá acontecido a propósito do envolvimento (real ou fictício) de Alcibíades no escândalo que abalou Atenas em 415, nas vésperas da expedição à Sicília, que se traduziu na mutilação das estátuas de Hermes e na paródia aos Mistérios de Elêusis. Este duplo sacrilégio iria motivar, de resto, uma verdadeira histeria coletiva, que levaria a soberania popular a cometer sucessivos erros de governação. ${ }^{23}$ Por comparação, o processo movido contra Sócrates e outros filósofos terá produzido um impacto relativamente menor na opinião pública, embora a morte do filósofo transitasse para a posteridade, sobretudo por influência de Platão, como exemplo de um dos 'pecados mortais' da democracia ateniense, tornando Sócrates numa espécie de mártir do pensamento libertador. É nessa perspetiva que a memória do crime de asebeia em geral e a natureza das acusações a Sócrates em particular interessam para a análise das acusações que visaram Paulo.

\subsection{Paulo em Filipos, Corinto e Atenas}

No decurso das suas missões apostólicas (Atos dos Apóstolos, 15.35-21.16), Paulo faculta uma notável imagem de viajante, descrevendo uma impressionante rota através do Mediterrâneo oriental que o leva não apenas a zonas profundamente

\footnotetext{
22 Perspectiva sustentada por MacDowell (1978) 183-184; 199-200.

23 De resto, Alcibíades só parece ter estado envolvido no crime de paródia aos Mistérios de Elêusis. Para uma análise deste processo, vide Leão (2004) 205-220.
} 
helenizadas como ao coração da própria Grécia, ao visitar cidades como Filipos, na Macedónia, Atenas e Corinto. Em todas estas cidades viverá experiências marcantes do ponto de vista doutrinário, mas que são igualmente elucidativas da sua capacidade para argumentar e adaptar-se à realidade sociológica e às expetativas culturais das audiências com que se deparava. Conforme se dizia na secção introdutória (supra 8.1), neste contexto geográfico o cosmopolitismo de Paulo encontra igualmente uma expressão de eleição, porquanto era um judeu, que gozava de cidadania romana, ao mesmo tempo que desenvolvia a missão apostólica em território helénico. As tensões derivadas do esforço de harmonização destas três forças centrífugas afloram em vários momentos dos Atos dos Apóstolos, potenciadas pela tarefa de anunciar uma ideologia religiosa onde a tradicional prática ritualista da salvação através da lei (15.1.5) se via ultrapassada pela salvação garantida através da fé em Cristo (15.7-11). A mensagem evangélica possuía, por conseguinte, alguns dos elementos que poderiam resgatar da poalha dos tempos a reminiscência das antigas acusações de asebeia. O termo não chega a ser usado expressamente, mas não será abusivo argumentar que o velho conceito continuava operativo na memória coletiva helénica, mesmo que dela não houvesse uma consciência clara.

Com efeito, Filipos, sendo embora uma colónia romana organizada à imagem da metrópole, não deixava de se encontrar em espaço grego e de acusar essa influência helénica. ${ }^{24}$ De resto, isso mesmo vem confirmado no momento em que Paulo e Silas se cruzam com uma escrava que possuía a poder da adivinhação (16.16):

Um dia, quando íamos à oração, encontrámos uma serva que tinha um espírito pitónico (pneuma pythona) e dava muito lucro aos seus senhores, exercendo a adivinhação (manteuomene). ${ }^{25}$

Teria sido fácil ao autor dos Atos optar por uma expressão mais neutral para designar as capacidades divinatórias da escrava (e.g. pneuma mantikon), mas a opção pelo termo pythona estabelece uma relação direta com o imaginário ligado à atuação da Pítia, profetisa de Apolo no santuário de Delfos, o representante

\footnotetext{
24 Sobre o estatuto de Filipos enquanto colónia romana, vide Omerzu (2002) 116-123.

25 Para a tradução de passos da Bíblia, adota-se a versão da Nova Bíblia dos Capuchinhos (Lisboa, 1998).
} 
máximo do legalismo na religião grega. Discretamente, é assim estabelecida uma oposição entre o influxo desta falsa forma de religiosidade e a atuação do Espírito Santo, que vela pelo trabalho dos apóstolos e marcará a sua superioridade ao permitir-lhes exorcizar a escrava. Este confronto de duas manifestações religiosas será depois transposto para o plano humano, quando os donos da escrava decidem acusar formalmente Paulo e Silas (16.19-21):

Mas os senhores da escrava, vendo desaparecer a esperança do lucro (ergasia), apoderaram-se de Paulo e de Silas e arrastaram-nos até à praça pública, à presença dos magistrados (strategoi). Apresentando-os aos estrategos, disseram: «Estes homens espalham a desordem na nossa cidade (polis); são judeus, e apregoam usos (ethe) que não nos é permitido a nós, romanos, nem admitir nem praticar.

A propósito deste episódio, são discutidos quer o motivo que terá levado os donos da escrava a acusarem formalmente os apóstolos, quer a natureza objetiva da acusação. ${ }^{26}$ Ainda assim, a motivação apontada por Lucas afigura-se bastante convincente. Com efeito, ao longo dos Atos dos Apóstolos fica bem patente que a prática da adivinhação era um negócio que envolvia bastantes recursos (e.g. 19.19), de maneira que o móbil dos donos terá sido a perda de uma importante fonte de rendimento, decorrente da danificação do principal atributo que distinguia a escrava. ${ }^{27}$ Quanto à natureza da acusação formal, faz recordar, de maneira bastante próxima, o crime de asebeia evocado na secção anterior: perturbar a ordem da cidade (significativamente, usa-se o termo típico para designar a cidade-estado ou polis) e visar a introdução de costumes (ethe) cuja prática era vedada aos locais.

Um outro exemplo ocorre em Corinto, quando Paulo foi novamente levado a tribunal (18.12-13):

26 Para uma análise de algumas das principais interpretações, vide de Vos (1999), que se inclina para a ideia de que os donos da escrava teriam acusado Paulo da prática de magia com o intuito de provocar danos a outrem. Análise mais sistemática da natureza da acusação em Omerzu (2002) 124-141.

27 É bastante significativo notar que Simão (8.9-11), antes de se ter convertido, se dedicava com sucesso à arte da magia. E ao perceber que o Espírito Santo era concedido através da simples imposição das mãos, tentou comprar esse dom, com a oferta de dinheiro, para grande escândalo de Pedro e João (8.18-24). 
Sendo Galião procônsul da Acaia, levantaram-se os judeus, de comum acordo, contra Paulo e levaram-no a tribunal. «Este homem - disseram eles - induz as pessoas a prestar culto (sebesthai) a Deus (theos) de uma forma contrária à lei (para ton nomon).»

Embora a acusação seja movida por judeus e não por Gregos, é curioso notar que os termos evocam, novamente, o imaginário ligado à asebeia. De facto, o conceito aparece referido de forma indireta quando é sustentado que Paulo incitava as pessoas a prestar culto (sebesthai) de forma contrária à lei (para ton nomon). A acusação pretende, obviamente, expor uma prática incorreta de rituais determinados por lei. Ora é interessante notar que, em relação aos escândalos que abalaram Atenas em 415 a.C. e à atuação de Alcibíades, certamente a figura mais 'mediática' de quantos foram envolvidos nesses crimes de asebeia, Tucídides (6.28.2) afirme que os inimigos políticos do estadista classificavam o seu comportamento irreverente como um desprezo pela legalidade (paranomia). ${ }^{28}$ Daqui será legítimo depreender que, volvidos embora muitos séculos, o consciente coletivo continuava a funcionar com um padrão mental idêntico, na altura de definir as formas de impiedade religiosa.

Curiosamente, o trabalho de Paulo havia de encontrar maior compreensão em Atenas, a mesma cidade onde, cerca de cinco séculos antes, a população havia movido vários processos de asebeia contra figuras ilustres de filósofos e notáveis comunicadores. Isso verifica-se na altura em que ele profere o famoso discurso diante do Areópago, onde simbolicamente o apóstolo de Cristo quase parece absolver, de forma implícita, os Atenienses pela morte de Sócrates, salientando agora a 'piedade' ou eusebeia que tão singularmente os distingue (17.22-23):

De pé, no meio do Areópago, Paulo disse, então: «Atenienses, vejo que sois, em tudo, os mais religiosos dos homens. Percorrendo a vossa cidade e examinando os vossos monumentos sagrados (sebasmata), até encontrei um altar com esta inscrição: 'Ao deus desconhecido.' Pois bem! O que venerais (eusebeite) sem conhecer é o que eu vos anuncio.»

28 Vide Leão (2004) 213-214. 
Como resposta à acusação implícita de que a sua atividade missionária era uma forma de asebeia, Paulo vem esclarecer, junto de um auditório que estaria bem familiarizado com esse conceito de impiedade religiosa, que o objeto da sua pregação é, bem pelo contrário, a manifestação da verdadeira eusebeia - a mesma aliás que os Atenienses já veneravam, de forma inconsciente, ao dedicarem um altar 'ao deus desconhecido'.

No seu estatuto multifacetado de grego, romano, judeu e cristão, Paulo de Tarso constitui em si mesmo um exemplo particularmente elucidativo da experiência do cosmopolitismo na antiguidade, enquanto repositório de tradições múltiplas e variadas. Com a análise do seu testemunho, chega também ao seu termo a abordagem da longa evolução que, do particularismo da pólis e do envolvimento direto de cada polites nos assuntos da comunidade, conduziria à emergência de um universo globalizado e profundamente marcado pela fusão étnica, política, legal e religiosa, mas onde continuava, apesar de tudo, a haver lugar para a afirmação do indivíduo e das suas convicções interiores. 


\section{BIBLIOGRAFIA CITADA}

Alcalde MarTín, Carlos

— 1999: "Rasgos socráticos de la personalidad de Foción en la Vida de Plutarco", in A. Pérez Jiménez, J. García López \& Rosa María Aguilar (eds.), Plutarco, Platón y Aristóteles (Madrid), 159-171.

- 2001 Plutarco. Vida de Foción. Introducción, traducción y notas (Madrid). AlexANDER, Loveday

- 2001: "Acts", in J. Barton \& J. Muddiman: The Oxford Bible commentary (Oxford), 1028-1061.

ANDREwes, A.

- 1992: "The Spartan resurgence", in D. M. Lewis, J. Boardman, J. K. Davies \& M. Ostwald (eds.), The Cambridge ancient history. Volume V. The fifth century B.C. (Cambridge, reimpr. 2006), 464-498.

BADIAN, E.:

- 1958: "Alexander the Great and the unity of mankind", Historia 7, 425-444. [= G. T. Griffith (ed.), Alexander the Great - the main problems (Cambridge, 1966), 287-306].

Bearzot, Cinzia

- 1993: "Introduzione", in Plutarco. Focione e Catone Uticense (Milano), 91-151. [reimpr. 2001]

- 2007: "Autoctonia, rifiuto della mescolanza, civilizzazione: da Isocrate a Megastene", in T. Gnoli e F. Muccioli (eds.), Incontri tra culture nell'oriente ellenistico e romano (Milano), 7-28.

BisCARDI, Arnaldo

- 1982: Diritto greco antico (Varese).

BLoK, Josine $\mathrm{H}$.

- 2009: "Gentrifying genealogy: on the genesis of the Athenian autochthony myth", in U. Dill \& C. Walde (hrsg.), Antike Mythen. Medien, Transformationen und Konstruktionen (Berlin), 251-275.

Brickhouse, Thomas C. \& Smith, Nicholas D. (eds.)

- 2002: The trial and execution of Socrates. Sources and controversies (New York).

Cartledge, Paul

- 2003: The Spartans. An epic history (London).

- 2007: Thermopylae. The battle that changed the world (New York).

Castiajo, Isabel

- 2012: O teatro grego em contexto de representação (Coimbra). [no prelo] 
Clayton, P. A.

- 1988, "The Pharos at Alexandria", in P. A. Clayton \& M. J. Price (eds.), The Seven Wonders of the ancient world (London), 138-157.

Clayton, P. A. \& Price, M. J. (eds.)

- 1988: The Seven Wonders of the ancient world (London).

Csapo, Eric \& Slater, William J.

- 1998: The context of ancient drama (Ann Arbor).

Cohen, David

— 1991: Law, sexuality, and society. The enforcement of morals in classical Athens (Cambridge).

Cohen, Edward E.

- 2000: The Athenian nation (Princeton).

Conacher, D. J.

- 1967: Euripidean drama. Myth, theme and structure (Toronto).

DoDDs, E. R.

- 1971: The Greeks and the irrational (Berkeley).

ERSKINE, A.

- (1995): "Culture and power in Ptolemaic Egypt: the Museum and Library of Alexandria", G\&R 42, 38-48.

Feldman, Louis H. \& Reinhold, Meyer

- 1996: Jewish life and thought among Greeks and Romans. Primary readings (Edinburgh).

Fernandes, Raul M. Rosado \& Granwehr, M. Gabriela

- 2010: Tucídides. História da Guerra do Peloponeso. Tradução do grego, prefácio e notas introdutórias (Lisboa).

Ferreira, José Ribeiro

- 1992: Hélade e Helenos. I - Génese e evolução de um conceito (Coimbra).

— 2004: "Próxeno e proxenia", in D. F. Leão, L. Rossetti \& M. do Céu Fialho (eds.), Nomos. Direito e sociedade na antiguidade clássica / Derecho y sociedad en la antigüedad clásica (Coimbra e Madrid), 227-239.

- 2010: "A presença da Grécia e de Roma na Revolução francesa: três aspectos", in D. F. Leão, J. Ribeiro Ferreira \& Maria do Céu Fialho, Cidadania e paideia na Grécia antiga (Coimbra), 173-208.

Ferreira, José Ribeiro \& Leão, Delfim F.

- 2010: Dez grandes estadistas atenienses (Lisboa).

FERreira, José Ribeiro \& SiLVA, Maria de Fátima

- 1994: Heródoto. Histórias - Livro $1^{\circ}$ (Lisboa).

Fialho, Maria do Céu

- 2008: "Sócrates e a paideia falhada de Alcibíades", in C. Soares, J. Ribeiro Ferreira \& M. C. Fialho, Ética e Paideia em Plutarco (Coimbra), 31-46.

- 2010a: "Rituais de cidadania na Grécia Antiga" in D. Leão, J. R. Ferreira, M. C. Fialho, Cidadania e paideia na Grécia antiga (Coimbra), 111-144.

- 2010b: "The interplay of textual references in Plutarch's Life of Phocion", in Françoise Frazier \& Delfim F. Leão (eds.): Tychè et pronoia. La marche du monde selon Plutarque (Coimbra et Paris), 195-205. 
FLOWER, Michael

- 2000: "Alexander the Great and panhellenism", in A. B. Bosworth \& E. J. Baynham, Alexander the Great in fact and fiction (Oxford), 96-135.

FORSDYKe, Sara

- 2005: Exile, ostracism, and democracy. The politics of expulsion in ancient Greece (Princeton).

VON FRITZ, Kurt \& KAPP, Ernst

- 1974: Aristotle's Constitution of Athens and related texts (New York).

Gambetti, Sandra

2009: The Alexandrian riots of 38 C.E. and the persecution of the Jews: a historical reconstruction (Leiden).

GeIGer, Joseph

- 1999: "Plato, Plutarch and the death of Socrates and of Cato", in A. Pérez Jiménez, J. García López \& Rosa María Aguilar (eds.), Plutarco, Platón y Aristóteles (Madrid), 357-364.

Gomme, A. W.

- 1945-1956: A Historical Commentary on Thucydides: Books I-V24. vols. I-III (Oxford).

Gomme, A. W. \& Andrewes, A. \& Dover, K. J.

- 1970-1981: A Historical Commentary on Thucydides: Books V25-VIII. Vols. IV-V (Oxford),

Guthrie, W. K. C.

- 1981: A history of Greek philosophy. Vol. VI (Cambridge).

Hammond, N. G. L.

- 1986: A bistory of Greece to 322 B.C. (Oxford). [3 $3^{\mathrm{a}}$ ed. revista]

- 1989: Alexander the Great - king, commander and statesman (Bristol).

- 1997: The genius of Alexander the Great (London).

Harris, Edward M., Leão, Delfim F. \& Rhodes, Peter J. (eds.)

- 2010: Law and drama in ancient Greece (London).

HARrison, A. R. W.

— 1968-1971: The law of Athens. II vols. (Oxford).

Heckel, Waldemar \& Yardiey, J. C.

- 2004: Alexander the Great. Historical sources in translation (Malden).

Hegermann, Harald

- 1989: "The Diaspora in the Hellenistic age", in W. D. Davies \& L. Finkelstein, The Cambridge history of Judaism (eds.) (Cambridge), 115-167. [reimpr. 2007]

Hengel, Martin

- 1989: "The interpenetration of Judaism and Hellenism in the pre-Maccabean period", in W. D. Davies \& L. Finkelstein, The Cambridge history of Judaism (eds.) (Cambridge), 167-228. [reimpr. 2007]

HOOKER, J. T.

- 1980: The ancient Spartans (London).

LAMBERT, Stephen D.

- 2006: "Athenian state laws and decrees, 352/1-322/1: III decrees honouring foreigners. A. Citizenship, proxeny and euergesy”, ZPE 158, 115-158. 
LEÃO, Delfim F.

- 2001: Sólon. Ética e política (Lisboa).

- 2004: "Matéria religiosa: processos de impiedade (asebeia)", in D. F. Leão, L. Rossetti \& M. do Céu Fialho (Coords.), Nomos. Direito e sociedade na antiguidade clássica / Derecho y sociedad en la antigüedad clásica (Coimbra e Madrid), 201-226. - 2005a: "Alexandre Magno: da estratégia pan-helénica ao cosmopolitismo", in A. Casanova (coord.), Atti del convegno internazionale di studi "Plutarco e l'età ellenistica" (Firenze), 23-37.

- 2005b: "O horizonte legal da Oresteia. O crime de homicídio e a fundação do tribunal do Areópago", Humanitas 57, 3-38.

- 2005c: "Sólon e a legislação em matéria de direito familiar", Dike, n. s. 8, 5-31.

- 2006: "Os desencantos de Medeia: uma xene privada de kyrios, de oikos e de polis", in E. Suárez de la Torre \& Maria do Céu Fialho (eds.), Bajo el signo de Medea / Sob o signo de Medeia (Coimbra e Valladolid), 67-82.

- 2009: "Do polites ao kosmopolites", Anuario de Estudios Filológicos 32, 157-174.

- 2010a: "A tradição dos Sete Sábios: o sapiens enquanto paradigma de uma identidade", in D. F. Leão, J. Ribeiro Ferreira \& Maria do Céu Fialho, Cidadania e paideia na Grécia antiga (Coimbra), 47-110.

- 2010b: "Cidadania, autoctonia e posse de terra na Atenas democrática", Cadmo 20, 445-464.

- 2010c: "Tyche, kairos et chronos dans le Phocion de Plutarque", in Françoise Frazier \& Delfim F. Leão (eds.): Tychè et pronoia. La marche du monde selon Plutarque (Coimbra et Paris), 183-194.

- 2011a: "Autoctonia, filiação legítima e cidadania no Íon de Eurípides", Humanitas 63, 105-122.

- 2011b: "Paidotrophia et gerotrophia dans les lois de Solon", RHD 89.4, 457-472.

Leão, Delfim F. \& Mantas, Vasco

- 2009: "O Farol de Alexandria", in J. Ribeiro Ferreira \& Luísa de Nazaré Ferreira, As Sete Maravilhas do mundo antigo: fontes, fantasias e reconstituições (Lisboa), 109-125.

LÉVY, Edmond

— 2007: Sparta. Storia politica e sociale fino alla conquista romana (Lecce). [versão italiana da edição francesa de 2003]

LidDELl, H. G. \& ScotT, R.

- 1996: A Greek-English lexicon (Leipzig). [1843. $9^{\mathrm{a}}$ edição, com um novo suplemento revisto]

Lipsius, Justus Hermann

- 1905-1915: Das attische Recht und Rechtsverfahren. III vols. (Leipzig).

Loraux, Nicole

- 1984: Les enfants d'Athéna. Idées athéniennes sur la citoyenneté et la division des sexes (Paris).

LOURENÇO, Frederico

- 1994: Eurípides. Íon. Tradução do grego, introdução e notas (Lisboa).

- 2003: Homero. Odisseia (Lisboa).

- 2005: Homero. Ilíada (Lisboa).

MacDowell, Douglas M.

- 1978: The law in classical Athens (London).

- 1986: Spartan law (Edinburgh). 
Manfredini, Mario \& Piccirilli, Luigi

- 1995: Plutarco. Le Vite di Licurgo e di Numa (Verona). [3ª ed. revista]

Mason, Steve

- 2007: Flavius Josephus. Against Apion. Translation and commentary (Leiden).

Mathieu, Georges

- 1966: Les idées politiques d'Isocrate (Paris).

MeIER, Christian

- 1988: Die politische Kunst der griechischen Tragödie (München).

MeYer, Elizabeth A.

- 1993: "Epitaphs and citizenship in classical Athens", JHS 113, 99-121.

Miller, Michael James

- 1982: The Athenian autochthonous heroes from the classical to the Hellenistic period (Harvard). Dissert. polic.

Modrzejewski, Joseph Mélèze

- 1995: The Jews of Egypt. From Rameses II to emperor Hadrian (Illinois). (cita-se pela versão em eBook de 2001)

Monteiro, João Gouveia

- 2012: "Gaugamela (331 a.C.): Alexandre Magno - conquistar a Pérsia e depois o mundo", in Grandes conflitos da história da Europa. De Alexandre Magno a Guilherme o Conquistador (Coimbra), 17-72.

Muccioli, Federicomaria

- 2005: "Il re dell'Asia': ideologia e propaganda da Alessandro Magno a Mitridate

VI", Simblos. Scritti di Storia Antica, 105-158.

Oliveira, Francisco de

- 1991: "Condicionantes da representação teatral", in O teatro de Aristófanes,

F. de Oliveira \& M. F. Silva (Coimbra), 5-49.

OMERzu, Heike

- 2002: Der Prozeß des Paulus. Eine exegetische und rechtshistorische Untersuchung der Apostelgeschichte (Berlin \& New York).

PEČIRKA, J.

- 1966: The formula for the grant of enktesis in Attic inscriptions (Prague).

Pérez Jiménez, Aurelio

- 1985: Plutarco. Vidas Paralelas I. Teseo - Rómulo / Licurgo - Numa (Madrid).

PinheIro, Ana Elias

- 2009: Xenofonte. Memoráveis (Coimbra).

Pulquério, Manuel de Oliveira

- 1991: Platão. Apologia de Sócrates. Críton (Coimbra) [2 ed.]

Rhodes, P.J. \& Osborne, Robin

- 2003: Greek historical inscriptions. 404-323 BC (Oxford).

Rocha Pereira, Maria Helena da

- 2006: Estudos de história da cultura clássica. I volume. Cultura grega (Lisboa).

$\left[10^{\mathrm{a}}\right.$ ed. revista]

RODRIGUES, Nuno Simões

- 2005: "Um olhar a oriente: imagens do mundo semítico na literatura grega, dos Poemas Homéricos a Xenofonte", in M. C. Fialho, M. F. Silva \& M. H. da Rocha 
Pereira (coord.), Génese e consolidação da ideia de Europa. Vol. I: de Homero ao fim da época clássica (Coimbra), 335-365.

- 2007: Iudaei in Vrbe. Os Judeus em Roma de Pompeio aos Flávios (Lisboa).

Rosivach, Vincent J.

- 1987: "Autochthony and the Athenians", CQ 37, 294-306.

Rubinstein, Lene

- 1998: "The Athenian political perception of the idiotes", in P. Cartledge, P. Millett

\& S. von Reden, Kosmos: essays in order, conflict, and community in classical Athens (Cambridge), 125-143.

RUDHARDT, Jean

— 1960: "La définition du délit d'impiété d’après la législation attique", MH 17, 87-105.

SCAFURo, Adele

- 1990: "Discourses of sexual violation in mythic accounts and dramatic versions of 'the girl's tragedy'", Differences. A journal of feminist cultural studies 2.1, 126-159.

ScHolz, Peter

— 2000: "Der Prozeß gegen Sokrates. Ein 'Sündenfall' der athenischen Demokratie?", in L. Burckhardt \& J. von Ungern-Sternberg (hrsg.) Große Prozesse im antiken Athen (München), 157-173.

SILVA, Maria de Fátima

— 2011: "Delfos, um lugar de peregrinação. Eurípides, Íon”, Humanitas 63, 89-103.

STADTer, Philip A.

- 1989: A commentary on Plutarch's Pericles (Chapel Hill).

TARN, W. W.

- 1933: "Alexander the Great and the unity of mankind", $P B A$ 19, 123-166 [= G. T. Griffith (ed.), Alexander the Great - the main problems (Cambridge, 1966), 243-286].

TodD, S. C.

- 1995: The shape of Athenian law (Oxford).

Too, Yun Lee

— 1995: The rhetoric of identity in Isocrates (Cambridge).

Trapp, Michael B.

- 1999: "Socrates, the Phaedo, and the Lives of Phocion and Cato the Younger", in A. Pérez Jiménez, J. García López \& Rosa María Aguilar (eds.), Plutarco, Platón y Aristóteles (Madrid), 487-499.

VALdés Guía, Miriam

- 2008: El nacimiento de la autoctonía ateniense: cultos, mitos cívicos y sociedad de la Atenas del s. VI a.C. (Madrid).

DE Vos, Craig S.

- 1999: "Finding a charge that fits: the accusation against Paul and Silas at Philippi (Acts 16.19-21)", Journal for the Study of the New Testament 74, 51-63.

Whitehead, David

- 1977: The ideology of the Athenian metic (Cambridge, PCPS suppl. 4).

Wiles, David

- 2000: Greek theatre performance. An introduction (Cambridge).

Wilamowitz-MoEllendorfF, Ulrich von

- 1926: Euripides Ion (Weidmann, reimpr. 1969). 


\section{ÍNDICE DE NOMES}

Abdera: 119;

Acaia: 141;

Acrópole: 18; 39; 50;

Ada: 107;

Agamémnon: 33-34;

Ágis IV (rei de Esparta): 42-43;

Agripa: 130 n. 2;

Alcibíades: 19-20; 61-64; 88-90; 95; 138; 141 ;

Alexandre (filho de Alexandre Magno): 25;

Alexandre Magno: 11-12; 23-24; 25; 65; 90; 91; 97-110; 111-112; 119-121; 122; 125;

Alexandria: 12; 26 n. 16; 111-127;

Aliança Grega: 36-37; 39;

Amiclas: 34;

Ámon: 109; 121 e n. 23;

Anaxágoras: 135-136;

Antestérias: 70 n. 2;

Antifonte: 19 n. 8;

Antíoco III: 122 n. 26;

Antípatro: 91-93; 95;

Antirrodes: 116-117;

Apolo: 17 e n. 4; 36; 44; 45; 47; 75-83; 131-132; 138-139;

Aquiles: 102 e n. 12; 103; 131 n. 4;

Arcádia: 105;

Areópago: 68; 141-142;

Arginusas: 21; 63;
Arísteas: 124-125; 126;

Aristides: 40;

Aristobulo: 103 n. 16;

Aristogíton: 105;

Aristófanes: passim.

Aristóteles: passim.

Arquidamo de Esparta: 101;

Arriano: 97; 109 n. 34; 110;

Artaxerxes III Oco: 108 n. 31;

Ártemis: 105;

Artemísio: 37-39;

Ásia: 23; 25; 102-103; 104-105; 111; 113;

Ásia Menor: 50; 106; 118;

Asiáticos: 106; 107-108; 110;

Aspásia: 136 e n. 16;

Atena: 41; 75-83; 103;

Atena Silânia: 46;

Atenas: passim.

Atenienses: passim.

Ática: passim.

Atridas: 35;

Augeias: 34;

Augusto: 24;

Bábica: 46;

Babilónia: 105; 112; 114; 121;

Bel: 120;

Berenice: 117; 
Biblioteca de Alexandria: 12; 114; 123;

Boedrómion: 92;

Briseias: 34;

150 Cábrias: 90;

Calcodôntidas: 76;

Calístenes: 108 n. 30; 109;

Castor: 117;

Catão o Jovem: 90 n. 11; 94 n. 23;

Cécrops: 51 n. 7; 76 n. 18;

Cerices: 131;

César: 98;

Chipre: 101;

Cínicos: 30-31;

Clearco: 118;

Cleofonte: 21; 63;

Cleômbroto: 39;

Cleómenes III (rei de Esparta): 42-43;

Cléon: 135 n. 13;

Clístenes: 18; 65;

Clito: 93; 109;

Cnácion: 46;

Cnidos: 116-117;

Cónon: 64;

Congresso Helénico: 37; 39;

Congresso do Istmo: 37;

Conselho Anfictiónico: 23;

Corinto: 22; 64 n. 38; 105; (Guerra de): 22; (Liga de): 23; 100; 105; 138-142;

Creta: 45; 118;

Creúsa: 75-83;

Crises: 131 n. 4;

Cristãos: 131;

Cristo: 12; 129; 131; 139; 141;

Crítias: 20 n. 10;

Crocodilópolis: 126 n. 39;

Crotona: 105;

Crotoniatas: 104;

Cúrcio Rufo: 97; 109 n. 34; 109 n. 35;

Daniel: 121;
Dario III: 104-105; 107; 108 n. 31;

David: 118;

Decelia: 62;

Delfos: 17; 36; 39 n. 14; 44; 46; 138-139;

Delos: 18; 72; 131-132; (vd. Simaquia de Delos)

Delta do Nilo: 113 n. 4; 114; 115;

Demades: 89 n. 4;

Demarato: 105;

Demétrio de Fáleron: 73-74; 123 e n. 32; 124-125;

Demétrio Poliorcetes: 29;

Demóstenes: passim.

Dexífanes: 117;

Dez: 22;

Diádocos: 25-26; 90; 113;

Dinócrates: 113 n. 4;

Diodoro Sículo: passim.

Diógenes (filósofo cínico): 31 n. 21;

Diógenes Laércio: passim.

Dionísias Rurais: 70 n. 2;

Dionísias Urbanas: 70 n. 2; 73 n. 16; (vd. Grandes Dionísias)

Dionísio de Siracusa: 101;

Diónisos: 72;

Diopites: 135-136; 138;

Dioscuros: 117 ;

Dórios: 52 n. 11;

Dosíteo: 126 n. 39;

Drácon: 65;

Ecbátana: 106;

Édipo: 73 ; 79 n. 26;

Efialtes: 18; 68;

Egeu: 50;

Eginetas: 39 n. 15;

Egipto: 25; 112; 113-118; 119 e n. 17; 122; 126 ;

Egípcios: 118;

Egospótamos: 21; 63-64;

Electra: 73; 
Elêusis (Mistérios de): 29 n. 20; 62; 89; 91-93; 94 n. 21; 95; 131-132; 138;

Emílio Paulo: 98;

Éolo: 76; 79;

Erecteu: 51 n. 7; 53; 75-83;

Erictónio: 51 n. 7; 53; 75-83;

Esfinge: 79 n. 26;

Esparta: passim.

Espartanos: passim.

Espírito Santo: 140 e n. 27;

Ésquilo: 34; 68; 73 n. 14; 74;

Estagirita: 108 n. 30;

Estatira: 108 n. 31;

Estrabão: 115-117;

Étilo: 34;

Eubeia: 76;

Eumólpidas: 131;

Eunosto: 116;

Euribíades: 37; 39;

Eurípides: 11; 54 n. 17; 65; 68; 74; 75-83;

Europa: 23; 111;

Europeus: 107-108; 110;

Ezequias: 122-125;

Fáleron: 73; 123;

Fáris: 34;

Farol de Alexandria: 12; 111-118; (vd. Torre de Faros)

Faros: 114-118;

Faulo: 104;

Febo: 78;

Fénix: 102 n. 12;

Feras: 101;

Festo: 130 n. 2;

Fídias: 50; 136;

Filarco: 43 n. 21;

Filipe: 23; 25; 65; 90; 100-102; 104; 105;

Filipos: 129; 130-131; 138-142;

Flávio Josefo: 118 n. 14; 119-121; 122 n. 26 e 28 ; 122 n. 28 ; 124-126;
Fócion: 11; 28; 29 n. 19; 88-96;

Galião: 141;

Gaugamelos: 104-105;

Gaza: 122;

Gélon: 52;

Gerusia: 46;

Golfo Sarónico: 37;

Grande Porto: 116-117;

Grandes Dionísias: 69; 70 n. 2; 73 e n. 16; (vd. Dionísias Urbanas)

Granico: 103;

Grécia: passim.

Gregos: passim

Guerra do Peloponeso: 11; 17-22; 42; 50

n. $3 ; 59-61 ; 65 ; 69 ; 86 ; 90-92 ; 100 ; 102$

n. $11 ; 135-136$;

Guerra Social: 22;

Guerras Medo-persas: 17-18; 36; 50; 105;

Hágnon: 20;

Halicarnasso: 107; 112; 115;

Harmódio: 105;

Hecateu de Abdera: 119;

Hélade: passim.

Helena: 33-36; 115 n. 8;

Helenos: passim.

Helesponto: 103;

Helo: 34;

Heptastádion:

Héracles: 102 e n. 12;

Heraclidas: 43; 52 n. 11;

Hermes: 75-83; (mutilação dos): 62; 138;

Heródoto: passim.

Hilotas: 37; 41;

Homero: 33-34; 41; 44; 53; 115; 131 n. 4;

Iaco: 92;

Indianos: 118;

Íon: 118; (tragédia homónima de Eurípides): 11; 54 n. 17; 65; 68; 75-83; Isócrates: 42; 53 n. 14; 100-102;124 n. 34; Ítaca: 34; 
Itália: 104;

Itálicos: 104;

Jafet: 118;

152 Jápeto: 118;

Jasão de Feras: 101;

Javan: 118;

Jerusalém: 13; 119-121; 122 n. 26; 129; 130 ;

Jesus: 12; 129;

João: 140 n. 27;

Judeia: 122;

Judeus: 118-127;

Justino: 97; 109 n. 35;

Laas: 34;

Lacedemónia: 34; 36; 42;

Lacedemónios: 36; 37; 41; 44-45; 64; 64 n. $38 ; 104$;

Laio: 79 n. 26;

Láurion: 62;

Leneias: 70 n. 2; 73;

Leobotas: 45 ;

Leónidas: 37-40; 41;

Leuctras (batalha de): 22; 102 n. 11; 105;

Lex Porcia: 129;

Líbia: 121;

Liceu: 118 ;

Licurgo (legislador espartano): 10; 33-48;

Licurgo (orador): 42;

Lisandro: 21;

Lisícrates: 72 n. 11;

Lisímaco: 102 n. 12;

Longas Muralhas: 64;

Lóquias: 116-117;

Lóxias: 76;

Lucas: 140 ;

Luciano de Samósata: 117;

Macedónia: 11; 22; 25; 37; 65; 90; 91 n. 15; 100; 102; 102 n. 11; 103; 105; 110; 113; 114; 139;
Macedónios: 100 n. 7; 105; 106; 108; 109 n. $33 ; 110 ; 121$;

Maratona: 17; 36; 40;

Mardónio: 39-40;

Mausoléu de Halicarnasso: 115;

Medeia: 68; 69; 73;

Média: 121;

Mediterrâneo: 23; 111; 138;

Meleto: 137;

Menandro: 31 n. 22;

Menelau: 33-36; 115;

Menéxeno: 54; 58-59;

Mênfis: 113-114;

Menilo: 92;

Messa: 34;

Messénia: 36;

Micenas: 33;

Moisés: 119 e n. 17;

Muníquia: 91;

Musas: 114;

Museu de Alexandria: 12; 114;

Naxos: 90-92; 95;

Nícias: 62;

Nícocles de Chipre: 101;

Nilo: 113 n. 4;

Numa: 43;

Olimpíadas: 43;

Onesícrito: 99 n. 5;

Onze: 22;

Ópis: 110;

Palestina: 118;

Páris: 33; 35;

Parisátis: 108 n. 31;

Parménion: 103;

Pártenon: 50;

Pátroclo: 131 n. 4;

Paulo: 12-13; 110; 127; 129-142;

Pausânias (escritor): passim. 
Pausânias (comandante espartano, sobrinho de Leónidas): 40-41; 42;

Pausânias (rei de Esparta, ativo na última fase da Guerra do Peloponeso): 22;

Pedro: 140 n. 27;

Peloponésios: 20; 64 n. 38;

Peloponeso: 37; 52 n. 11; (vd. Guerra do; Simaquia do)

Penélope: 34-35;

Pentateuco: 123;

Pérgamo: 25; 113;

Péricles: 18-19; 22; 49; 51; 53; 59-62; 65; 68; 79; 81; 86; 88; 135-136;

Peripatéticos: 108 n. 30;

Persas: passim.

Persépolis: 105-106;

Pérsia: passim.

Píndaro: 38;

Pireu: 22; 60; 64;

Pisandro: 19 n. 8;

Pítia: 44-45; 138-139;

Platão: passim.

Poemas Homéricos: 118 n. 15;

Plateias: 38; 40; 41; 105;

Plateenses: 104-105;

Plistarco: 40;

Plutarco: passim.

Polidoro: 46-47;

Polisperconte: 28;

Pólux: 117;

Pompeio: 98;

Porfírio: 118-119;

Posidipo: 117 n. 13;

Príamo: 33;

Pródico de Ceos: 20;

Protágoras: 135;

Proteu: 115 n. 8; 117 e n. 13;

Pseudo-Hecateu: 119 e n. 18; 122; 124; 125;

Ptolomeu I Soter: 113-114; 116-117; 123 e n. 32 ;
Ptolomeu II Filadelfo: 114-115; 123 e n. 32;

Ptolomeus: 12; 113; 119; 126-127;

Quatrocentos (governo dos): 20 n. 10; 21; 63; 81 n. 30;

Quéreas: 21;

Quérilo: 118 n. 14;

Queroneia: 23; 98; 100; 105;

Quílon: 47 n. 33;

Rhetra (Grande): 10; 38; 45-47;

Rodes: 113 n. 4; 116-117;

Roma: 13; 24; 44; 130 e n. 2;

Romanos: 30;

Roxana: 25; 113;

Sabbath: 122;

Salamina: 17; 38-40; 104-105;

Samaria: 118;

Samos: 20-21;

Samósata: 117;

Segunda Confederação: 22;

Septuaginta: 12; 123 e n. 29; 124; 126;

Sete Maravilhas: 111-118;

Sete Sábios: 46 n. 33;

Sicília: 19; 61-62; 64; 81; 90; 91; 138;

Silas: 130; 139-140;

Simão: 140 n. 27;

Simaquia de Delos: 10; 18; 29; 50-51; 65;

Simaquia do Peloponeso: 29; 50 n. 3 e 5;

Simónides: 15; 26; 37-38; 41;

Siracusa: 52; 61; 101;

Sírios: 118;

Siwah: 121;

Sócion: 135 n. 13;

Sócrates: 63 n. 34; 89; 90; 94-96; 136-138; 141 ;

Sófocles: 73 n. 11; 74;

Sólon: 49; 65;

Solos: 118;

Sóstrato: 116-117;

Susa: 105; 108; 110; 
Taís: 106;

Targélias: 72 ;

Tarso: $12-13$; 110; 127; 129-142;

154 Tebas: 22; 64 n. 38; 79 n. 26;

Telémaco: 34-35;

Temístocles: 37 n. 8; 38-40;

Templo (de Jerusalém): 119; 122;

Teofrasto: 118-119;

Teopompo: 46-47;

Terâmenes: 20-22; 63-64; 101 n. 10;

Termópilas: 37-38; 39; 40;

Terra: 76 n. 18;

Tessália: 39;

Timoleonte: 98;

Tiro: 102 n. 12;

Tissafernes: 20 n. 11;

Torá: 12; 122; 123 e n. 30; 124; 126;

Torre de Faros: 114-118; (vd. Farol de Alexandria)

Trácia: 63;

Trasibulo: 21-22; 63;

Trasilo: 21;

Trinta Tiranos (ou Trinta): 20; 21-22; 64;

Troia: 33; 35; 52 n. 11; 102 e n. 12; 103;

Troianos: 33 n. 1 ;

Tucídides: passim.

Ulisses: 34-35; 112;

Xantipo: 40;

Xenócrates: 90;

Xenofonte: 42; 57; 118 n. 15; 137-138;

Xerxes: 37; 39; 102 n. 13; 105; 118;

Xuto: 75-83;

Zeus: 45; 75-83; 94; 131 n. 4;

Zeus Olímpico: 34;

Zeus Silânio: 46;

Zeus Soter: 117 e n. 13; 


\section{ÍNDICE DE AUTORES ANTIGOS}

\section{Andócides}

3. Sobre a Paz com os Espartanos 3.11-12 e 39: 64 n. 38;

\section{Aristófanes}

Pluto (Pl.)

Schol. ad 954: 70 n. 2;

Rãs (Ra.): 63;

Schol. ad 405: 73 n. 16;

1425: 63 n. 34;

\section{Aristóteles}

[Constituição dos Atenienses]

(Ath.): 49; 71;

26.4: 49-50;

32.2: 20 n. 8 ;

34.1-2: 64 n. 36;

42.2: 72 n. 9 ;

56.3: 71-72;

Politica (Pol.)

1252b: 107 n. 26;

1253a: 30;

1321a31-42: 74;

Retórica (Rh.)

1374a: 135 n. 13;

[Sobre as Virtudes e os Vícios] (VV.)

1251a30-1251b2: 133-134; 135 n. 12;

\section{Arriano}

Anábase de Alexandre

1.16.6: 104 n. 17;

3.16: 105 n. 20;

3.18.12: 106 n. 22;

3.19.5-6: 106 n. 24;
4.8.1-9.4: 109 n. 34;

7.2.9: 110;

Bíblia: 119; 124; 131;

Antigo Testamento

Levítico

25.2: 121 n. 25;

Livro de Daniel: 121;

Novo Testamento

Atos dos Apóstolos: 12-13; 129-131;

138-142;

8.9-11: 140 n. 27 ;

8.18-24: 140 n. 27;

15.1.5: 139

15.7-11: 139;

15.35-21.16: 138-139;

16.16: 139-140;

16.16-40: 130;

16.19-21: 140;

16.35-39: 129 ;

17.22-23: 141-142;

18.12-13: 140-141;

19.19: 140 ;

19.21: 130 n. 2

22.23-29: 129;

22.28: 129;

23.11: 130 n. 2 ;

23.27: 129;

26.32: 130 n. 2;

Carta a Arísteas: 124-125; 126;

Clearco de Solos

Sobre o sono: 118;

1 Os trabalhos cuja autoria é dúbia ou disputada encontram-se colocados entre parêntesis retos []. Os parêntesis curvos () são usados para assinalar as convenções através das quais os títulos das obras são geralmente abreviados pela comunidade científica. 


\section{Cúrcio Rufo}

História de Alexandre Magno

8.1.19-2.10: 109 n. 34;

8.5.5-6.1: 109 n. 35;

156

\section{Demóstenes}

1. Primeira Olíntica

1.17: 100 n. 7;

1.24: 100 n. 7 ;

21. Contra Mídias

21.45-48: 135 n. 12;

26. [Contra Aristogíton II]

26.5: 87;

60. [Discurso Fúnebre]: 53-54;

60.4: 54-55; 58; 81 n. 31;

\section{Diodoro Sículo}

Biblioteca Histórica

1.9.3: 51-52;

12.39.2: 135 n. 13;

13.38.2: 20 n. 9;

13.107.4: 64 n. 38;

17: 97 ;

17.74.3: 106 n. 24;

18.66.4: 93 n. 19;

40.3: 119;

40-3.4: 119 n. 17 ;

\section{Diógenes Laércio}

Vidas e doutrinas dos filósofos ilustres

2.12.4-8: 135 n. 13;

2.40: 137 n. 20 e 138;

6.63: 31 n. 21;

Eliano

História Vária $(V H)$

12.49: 89 n. 8;

\section{Ésquilo}

Oresteia: 68; 69;

Agamémnon (Ag.): 34;

$$
\text { 11: } 34 \text { n. 3; }
$$

\section{Ésquines}

1. Contra Timarco

1.15-17: 135 n. 12 ;

\section{Estrabão}

Geografia

15.3.6: 106 n. 22;

17.1.6 e 9: 115-117;

\section{Eurípides}

Íon (Ion): 11; 54 n. 17; 65; 68; 75-83; 10: 75 ;
20-21: 75;

29-30: 76 ;

57-73: 76-78;

58-64: 79 n. 25;

109-111: 78;

136: 78;

137-139: 78;

182-183: 78;

266-270: 78 n. 23;

267: 78 n. 23 ;

289-293: 78-79;

309-311: 78 n. 21;

472-491: 77 n. 20;

537: 80 ;

542: 80;

545: 80;

556: 80;

559: 80;

585-594: 80-81;

656: 81;

660: 81;

1295-1303: 81 n. 31;

1299: 81 n. 31 ;

1539-1545: 82;

1571-1572: 82;

1595-1603: 82-83;

Medeia (Med.): 68; 69;

\section{Flávio Josefo}

Antiguidades Judaicas

11.304-346: 121;

11.337-339: 121-122; 125 n. 36;

12.107-108: 124-125;

14.117: 125-126;

Contra Ápion

1.172-173: 118 n. 14

1.176-182: 118 ;

1.186-189: 122 n. 28;

1.186-204: 119-121;

1.189: 122-123;

1.190-192: 119-121;

Hecateu de Abdera

História do Egipto: 119;

(Pseudo)-Hecateu de Abdera

Sobre os Judeus: 119-120;

\section{Heródoto}

Histórias

1.4-5: 102 n. 13 ;

1.65.2-4: 44-45;

1.134: 108 n. 29; 
1.144-147: 52 n. 10 ;

2.104.2-3: 118;

5.22.2: 100 n. 7 ;

7.140: 36 n. 6 ;

7.141: 39 n. 14

7.157.1: 36 n. 7 ;

7.161: 52 ;

7.173.1: 36;

7.220: 36 n. 6 ;

7.228.2: $37-38$

8.2: 37 n. 8 ;

8.42: 39 n. 13 ;

8.71: 39 n. 13 ;

8.142.4: 36 n. 7 ;

9.7 2 2: 40 ;

9.58-70: 40 n. 16 ;

\section{Hiperides}

6. Discurso Fúnebre: 53-54;

\section{Homero}

Ilíada (Il.)

1.33-42: 131 n. 4;

2: 33 ;

2.546-548: 53;

2.581-590: 34;

3.146-160: 33 n. 1;

16.231-248: 131 n. 4;

Odisseia (Od.)

4.65-75: 34;

4.120-136: 34-35;

4.168-182: 35;

4.354-360: 115;

\section{Isócrates}

4. Panegírico

4.25: 53 n. 14;

\section{Justino}

12.7.1-3: 109 n. 35;

\section{Lísias}

2. [Discurso Fúnebre]: 53-54;

13. Contra Agorato

13.14: 64 n. 38;

\section{Luciano de Samósata}

Sobre a forma de escrever história 62: 117 n. 12;

\section{Onesícrito}

FGrHist 134 F 17a36-7: 99 n. 5;

\section{Pausânias}

1.18.8: 101 n. 8;

3.16-6: 45 ;

\section{Píndaro}

Fragmentos (Snell)

77: 38 e n. 11 ;

Platão

Apologia (Ap.)

Êtifron (Euthphr.)

7a: 132-133;

Leis (Lg.): 99 n. 5; 691e-692a: 46 n. 30;

Menéxeno (Mx.): 54 237a-238d: 58 n. 26; 237b-237c: 58-59;

Protágoras (Prt.) 325c-326d: 133 n. 7; República $(R$.) 427b-c: 132 n. 5;

Sofista (Sph.)

247c: 52 n. 8 ;

248c: 52 n. 8 ;

\section{Plutarco}

Moralia

Ditos dos Lacedemónios

(Apophth. Lac.)

227b: 45 n. 27 ;

Sobre a fortuna ou virtude de

Alexandre Magno (De Alex. fort.

aut virt.)

328a-e: 99;

328e: 108 n. 32;

Sobre a glória de Atenas

(De gloria Ath.)

348d-349b: 73 n. 15;

Vitae: 98-99;

Agesilau (Ages.)

15.4: 105;

Ágis (Agis)

4.2: 43 n. 21;

Alcibiades (Alc.)

1.3: 90;

4.1-4: 90;

6.1-5: 90;

7.4-5: 90;

17.1-4: 90 n. 9;

17.5: 90;

Alexandre (Alex.)

1.1-2: 98-99;

5.8: 102 n. 12;

15.8: 103 n. 14;

16.3: 103 n. 15; 
16.13-14: 103;

16.17-19: 104;

24.10-14: 102 n. 12 ;

34.2-3: 104-105;

158

37.7: 105 n. 21;
38: 106 ;

47.5-6: 109;

50-51: 109 n. 34;

54.2-55.4: 109 n. 35;

70.3: 108 n. 31;

71.3: 109 n. 33;

Cleómenes (Cleom.)

10: 43 n. 21;

Demétrio (Demtr.)

24.3-4: 29;

26: 29 n. 20;

Emílio Paulo (Aem.)

1.1: 98;

Fócion (Phoc.)

1.1-6: 89 n. 4;

3.2-5: 90 n. 11 ;

4.2: 90;

6.5-7: 91 n. 13;

8.1-2: 89 n. 7 ;

27.5: 93 n. 18;

28.1-2: 91-92;

34: 28;

34.3: 93-94;

36-37: 94;

37.4: 94 n. 21;

38.5: 94-96;

Licurgo (Lyc.): 43; 44;

1.1: 43;

1.2-6: 43-44;

1.7: 44;

5.10-14: 46;

6.1-2: 45-47;

7-8: 45-47;

13.1-2: 45 n. 27 ;

Lisandro (Lys.)

14.8: 64 n. 38;

Nicias (Nic.)

23: 135 n. 13;

Péricles (Per.)

32.1: 136 n. 16;

32.2: 136;

Temístocles (Them.)

8.2: 38 n. 11 ;
Porfírio

Sobre a abstinência

2.26: 118-119;

\section{Simónides}

(West)

15: 15 ;

\section{Sócion}

Sobre a Sucessão dos Filósofos:

135 n. 13 ;

\section{Tucídides}

Guerra do Peloponeso

1.2.5: 52 n. 11;

1.12.3: 52 n. 11 ;

1. 89-118: 17 n. 5;

1.96: 50 n. 4 ;

2.17.1-3: 60 n. 29 ;

2.35-46: 53; 59;

2.36.1-2: 59-60;

2.41.1: 18 n. $6 ; 59$ n. 28 ;

2.47-54: 60 n. 30 ;

2.60.2-3: 86-87;

6.1: 61 n. 32;

6.6: 61 n. 32 ;

6.8-26: 61 n. 32;

6.28.2: 141 ;

8.68.1-2: 20 n. 8;

8.68.4: 20;

8.97.3: 20 n. 9;

\section{Xenofonte}

Constituição dos Lacedemónios (Lac.)

14: 42;

Helénicas (Hell.)

1.6.28-7.35: 63 n. 34;

2.1.28-32: 64 n. 36;

2.2.16-23: 64 n. 37;

2.2.20: 64 n. 38;

2.3.30-34: 20 n. 10;

2.3.47: 20 n. 10;

Memoráveis (Mem.)

1.1.1: 137-138;

Sobre os recursos (Vect.)

2.6: 57; 
(Página deixada propositadamente em branco) 


\section{Série Investigação}

Imprensa da Universidade de Coimbra

Coimbra University Press

2012

Obra publicada

com a Coordenação

Científica

Gintro de Estumos

CLÁSSICOS E HUMANiSTICO

$+1$ 